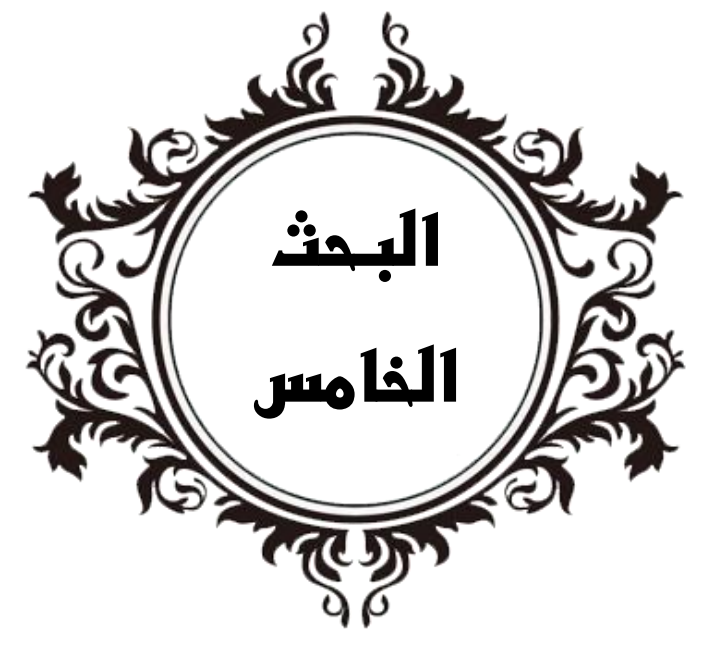

$\square$

فمالية برنامج ذدريبى مقترح لننمية إبعاد الأمن

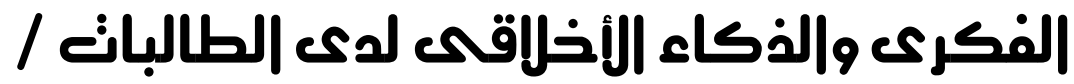

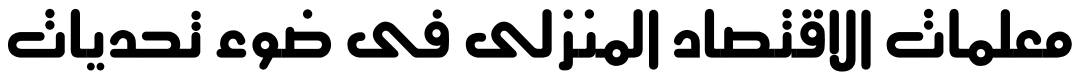
|التربية المسنقبلية

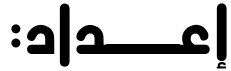

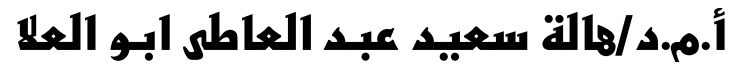

أستاذ مسـاعد منـاهـج وطرق تدريس الاقتصساد المنزلى إنى

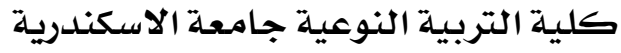





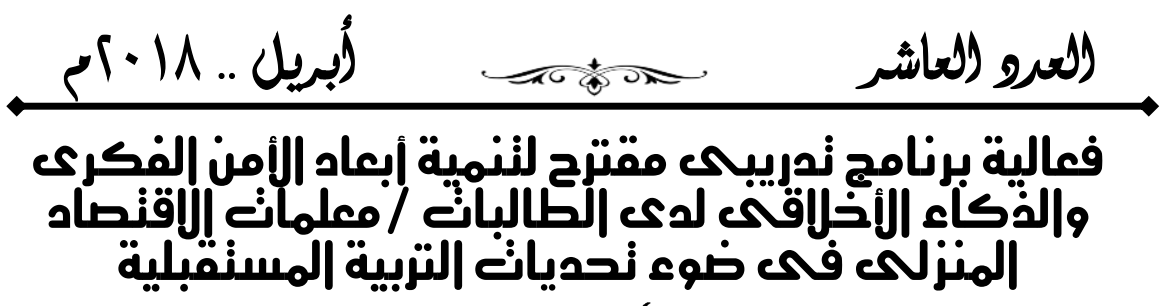

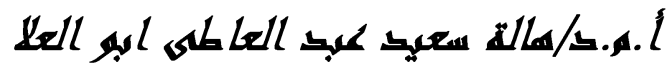

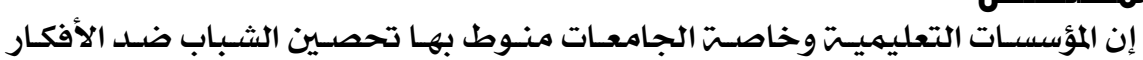

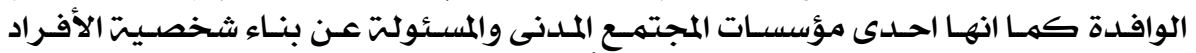

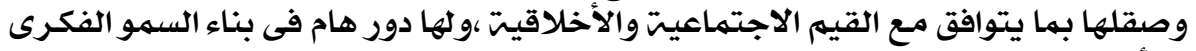

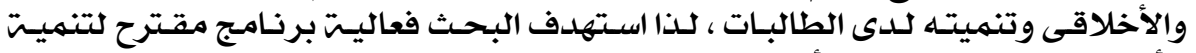

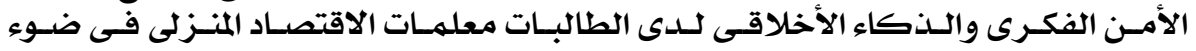

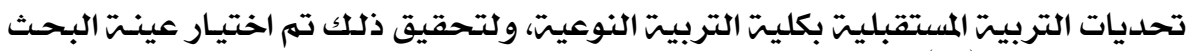

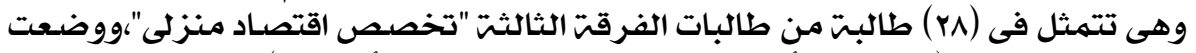

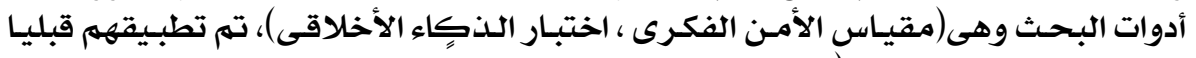

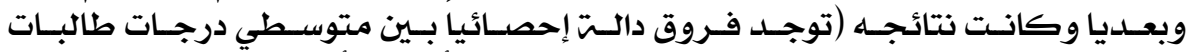

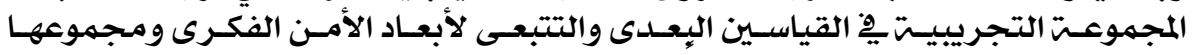

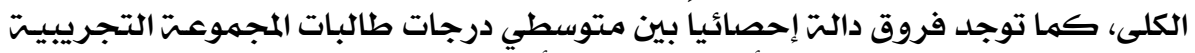

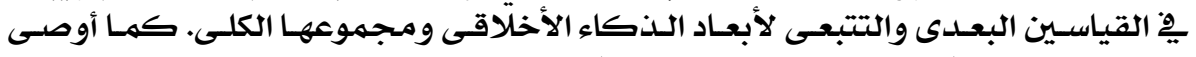

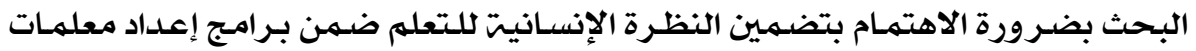

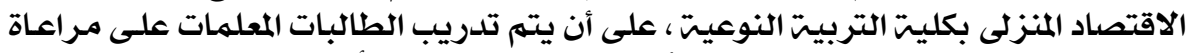

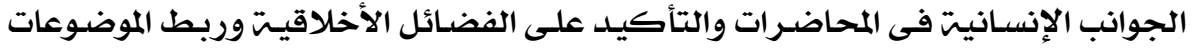

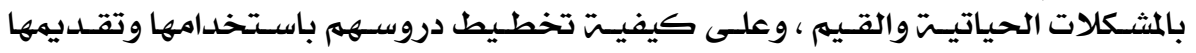

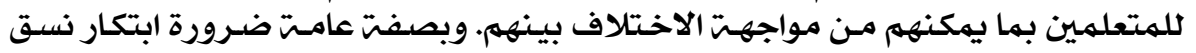

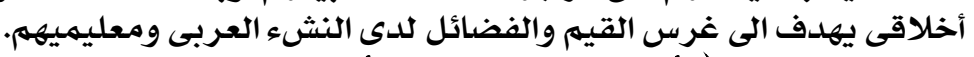

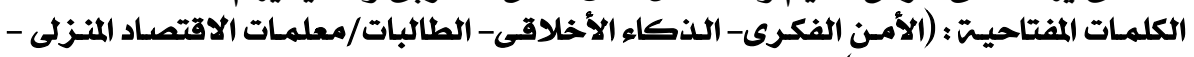
تحديات التربيت المستقبلينة).

Effectiveness of a proposed training program for Developing Dimensions Intellectual Security and Moral intelligence for Students Teachers of Home Economies In light of Challenges of Dr. Hala Said Abdel Aati Abou El Ela

\section{Future Education}

\section{Abstract:}

The educational institutions, especially universities, are charged with immunizing young people against imported ideas. It is also one of the institutions of civil society, which is responsible for building the personality of individuals and refining them in accordance with social and moral values, and has an important role in building the intellectual and moral highness and development of the students. The intellectual security and moral intelligence of the female students of the domestic economy in the light of the challenges of future education in the Faculty of Specific Education. In order to 
achieve this, the research sample was chosen. It consisted of (28) female students from the third division "Home Economics" A research (the measure of intellectual security, the test of moral intelligence), applied before and after the results (There are statistically significant differences between the mean scores of the experimental group's students in the dimensional and the follow-up dimensions of the intellectual security dimensions and their totality, and there are statistically significant differences between the average scores of the experimental group's students in the dimensional and follow-up dimensions of the dimensions of moral intelligence and its total sum. To learn within the programs of preparing the parameters of the home economy in the Faculty of Specific Education. The students should be trained to take into account the human aspects of the lectures and to emphasize moral virtues and to relate the subjects to the problems of life and And how to plan their lessons using and presenting to learners so that they can face the difference between them In general, the need to devise an ethical format aimed at instilling values and virtues among Arab youth and their teachers.

Key words: (intellectual security- moral intelligence -Students Teachers of Home Economies -Challenges of Future Education).

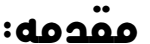

تعيث البشريت اليوم مأزقا حضساريا خطيرا في ظل عولمت تسلطيت طغت إنس

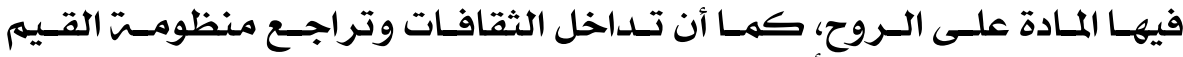

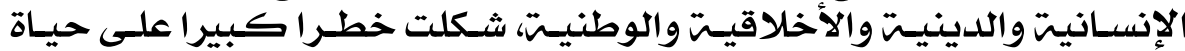

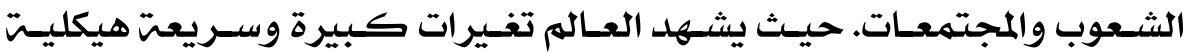

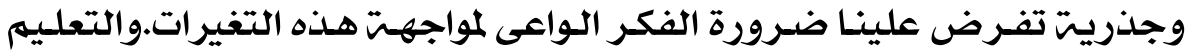

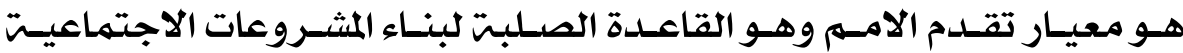

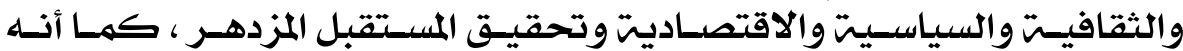

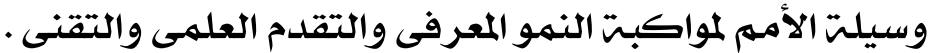

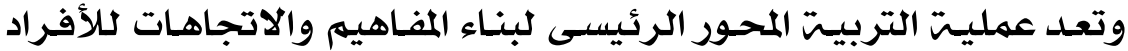

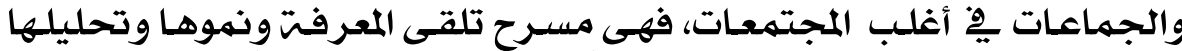

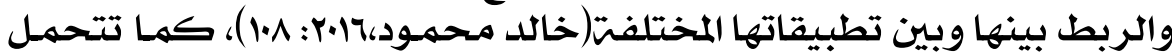

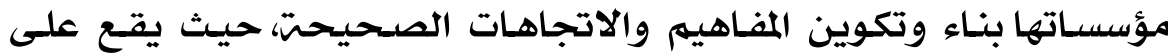

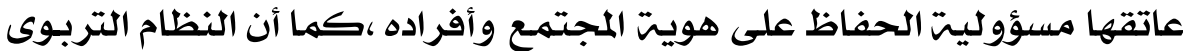

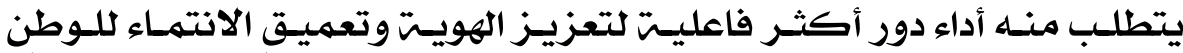

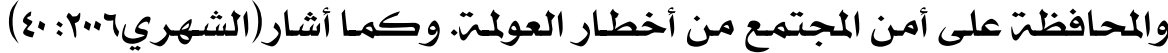




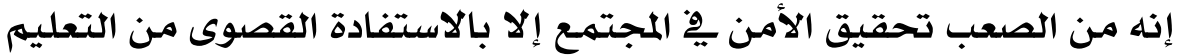

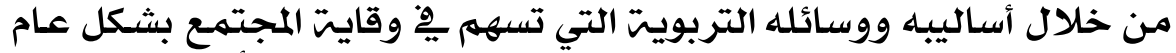

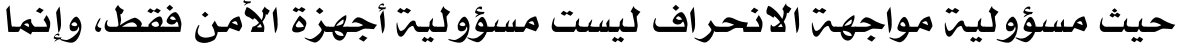

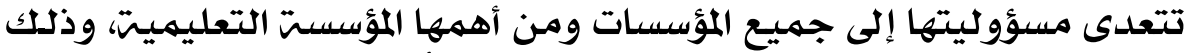

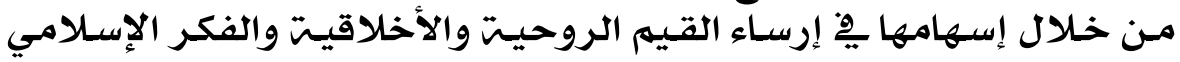

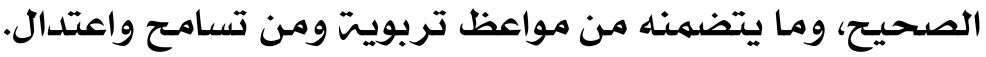

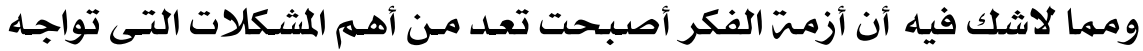

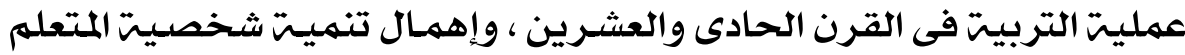

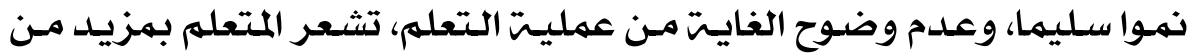

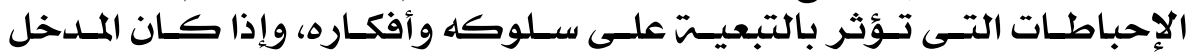

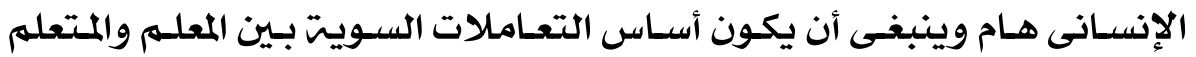

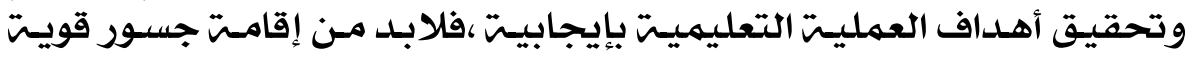

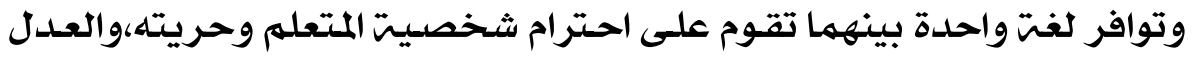

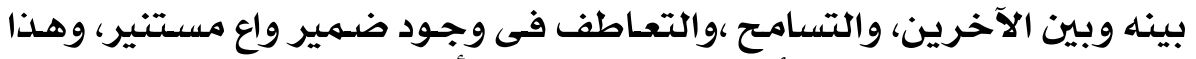

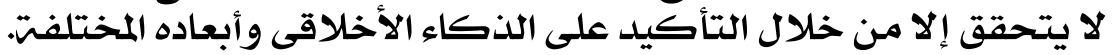

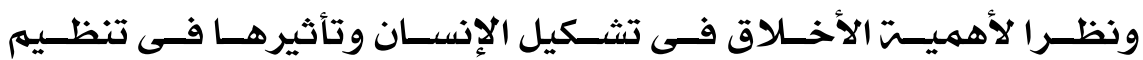

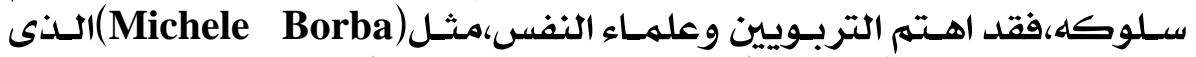

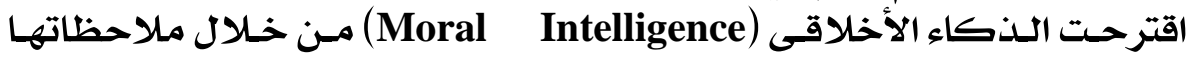

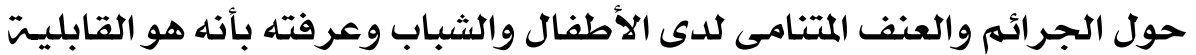

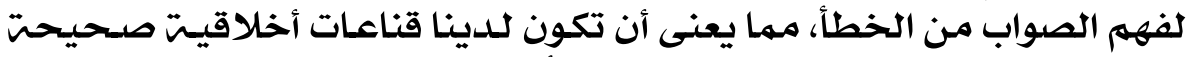

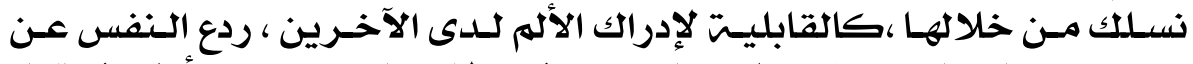

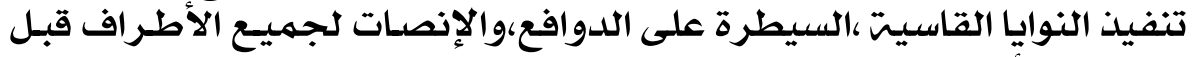

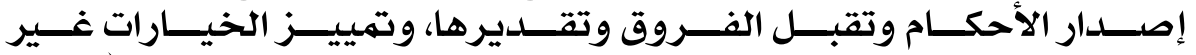

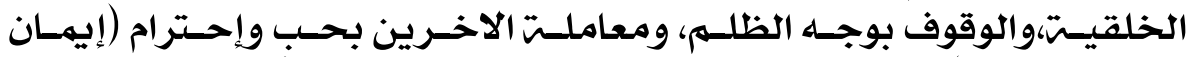

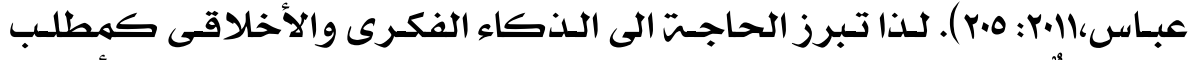

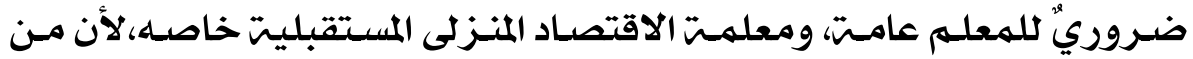

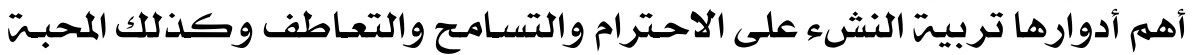

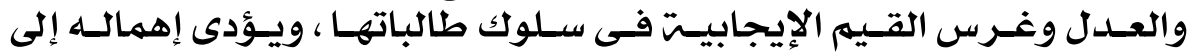

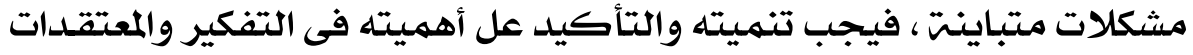
والسلوك.

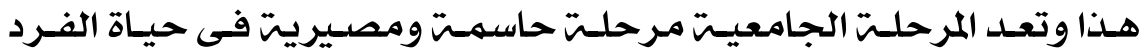

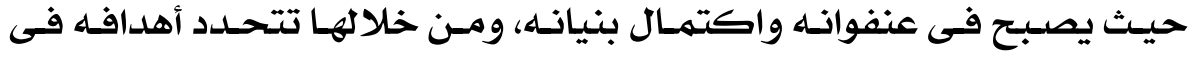

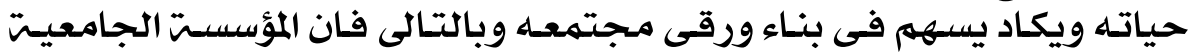

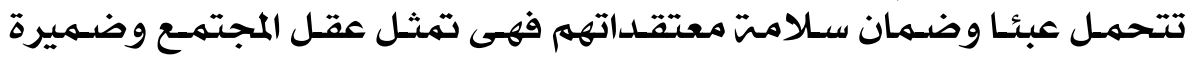




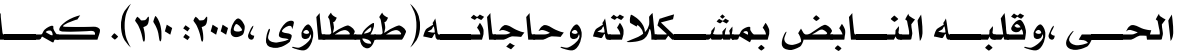

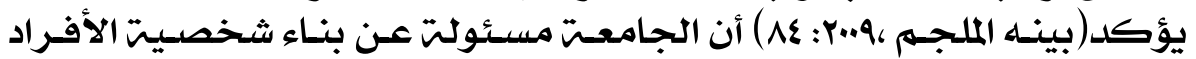

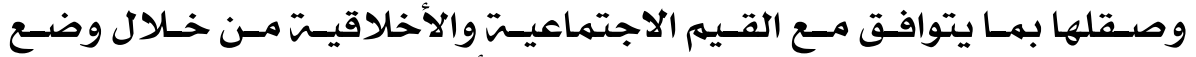

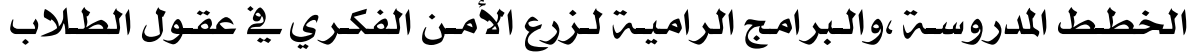

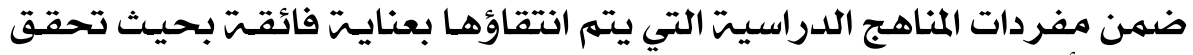

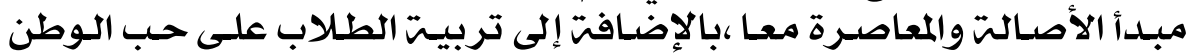

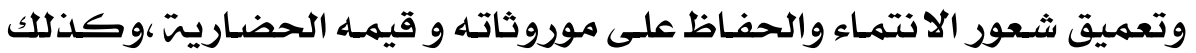

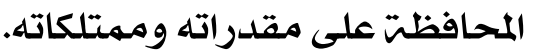

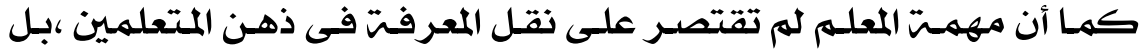

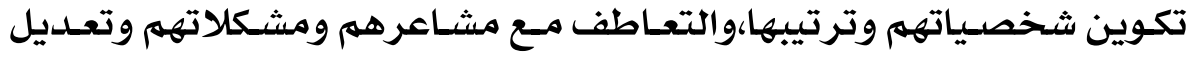

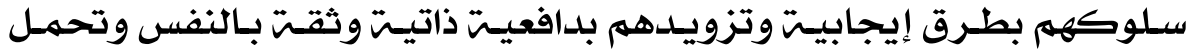

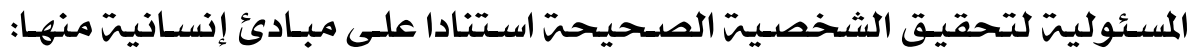

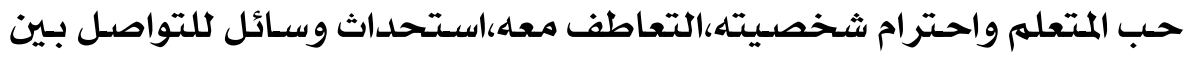

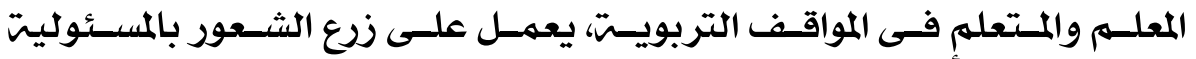

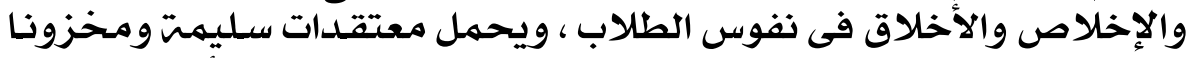

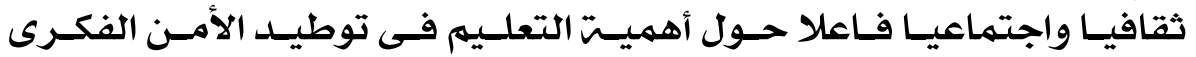

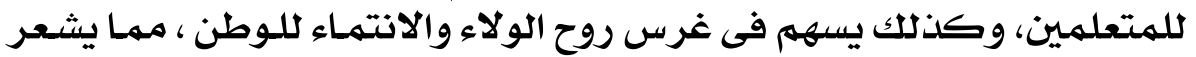

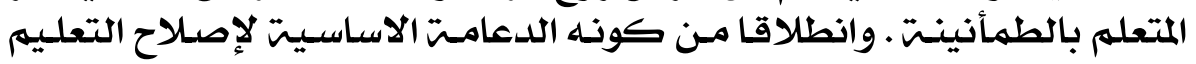

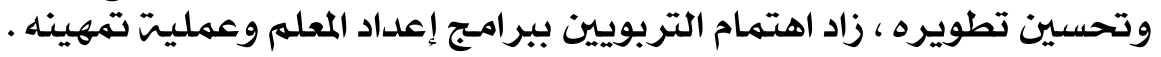

\section{• الإحساس بمهنهُة البحثه :}

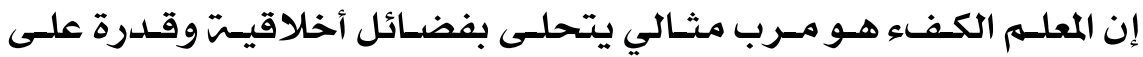

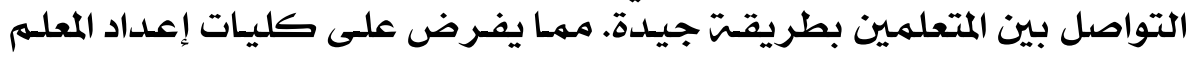

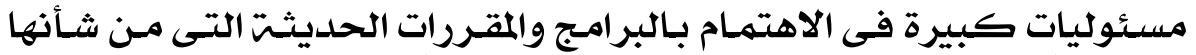

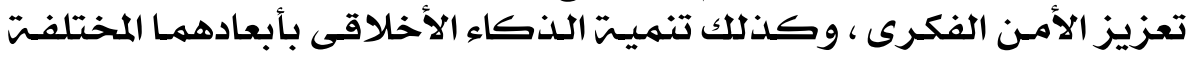

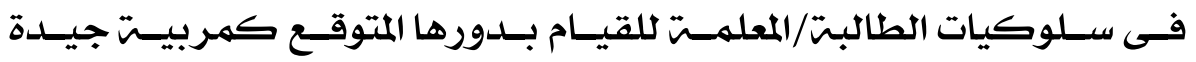

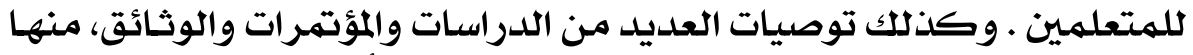

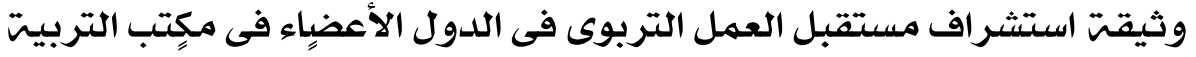

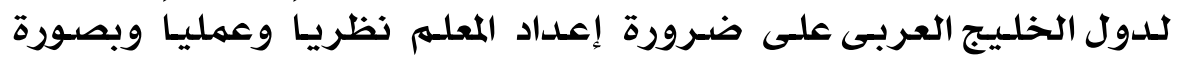

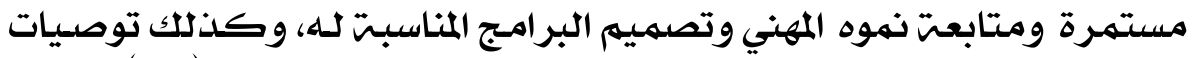

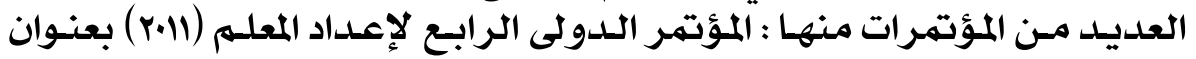

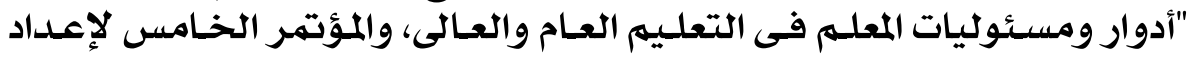

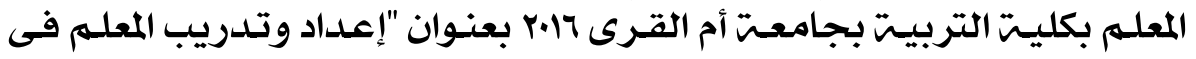

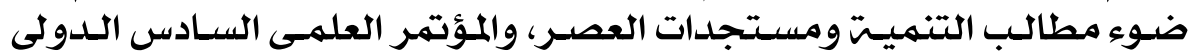

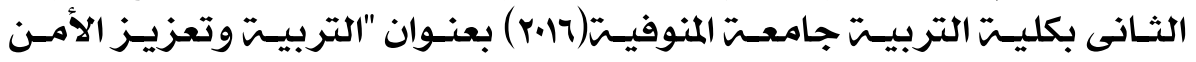




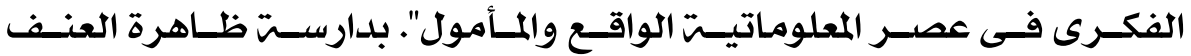

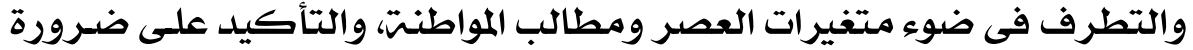

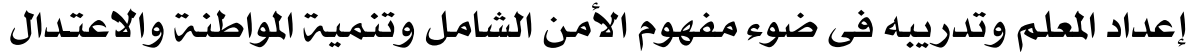

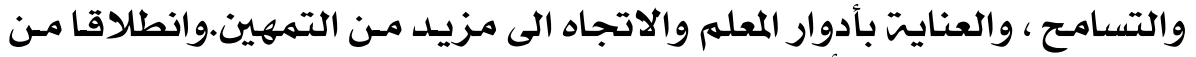

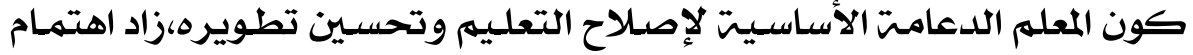

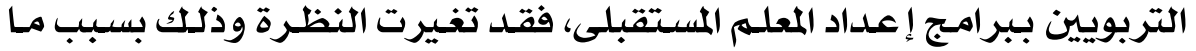

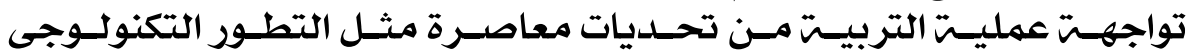
والثورة المعلوماتيت.

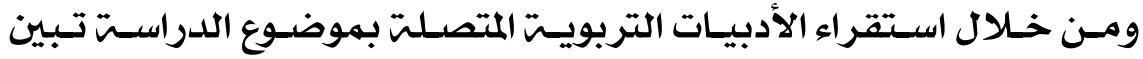

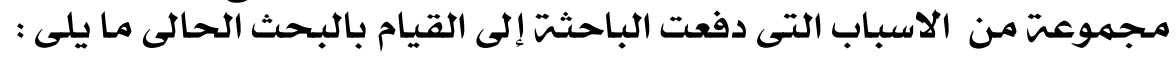

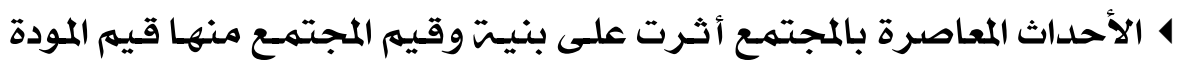

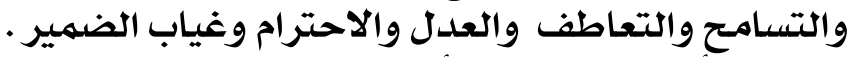

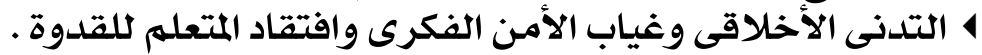

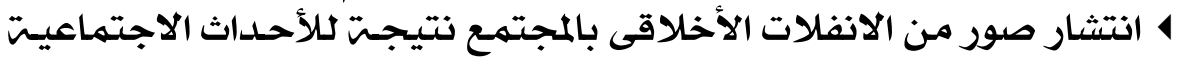

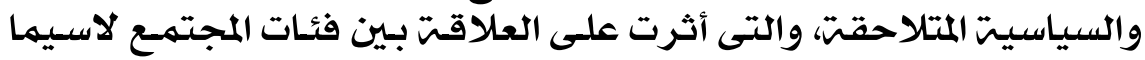
المعلهم والمتعلهم. 4 ضعف العلاقات الجيدة بين المعلم والمتعلهم التى تقـوم على المودة والتعـاطف

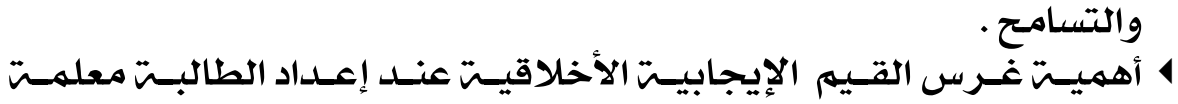

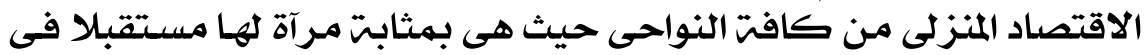

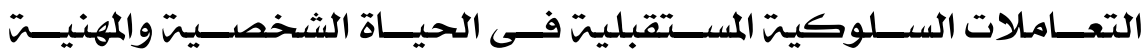

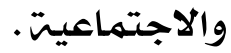

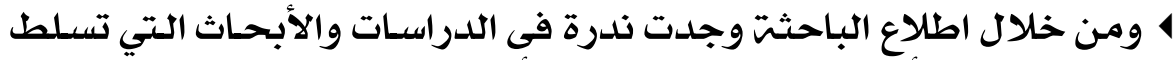

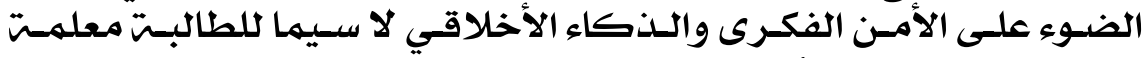

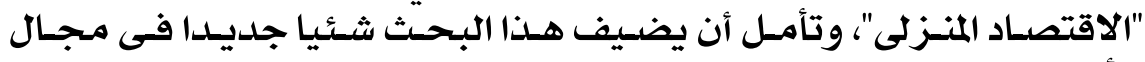

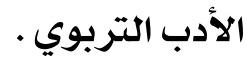

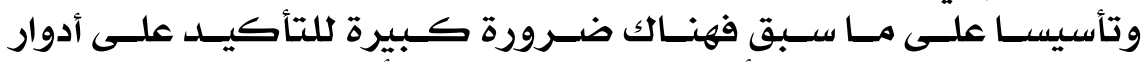

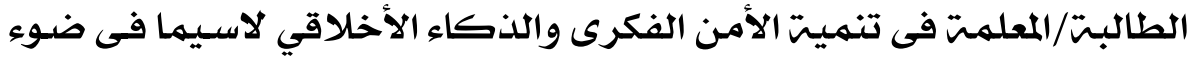

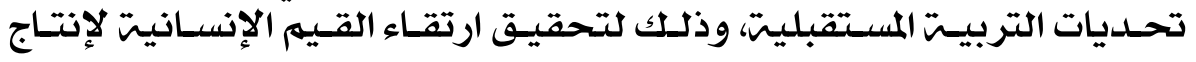

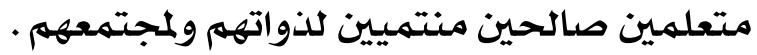

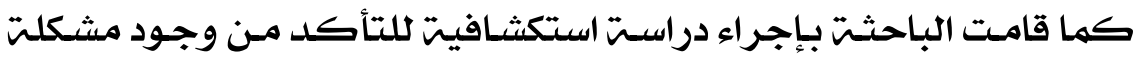

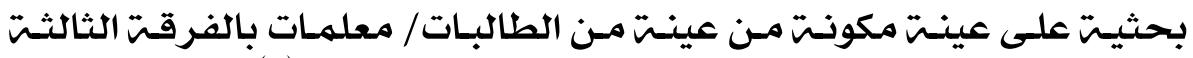

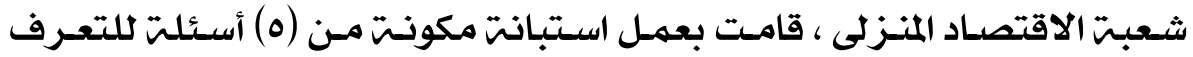

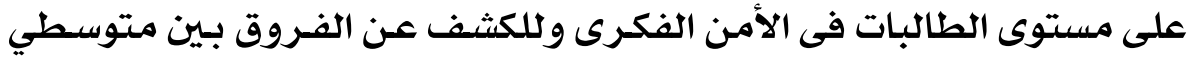




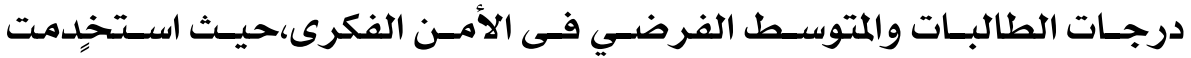

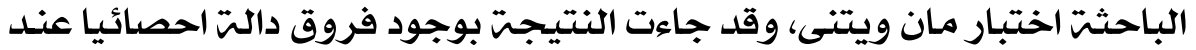

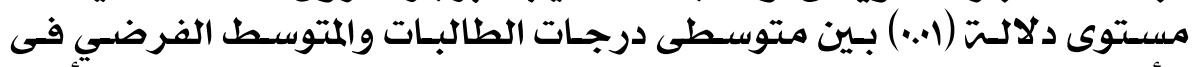

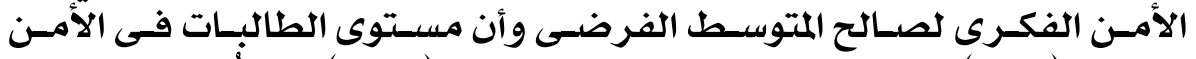

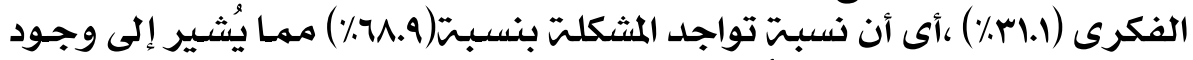

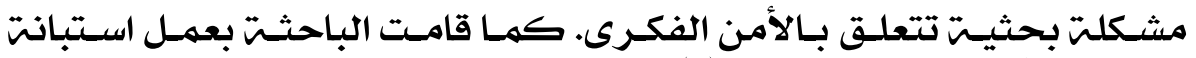

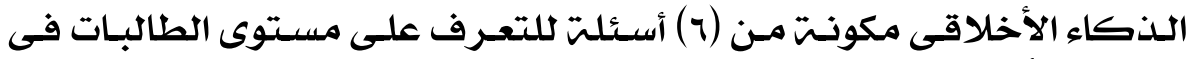

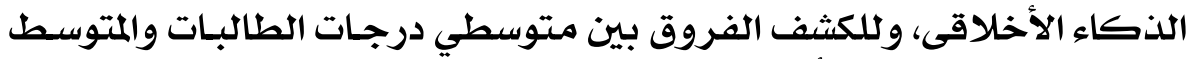

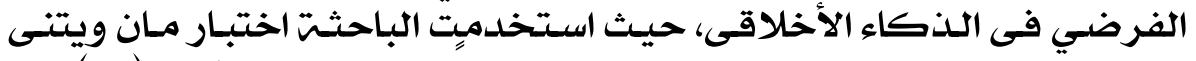

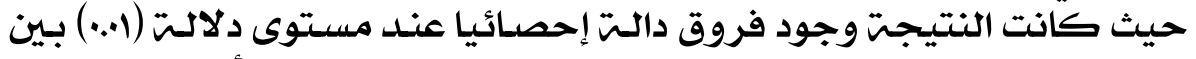

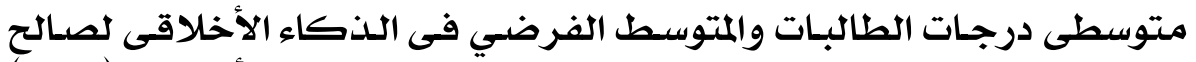

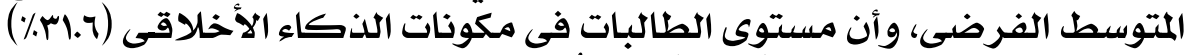

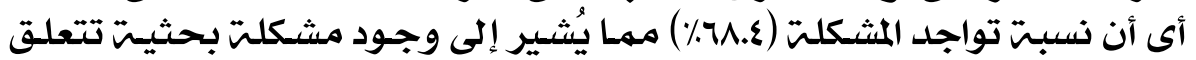

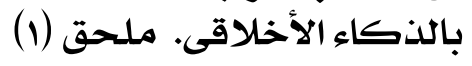

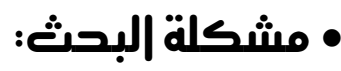

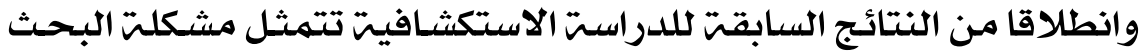

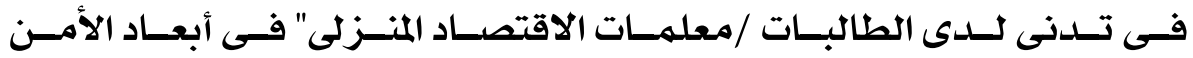

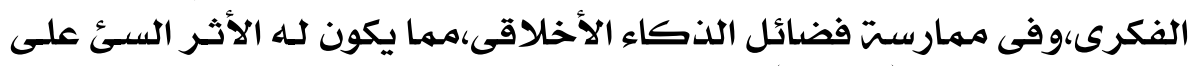

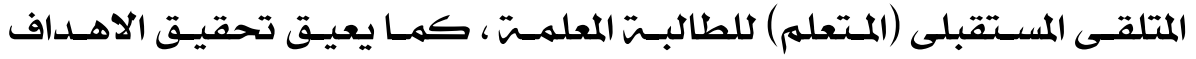

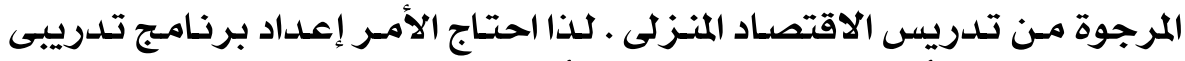

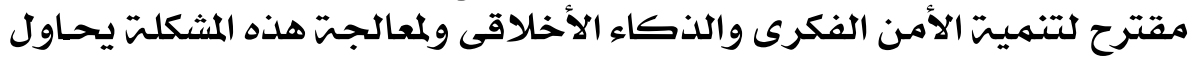

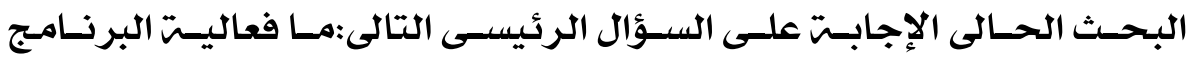

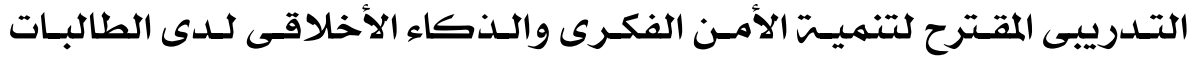

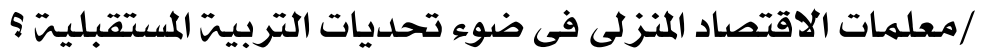
ويتفرع منـه التساؤلات الفرعيت الاتيتي :

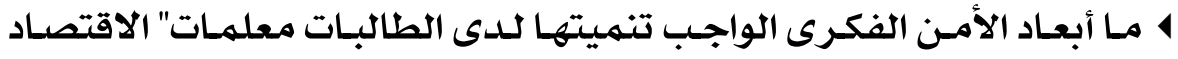

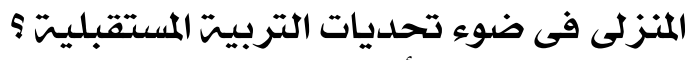

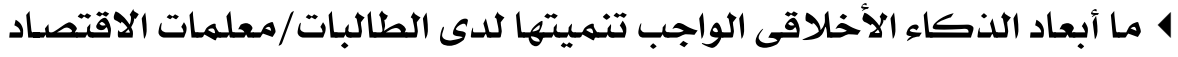

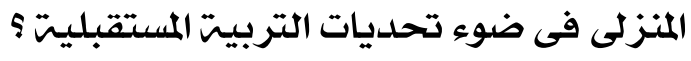

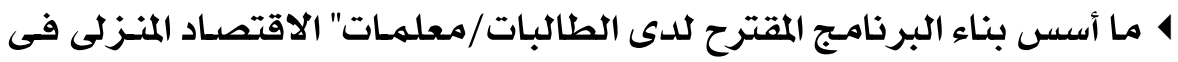

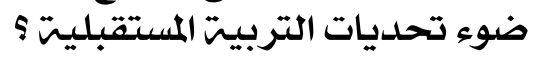

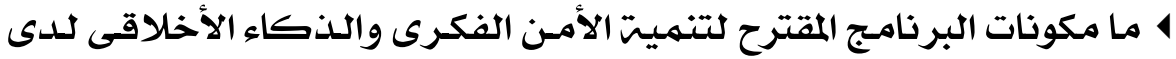

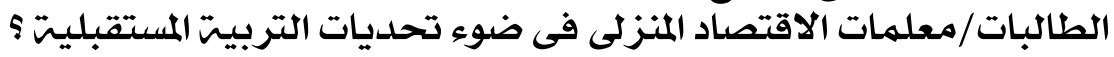




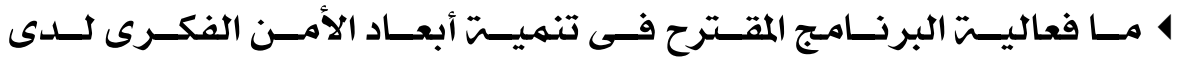

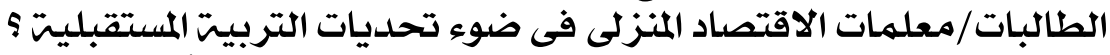

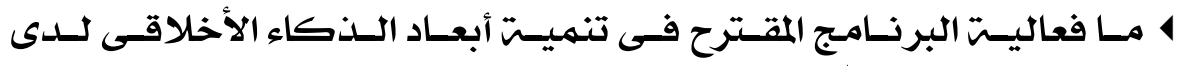

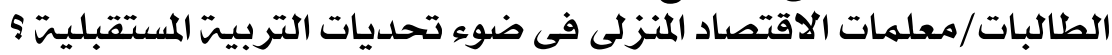

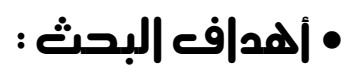
هدف البحث الى:

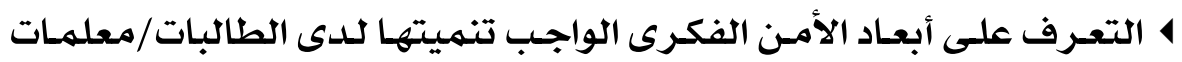

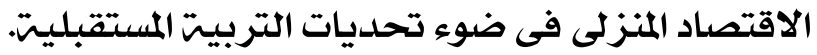

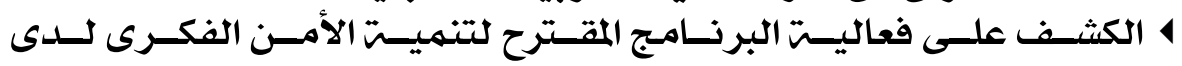

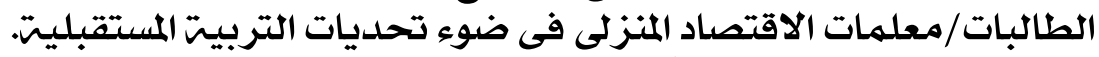

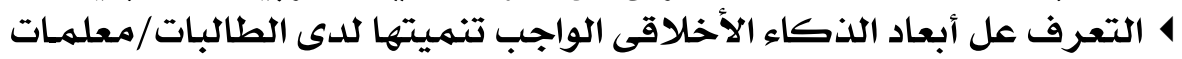

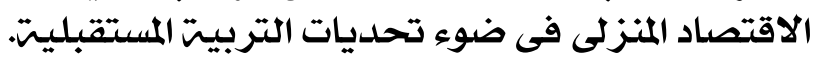

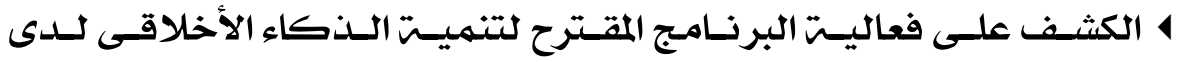

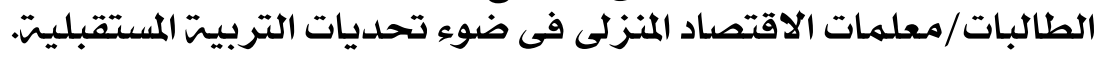

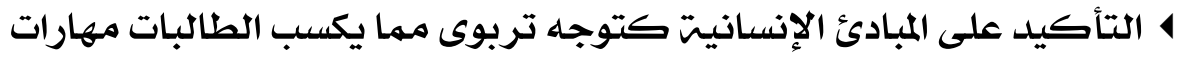

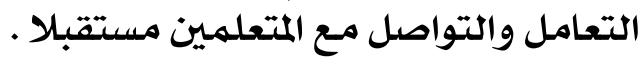

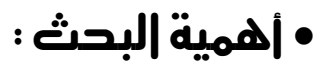
قد يفيد البحث الحالى ف الآلى : • الإلهمية النظرية :

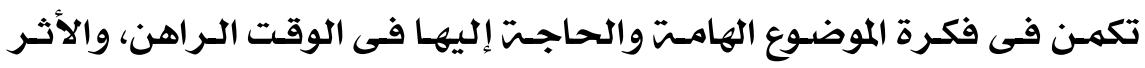

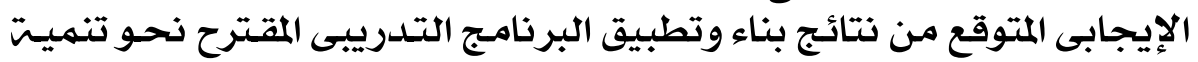

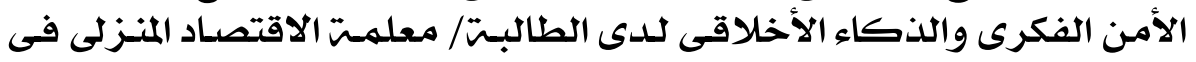

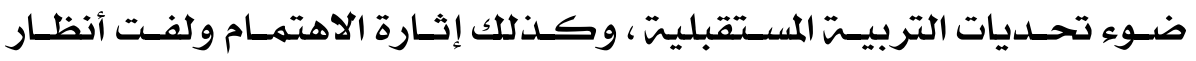

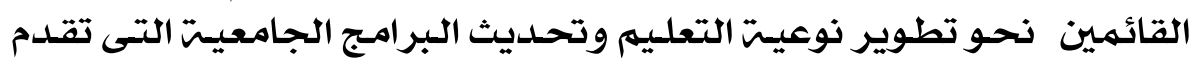

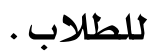

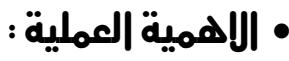

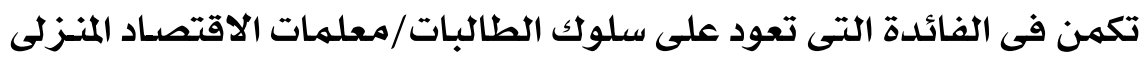

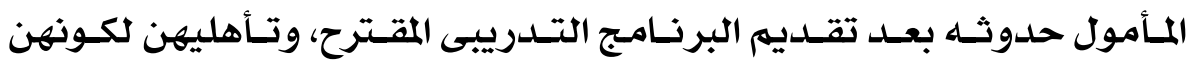

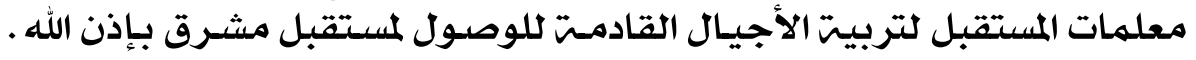

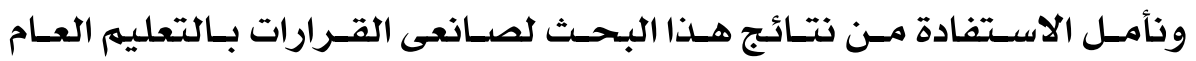

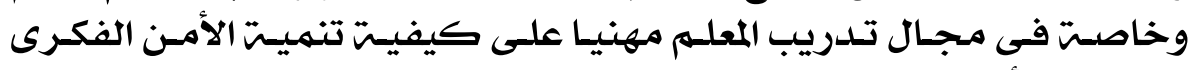

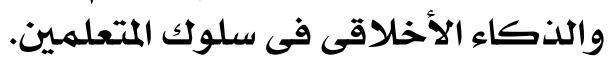




\section{• حمود البحث:}

• حمود موضوعيه وبشرية:

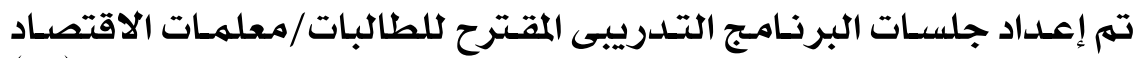

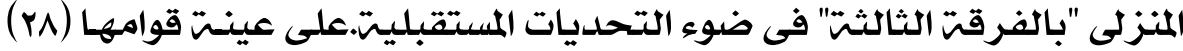

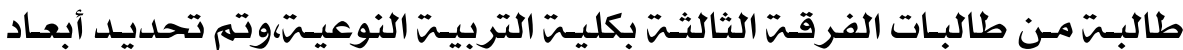

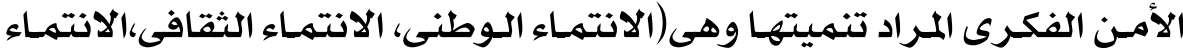

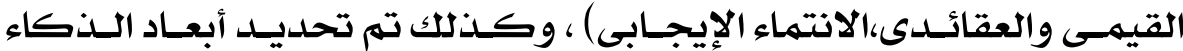

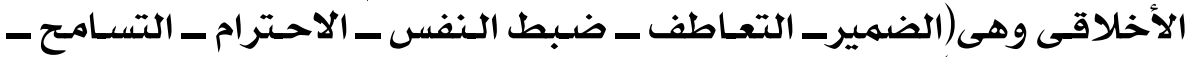

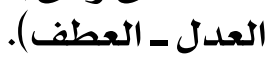

\section{• حدود مكانيه وزمانية:}

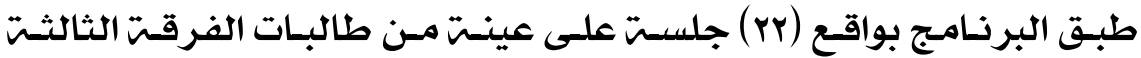

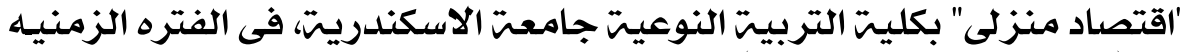

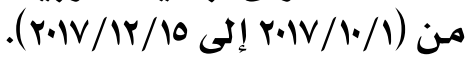
• منهج البحثة :

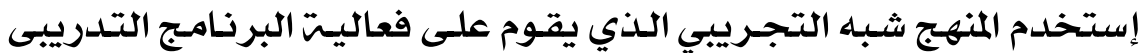

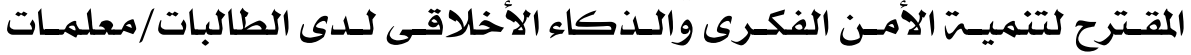

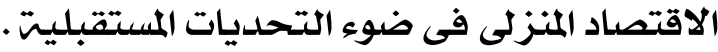
• فروض البحث: أنى

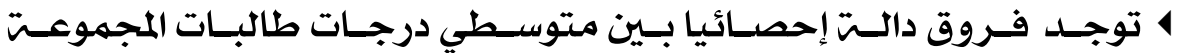

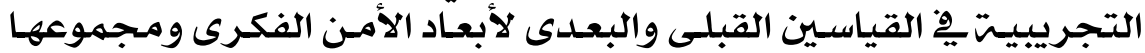
الكلى لصالح القياس البعدئ.

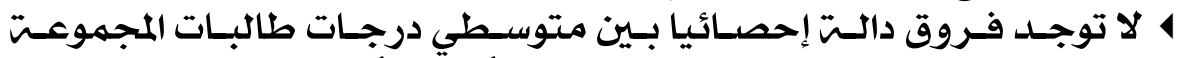

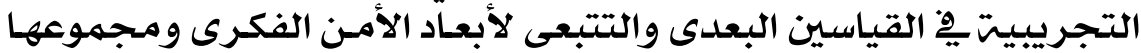
الكلى.

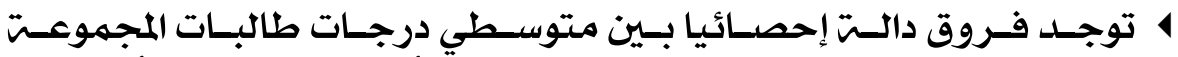

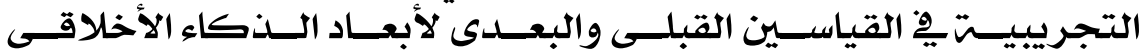

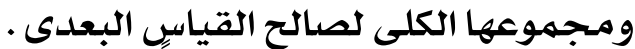

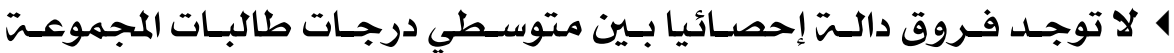

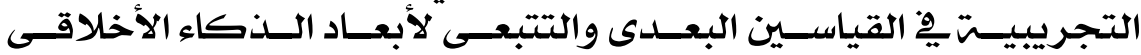
ومجموعها الكلى.

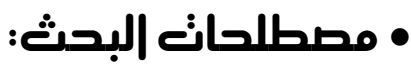

وضعت الباحثت التعريفات الإجرائيت لمصطلحات البحتحث وهى : Y. 


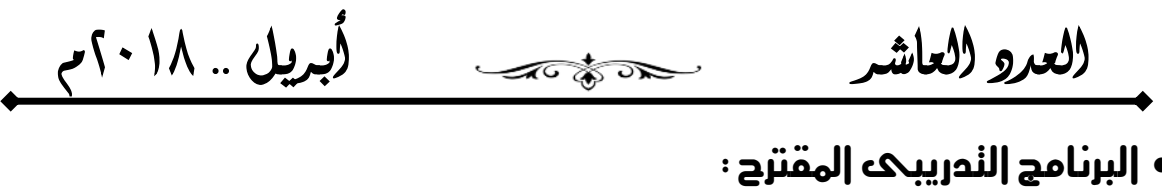

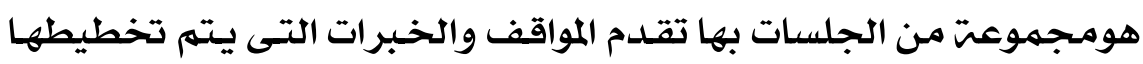

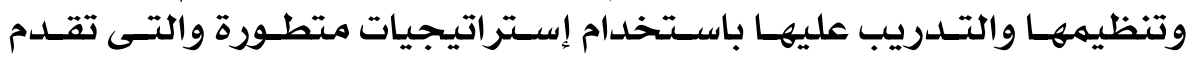

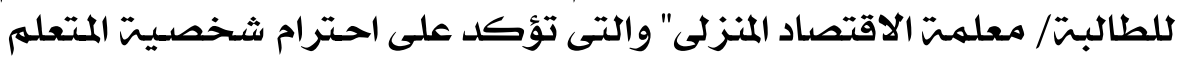

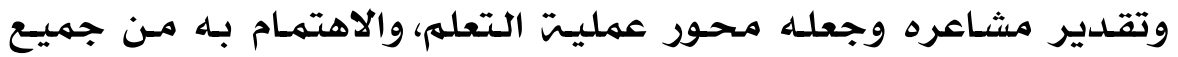

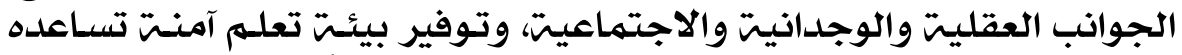

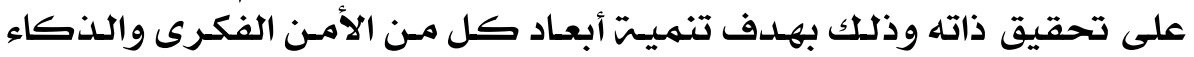

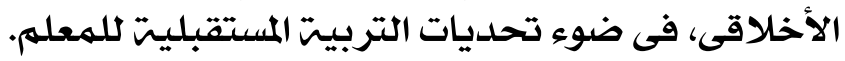

\section{• الأمن الفكرى :}

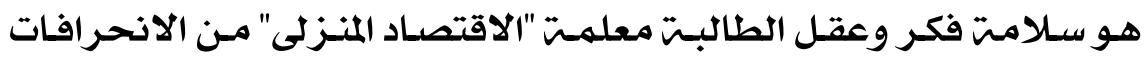

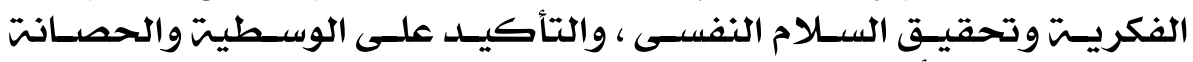

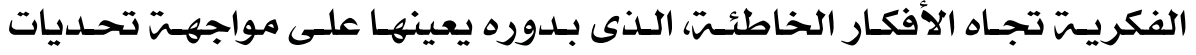

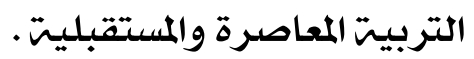

\section{• الفكاء الأخلاقه:}

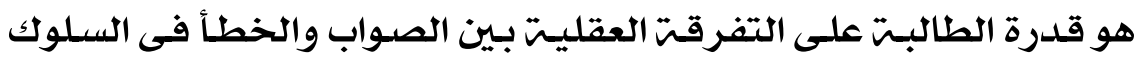

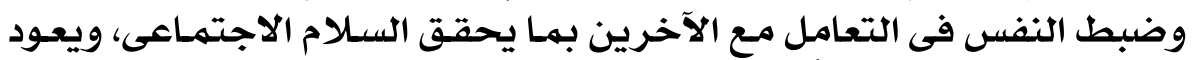

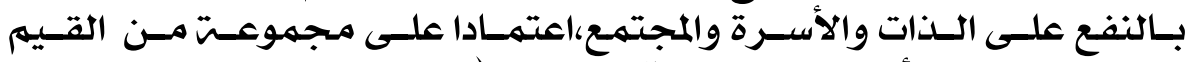

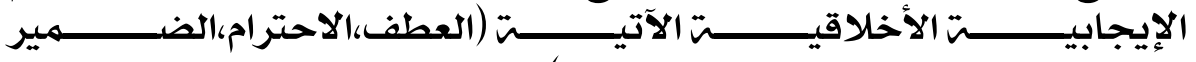

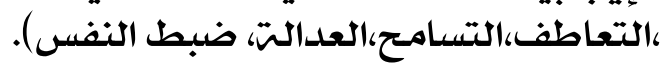

• نحديانه التزبية المسنْقبلية:

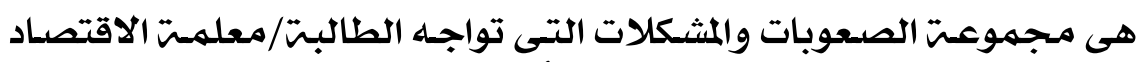

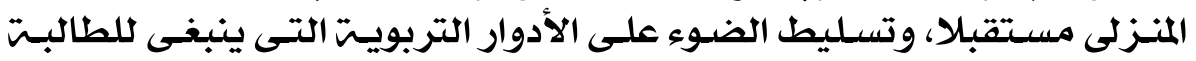
القيام بها مستقبليا.

\section{• أدوار المعلمة المسنْقبلية:}

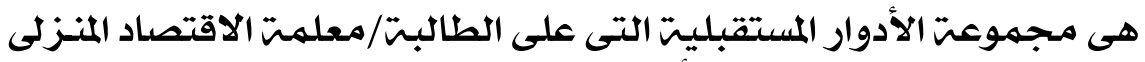

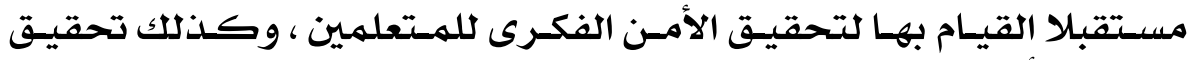

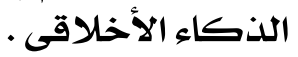

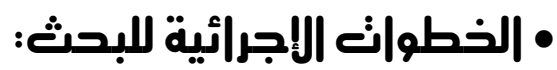

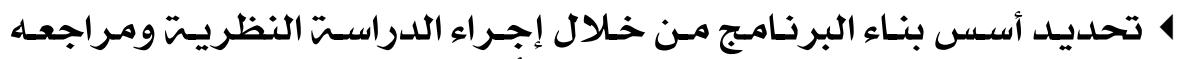

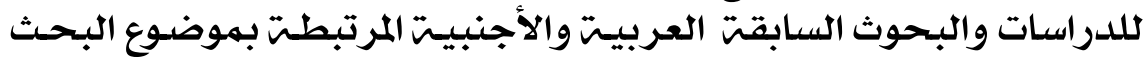

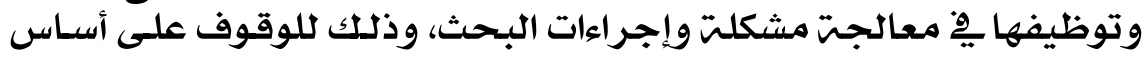

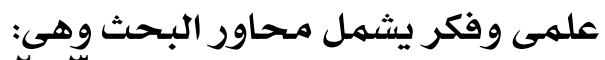
$r \cdot r$ 


\section{(أبريل .. 1 ا - امي}

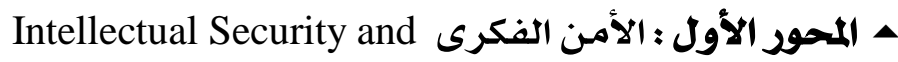

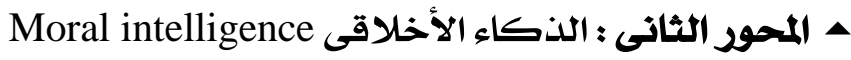

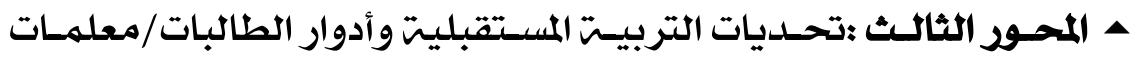

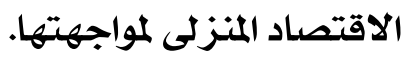

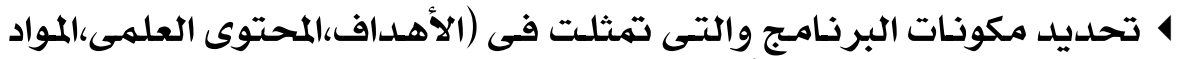

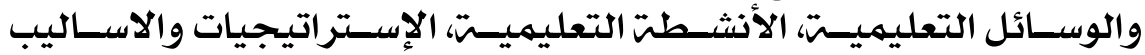

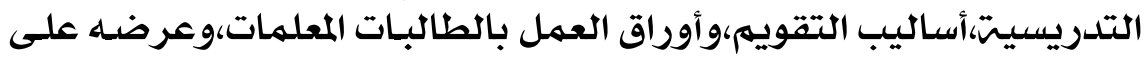

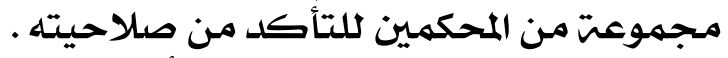

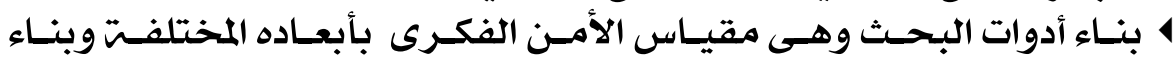

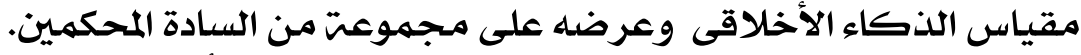

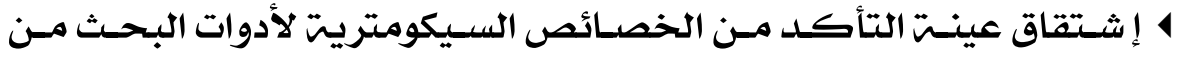

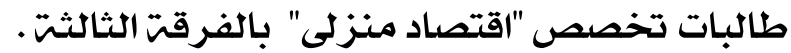

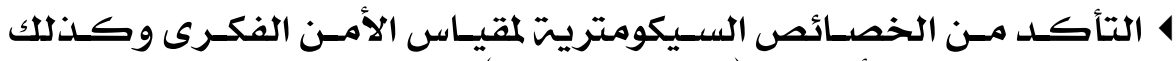

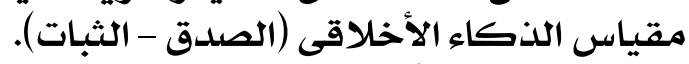

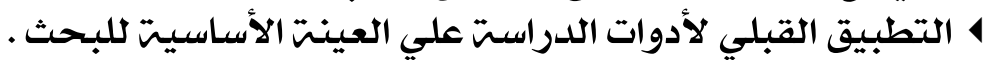

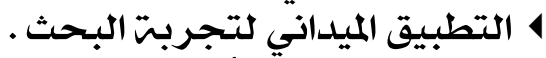

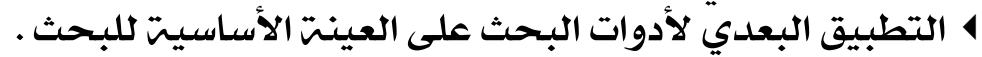

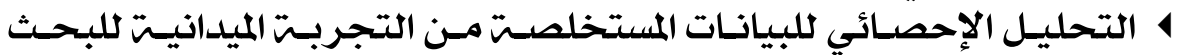

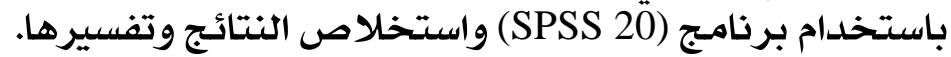

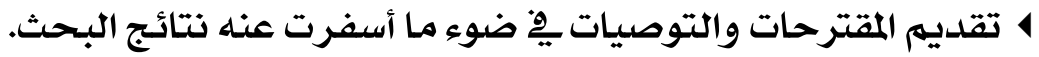

\section{• إلطار النظرىع والدر|سانه السابقة :}

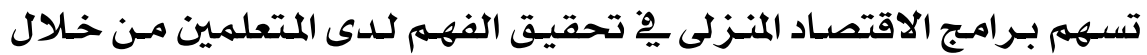

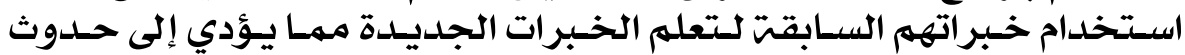

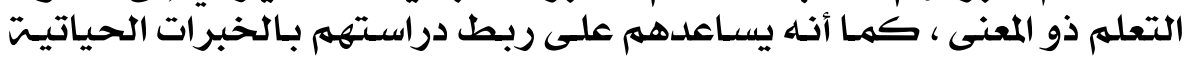

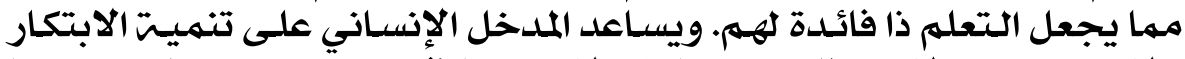

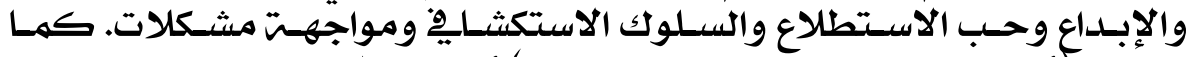

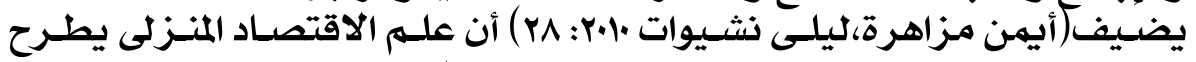

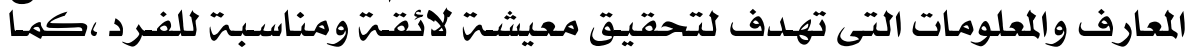

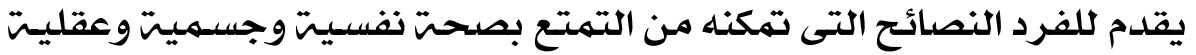

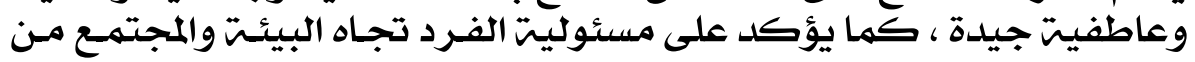

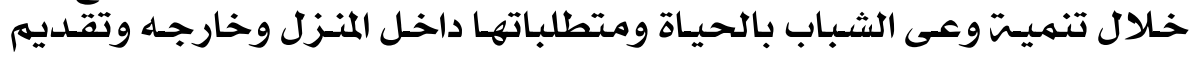

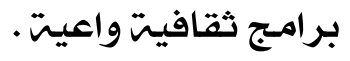

• المحور الاول : ننمية الأمن الفكرى للطالبانه/ معلمانه الإقنصاد المنزلىه :

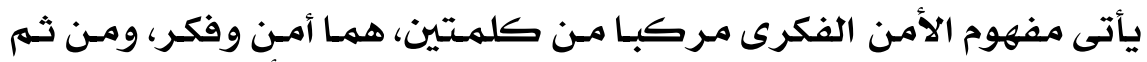

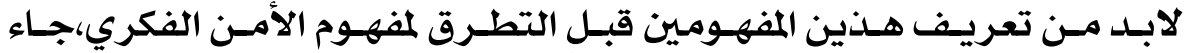


تعريف الأمـن، على أنه تأمين كيان الدولت والمجتمهمع،من الأخطار التي تهددها

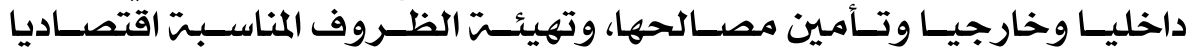

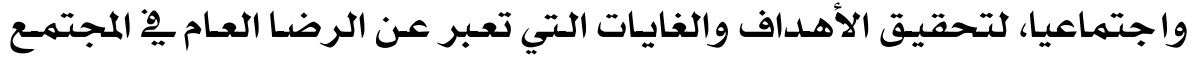

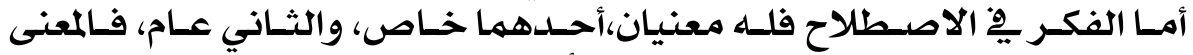

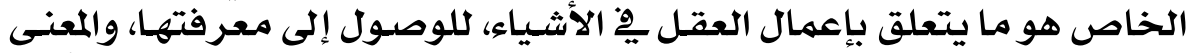

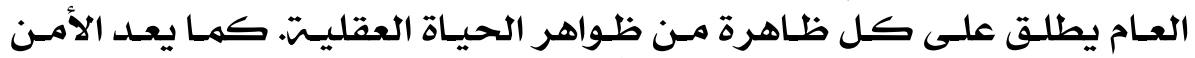

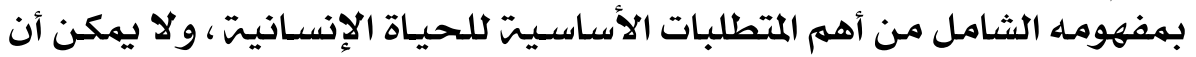

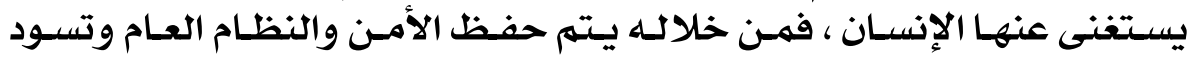

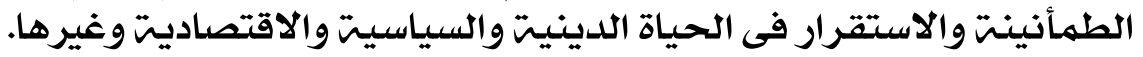

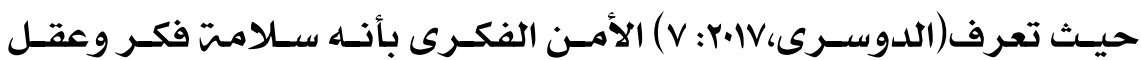

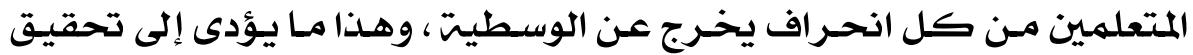

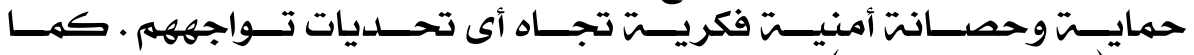

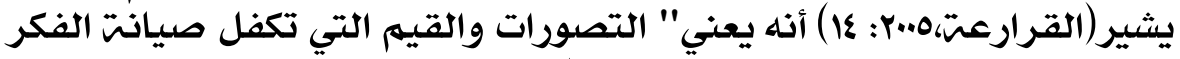

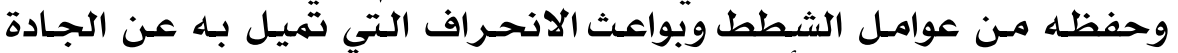

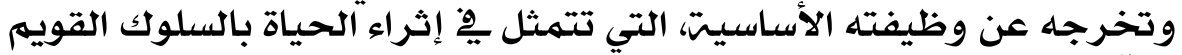

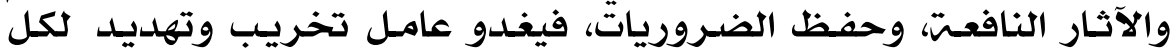

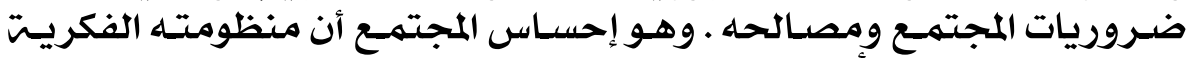

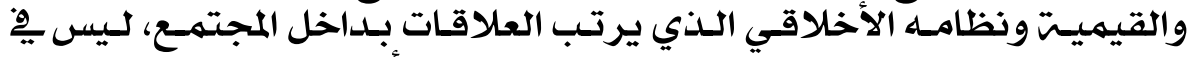

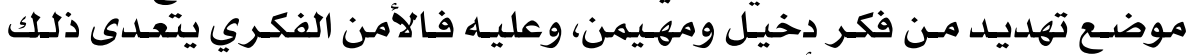

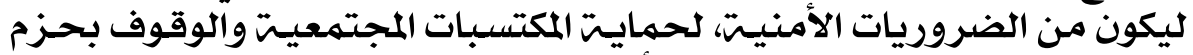

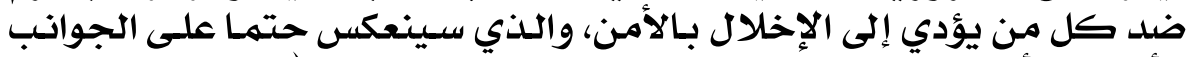

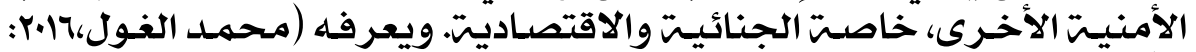

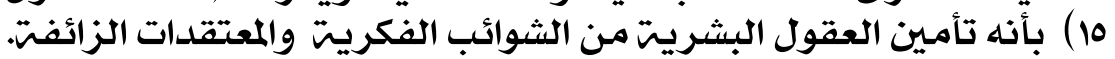

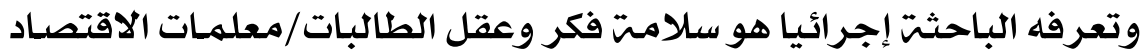

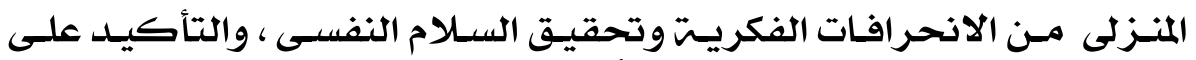

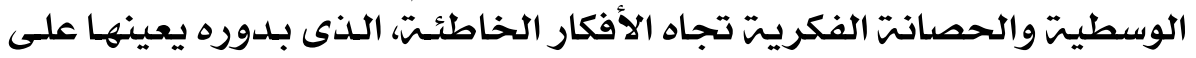

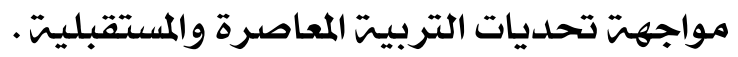

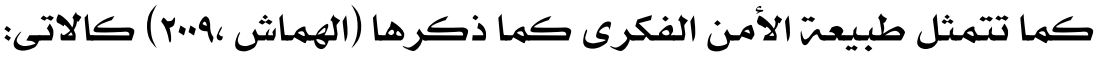

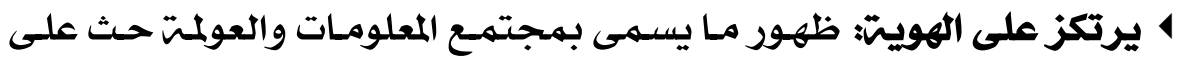

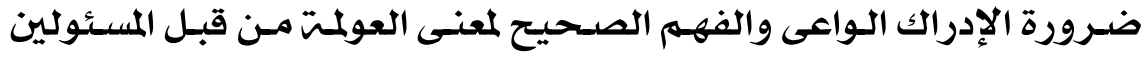

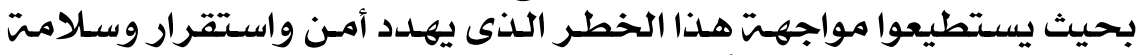

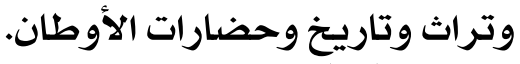

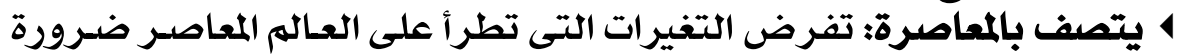

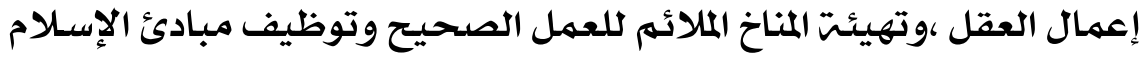

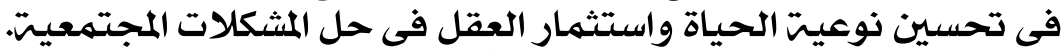
r. $\frac{1}{2} 2$ 


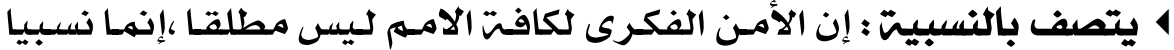

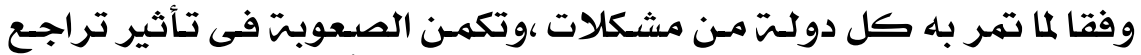

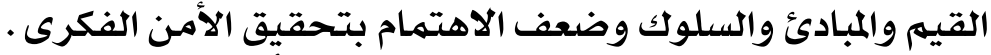

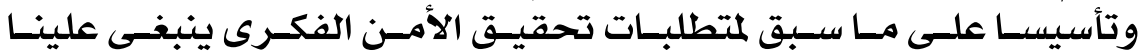

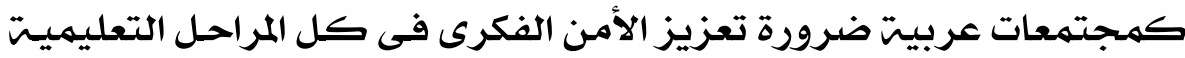

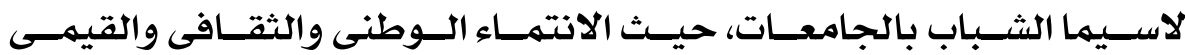

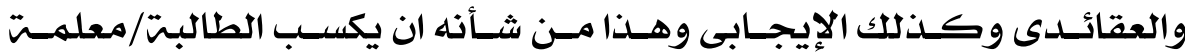

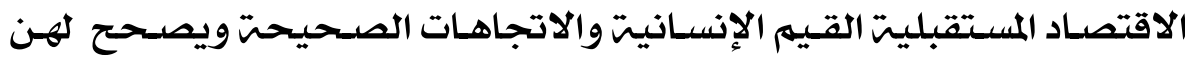

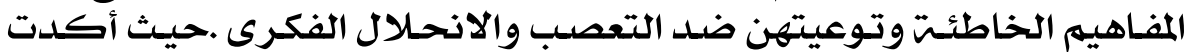

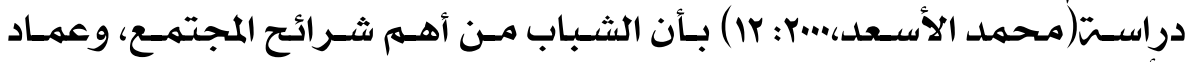

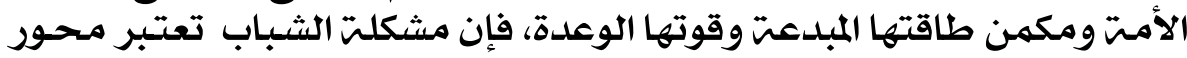

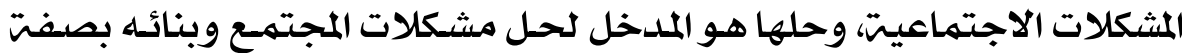

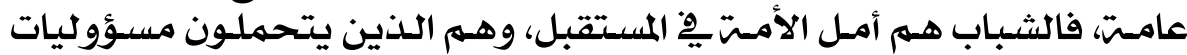

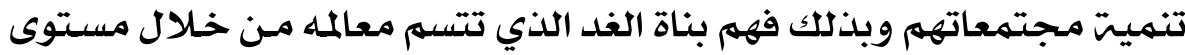

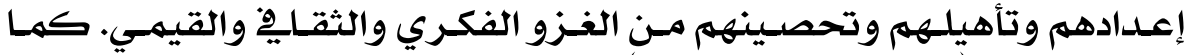

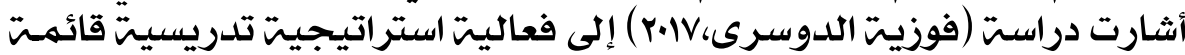

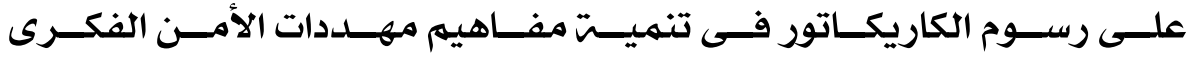

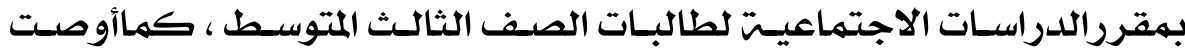

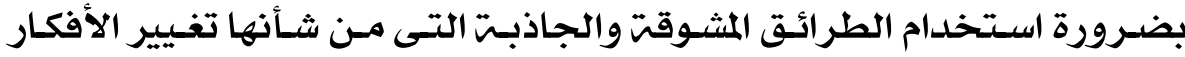
السلبيت لإيجابيتة.

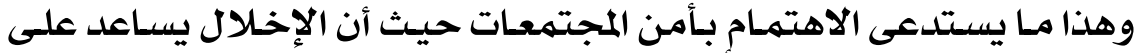

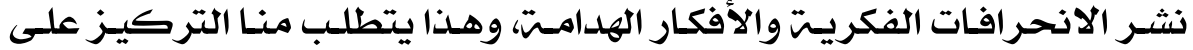

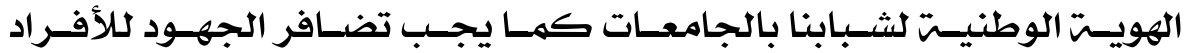

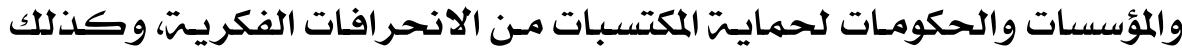

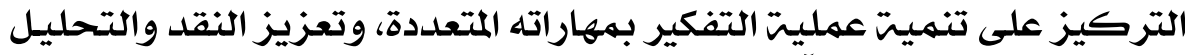

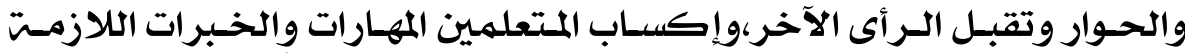

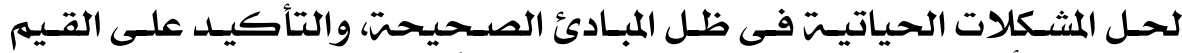

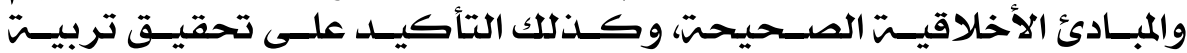

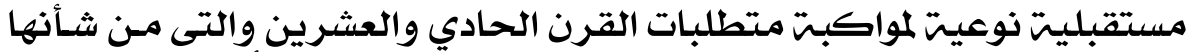

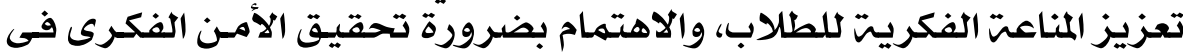

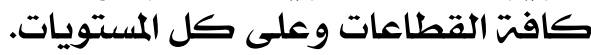
ولكى يتهم تعزيز الأمن الفكرى في عمليـت التربيـت لابــ مـن عدة متطلبـات هى كما يرى (Rubenstein,2017:265-269):

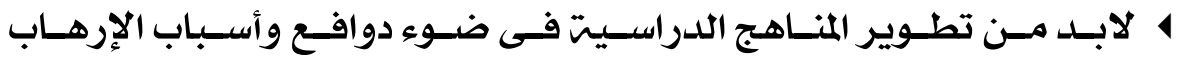
والانحراف الفكرى. 


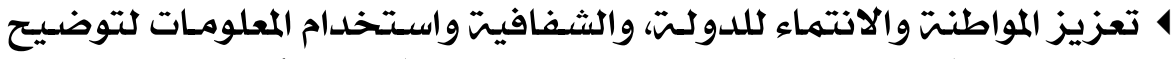

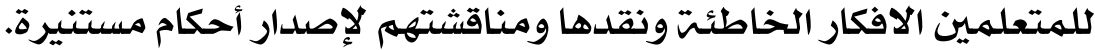

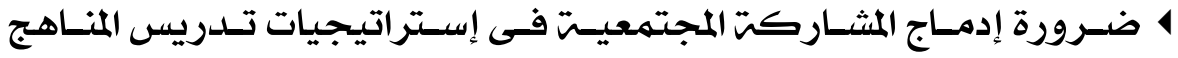

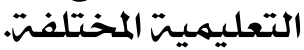

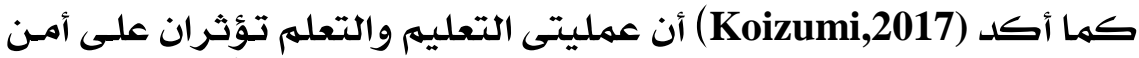

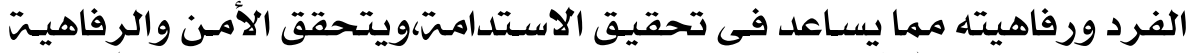

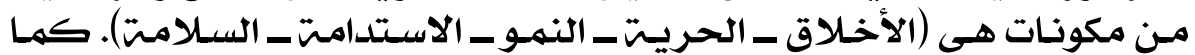

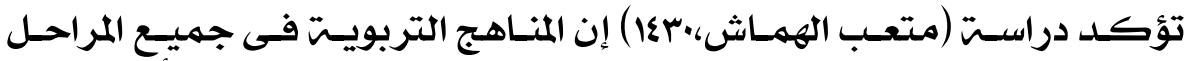

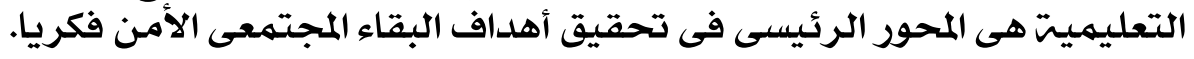

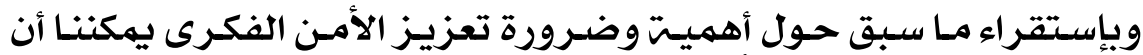

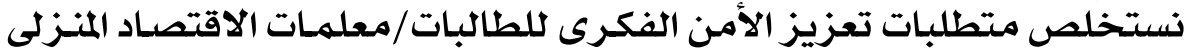
منها : نسيتح

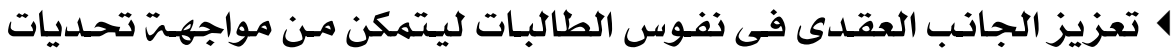

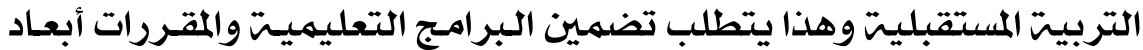

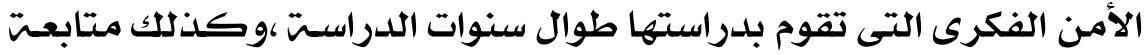

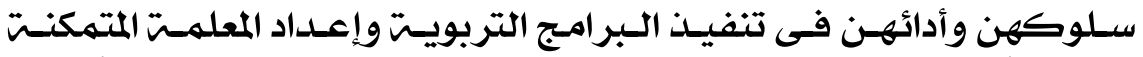

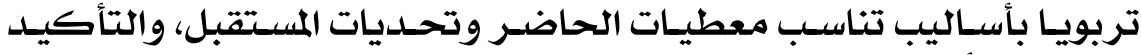

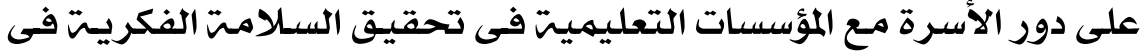

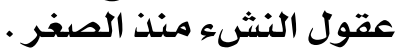

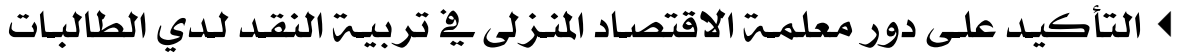

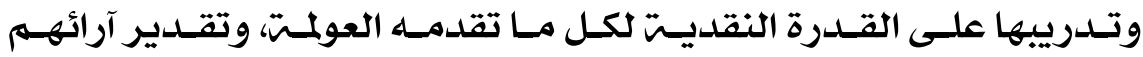

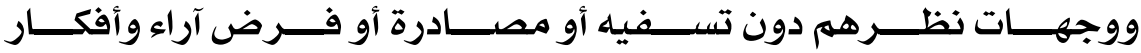

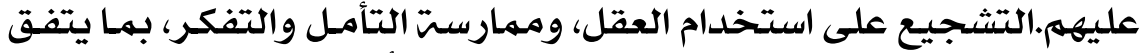

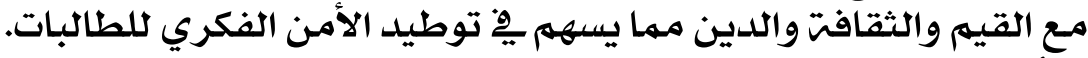

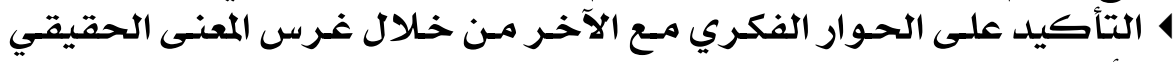

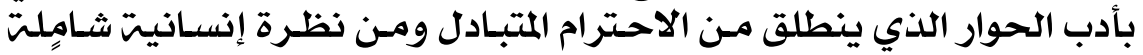

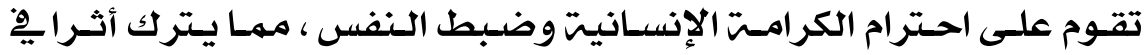

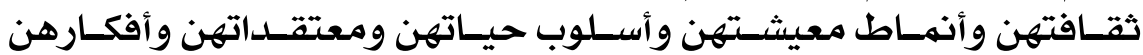

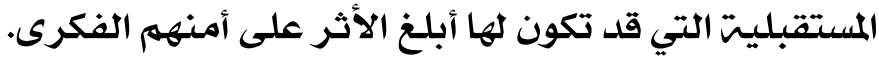

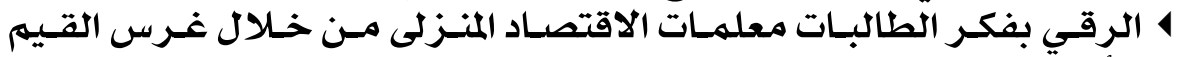

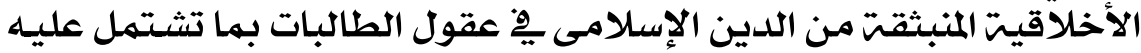

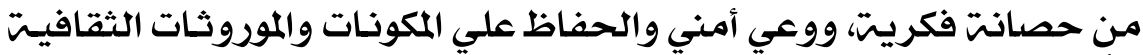

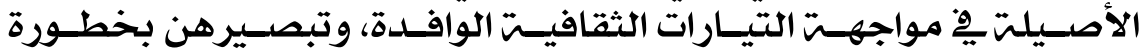

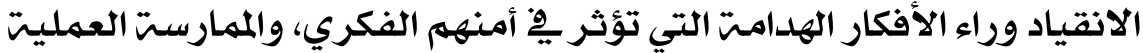

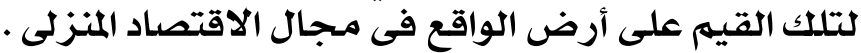
Y.V 


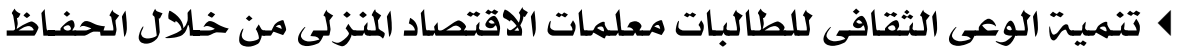

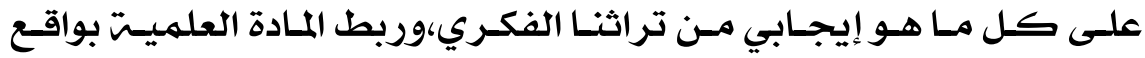

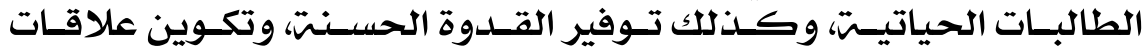

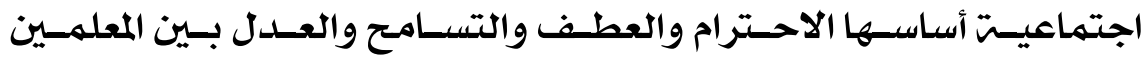
والمتعلمهين.

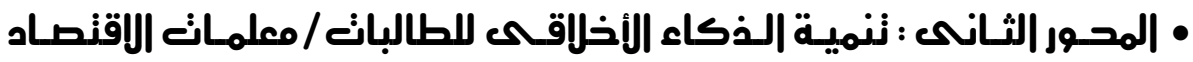

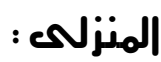

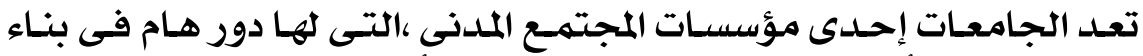

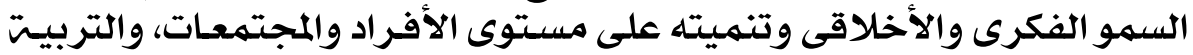

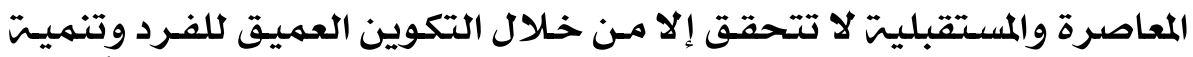

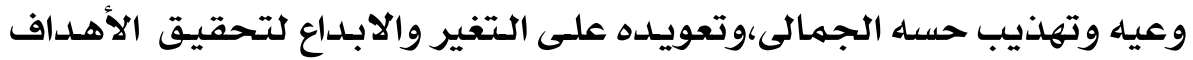

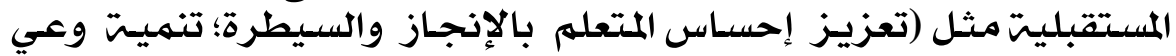

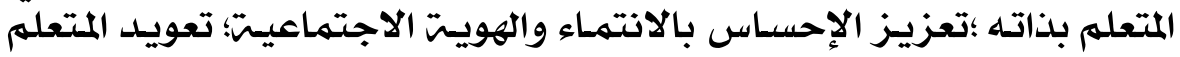

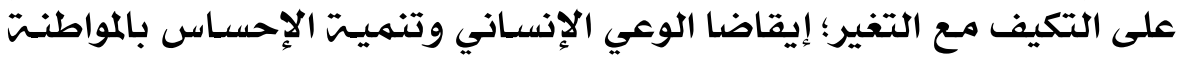
العالميتي.

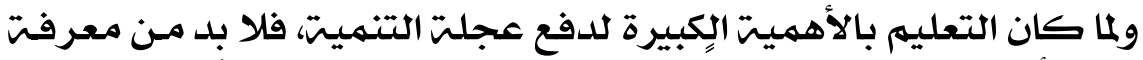

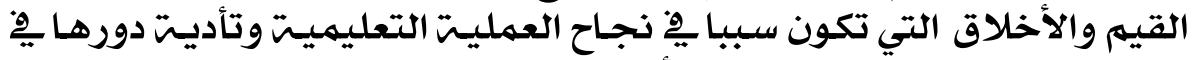

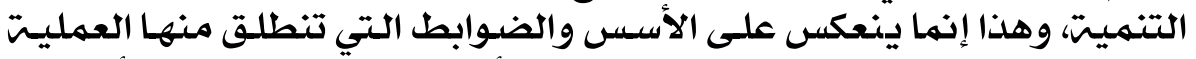

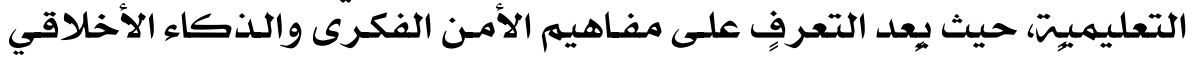

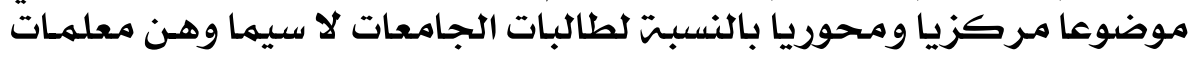

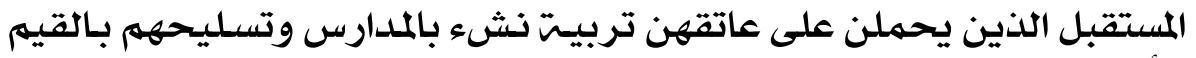

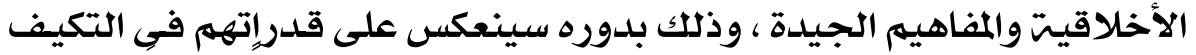

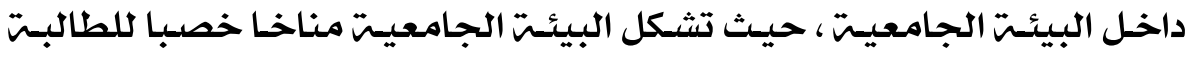

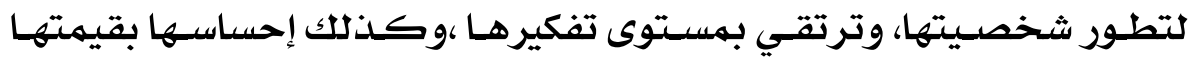

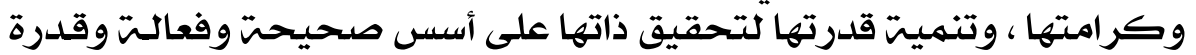

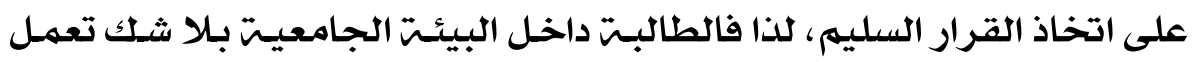

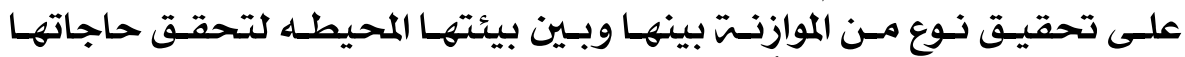

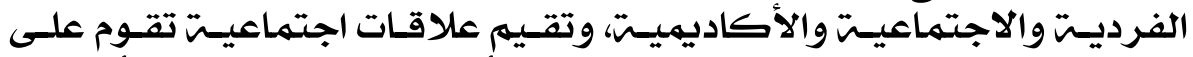

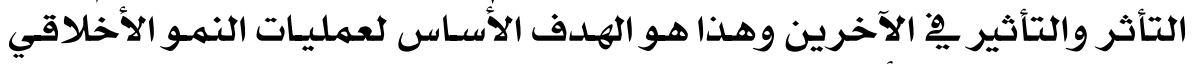

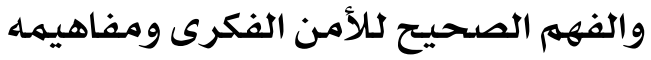

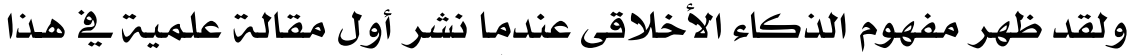

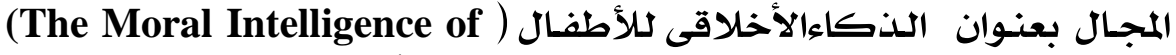

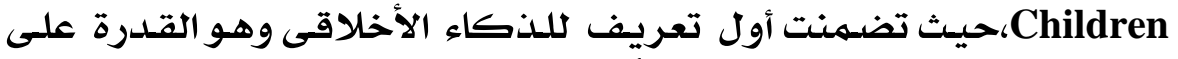

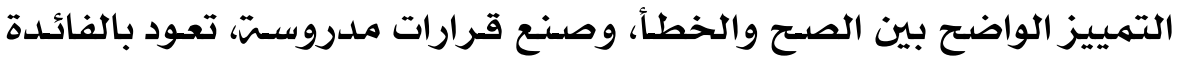

$$
r . \Lambda
$$




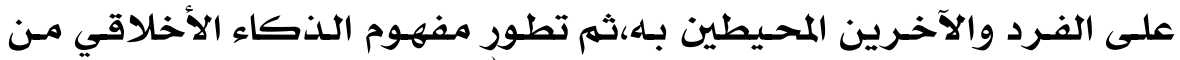

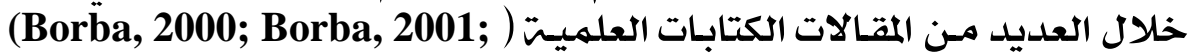

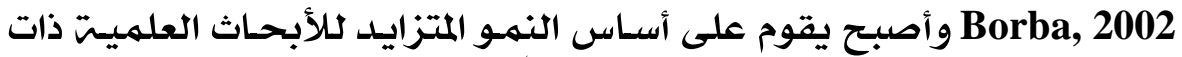

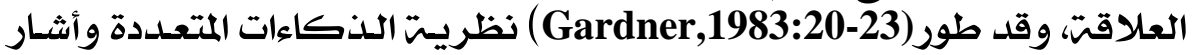

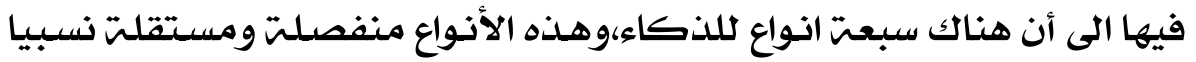

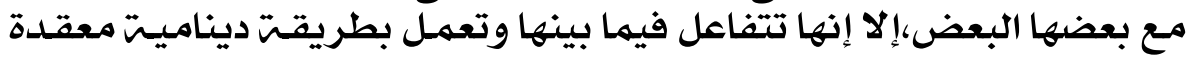

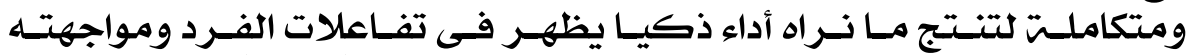

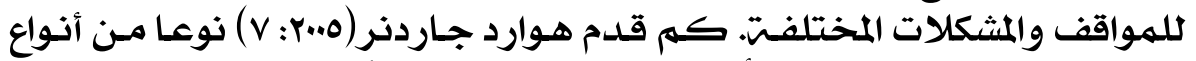

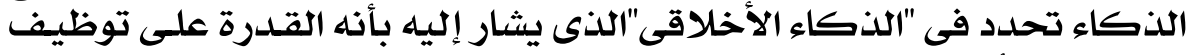

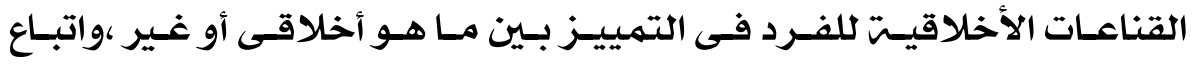

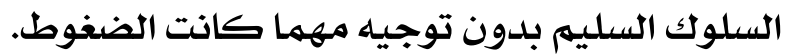

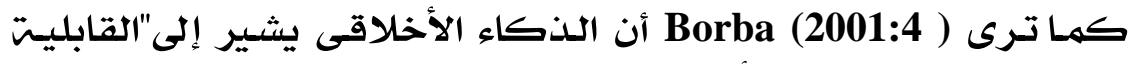

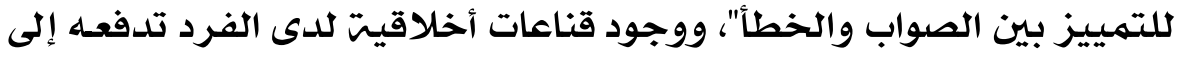

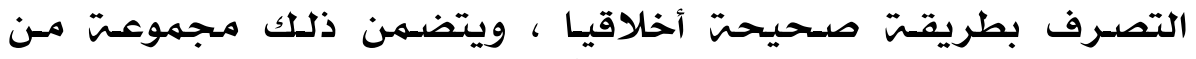

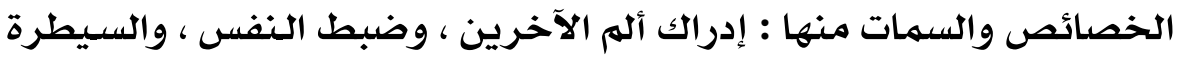

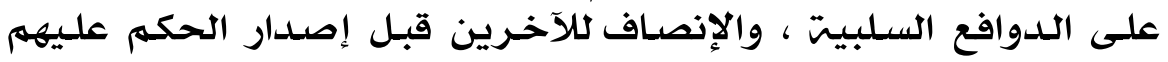

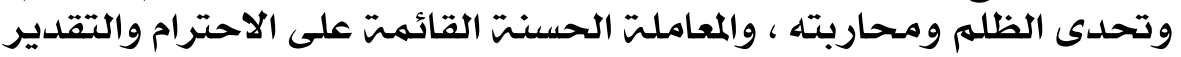
كلآخرين.

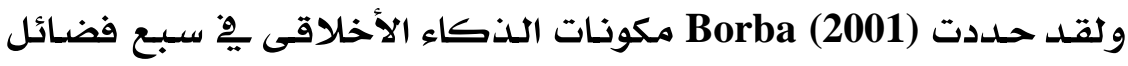
أومكونات هي:

4 التعاطف Empathy : وهو تعاطف الفرد مـع مشاعر ومخخاوف الآخرين

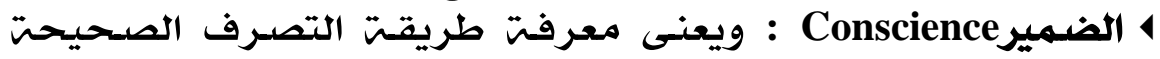
واللائقت والعمل بهذه الطريقتة.

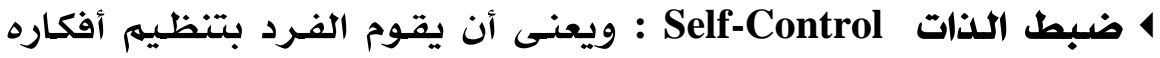

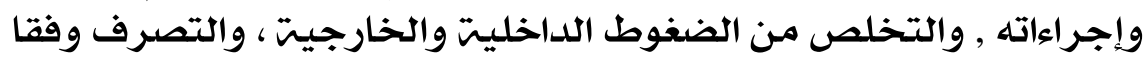

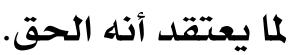

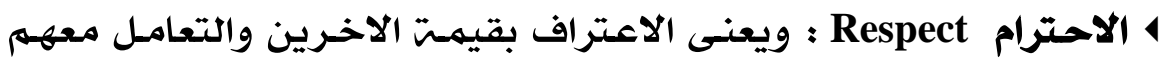
بطريقت مهذبت وحلهم.

4 العطف Kindness :ويعنى إظهار القلق إزاء ما يشعر بـه الآخرون.

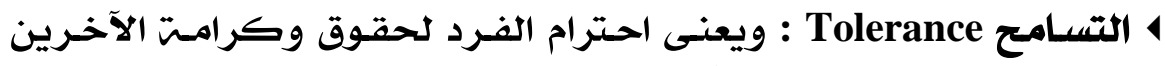

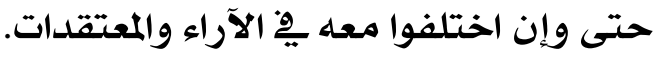

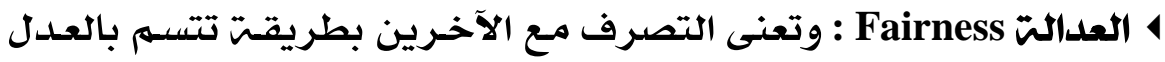
والإنصاف ، والانفتاح عليهم. 
• أسس ننمية الفكاء الأخلاقه:

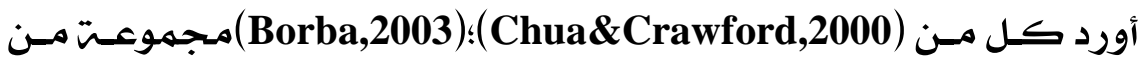
الأسس والمبادئ لمساعدة معلم المستقبل لتنميت الذكاء الأخلاقى للمتعلمين

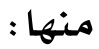

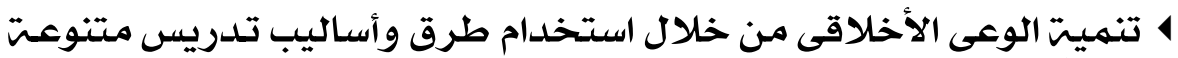

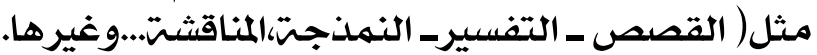

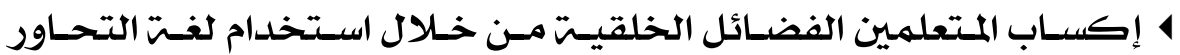

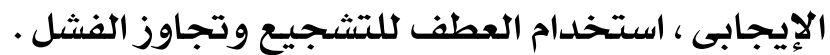

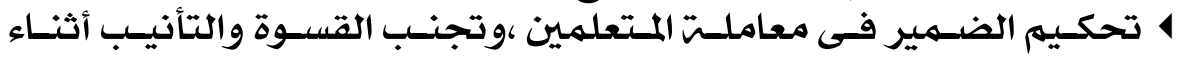
الاسئلت.

4 تدريب المتعلمين على اتخاذ القرارات الأخلاقيت وتحمل المسئوليتية.

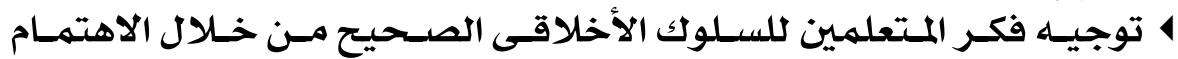

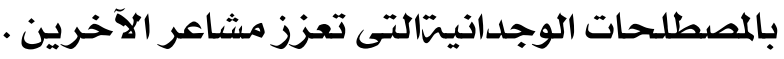

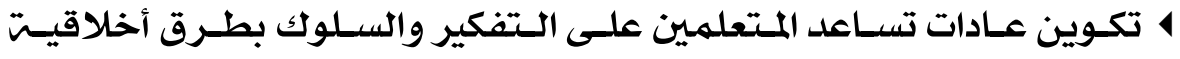
مناسبت. 4 كتحرى الأمانت في التعاملات المختلفت. 4 استخدام أساليب مختلفتّ في مضمونها الاحترام والتقدير لاثارة الدافعيت

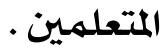

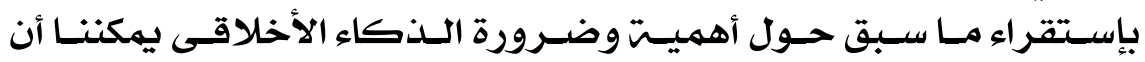

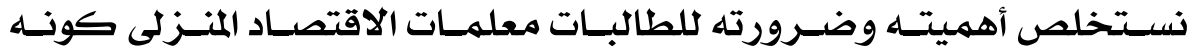

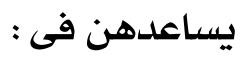
4 التحلى بالصبر والتأنى عند مواجهت مشكلات المتعلمين واتخاذ قرار صائب بشأنها. ل تدريس القضايا الحياتيتة بطرق تبرز أهميتة الفكر الصحيح نحو الأفكار

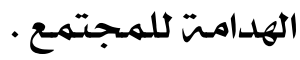

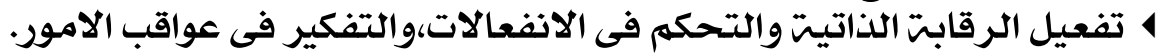

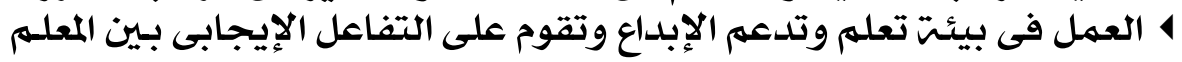

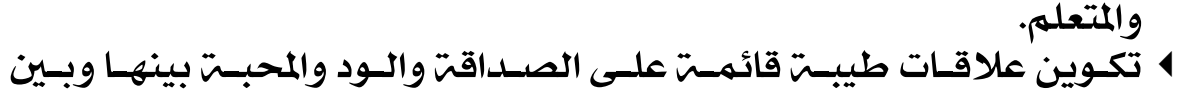

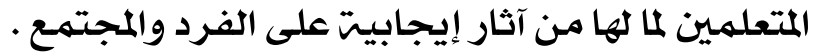

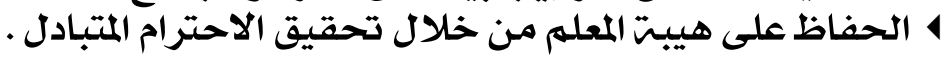

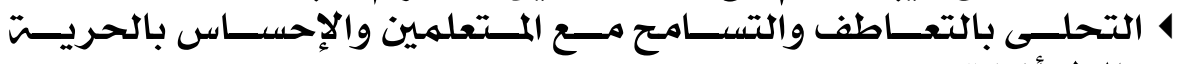
والطمأنينت.

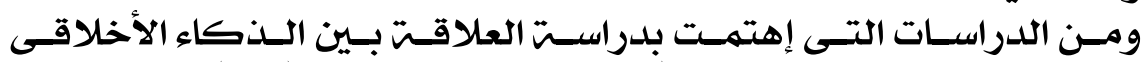

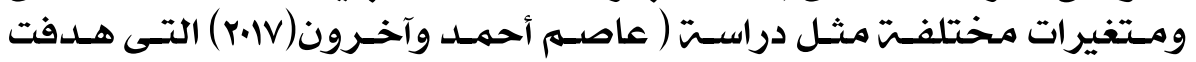
rl. cres 


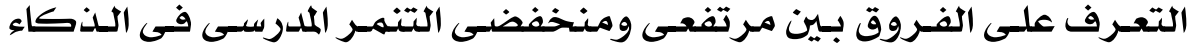

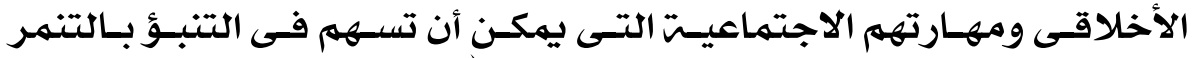

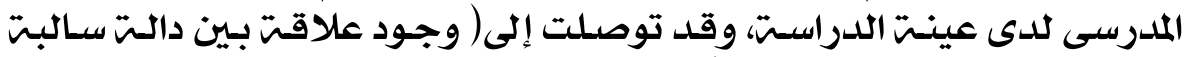

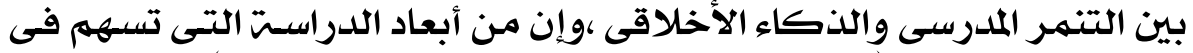

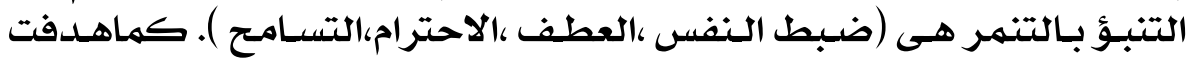

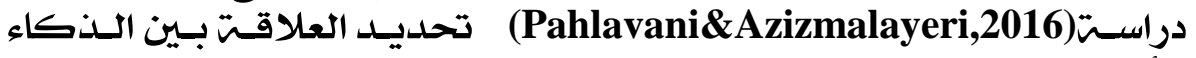

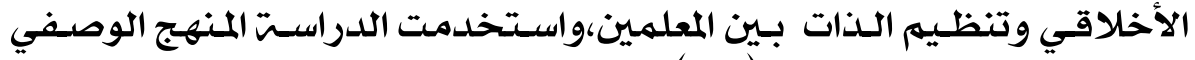

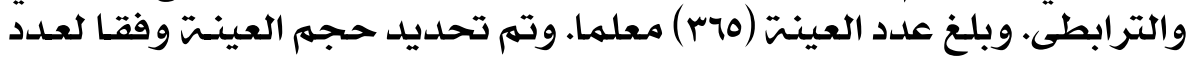

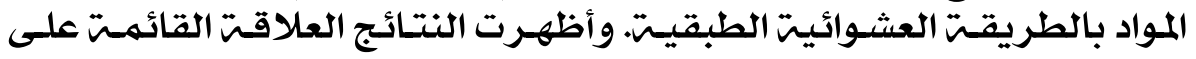

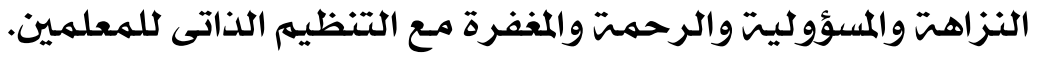

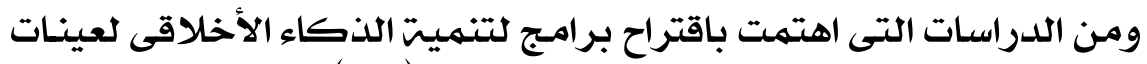

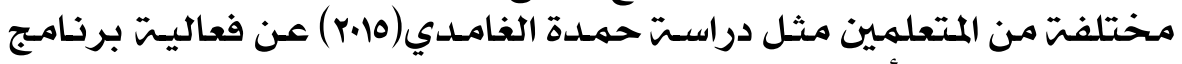

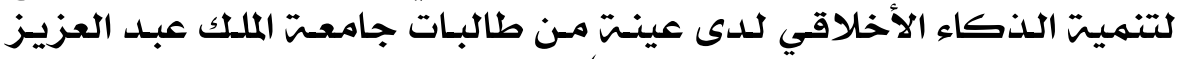

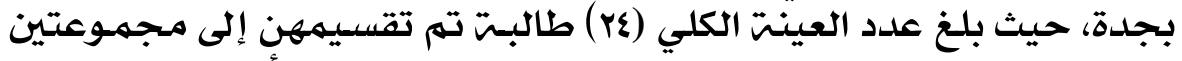

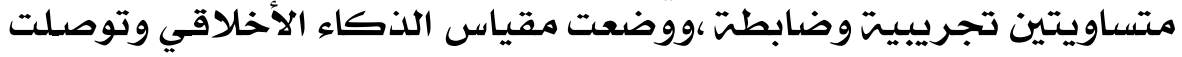

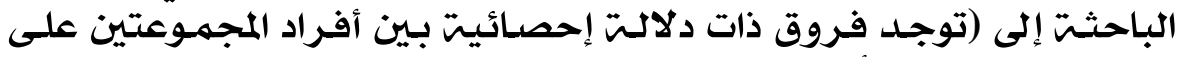

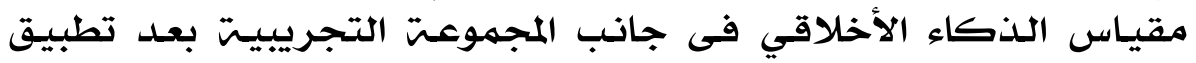

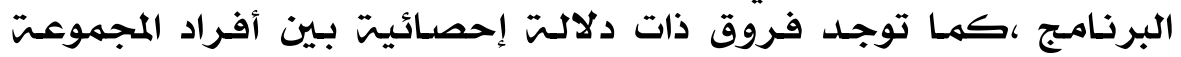

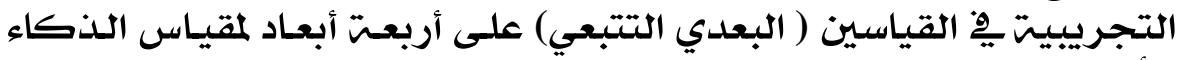

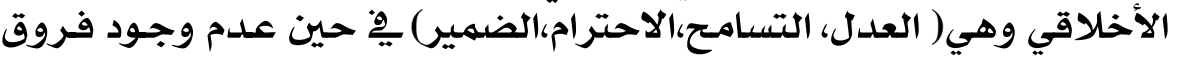

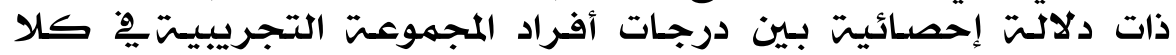

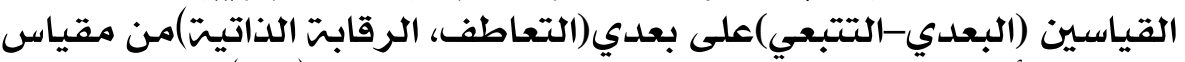

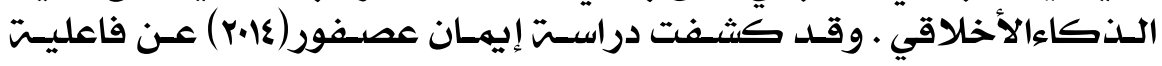

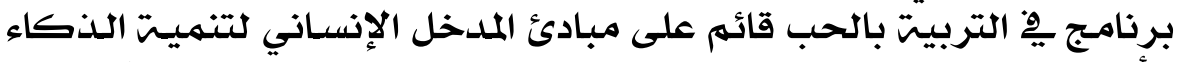

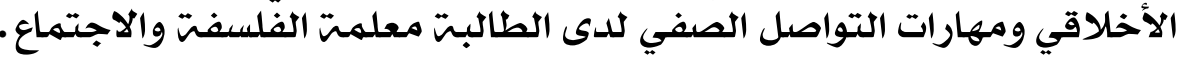

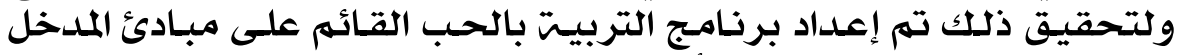

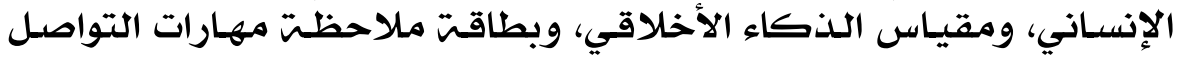

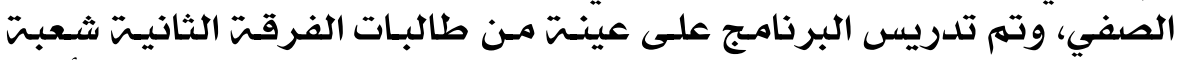

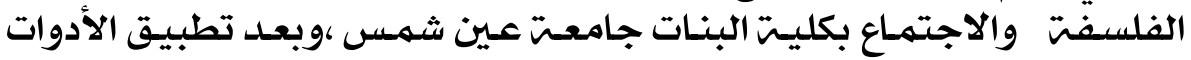

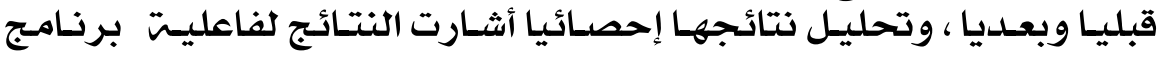

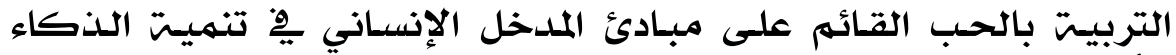

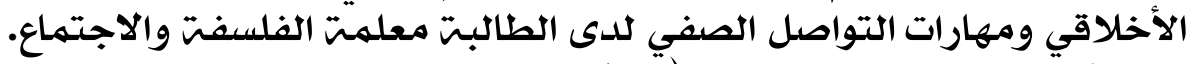

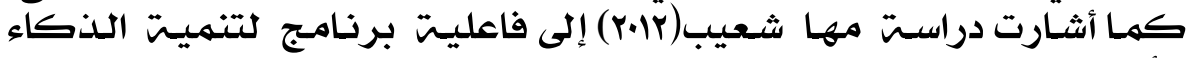

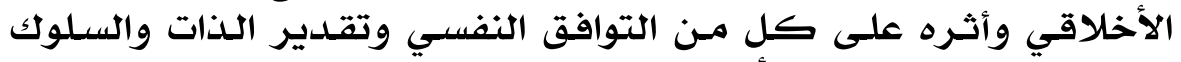

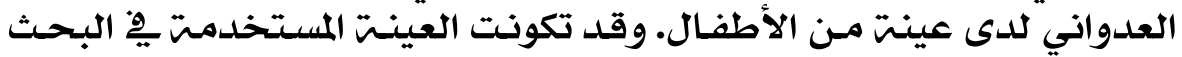




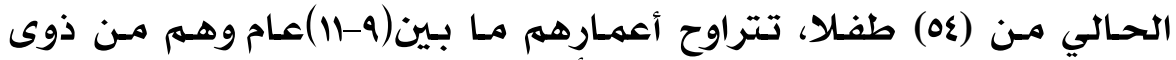

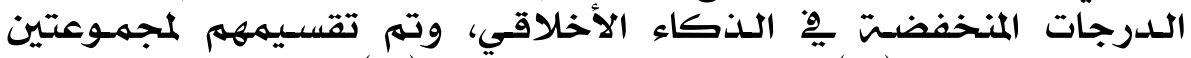

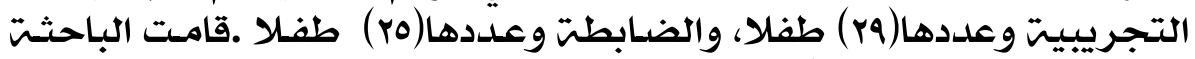

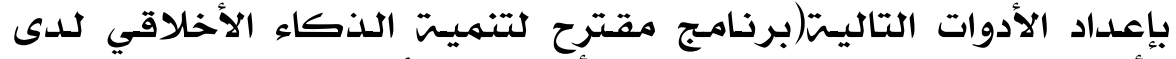

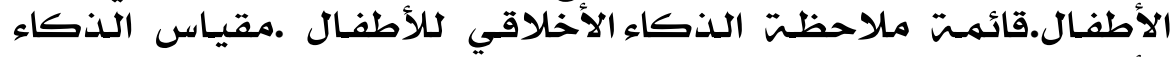

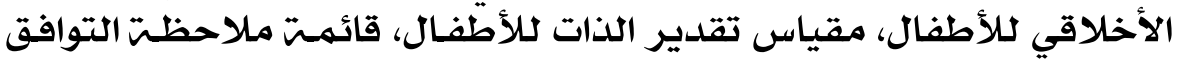

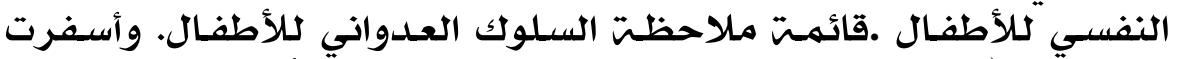

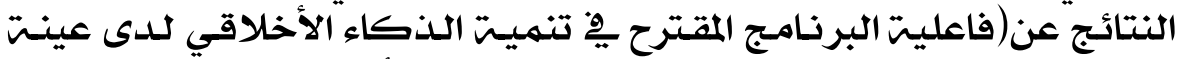

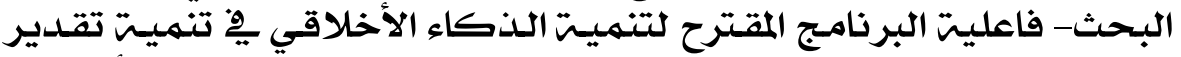

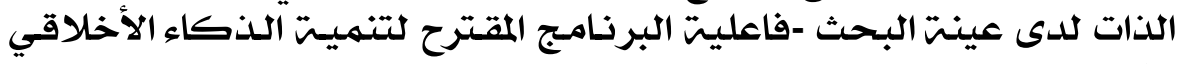

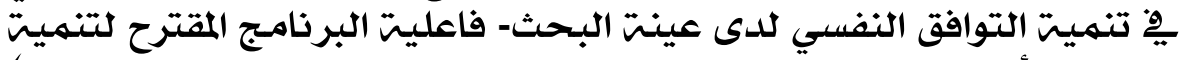

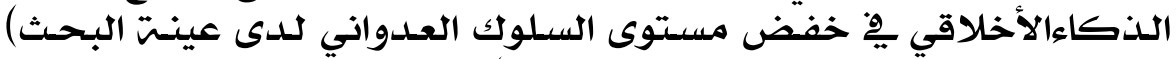

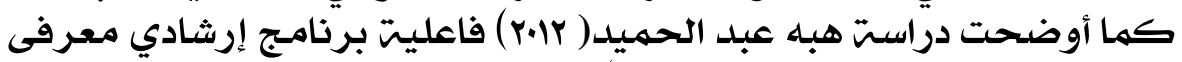

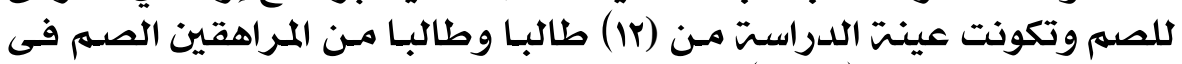

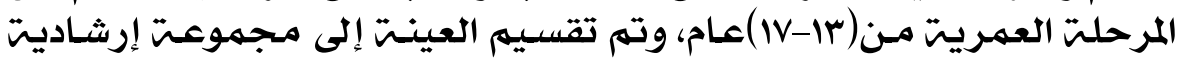
ومجموعت ضابطت.

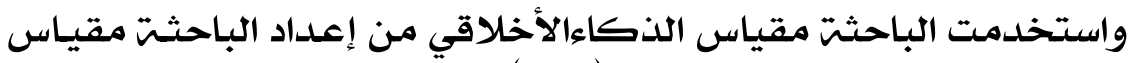

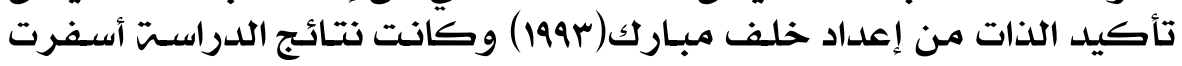

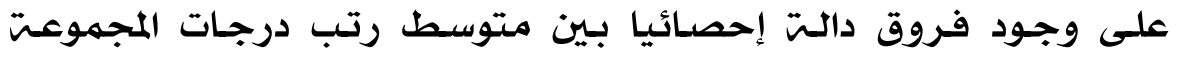

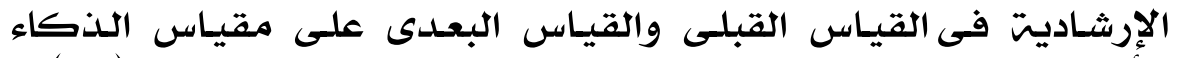

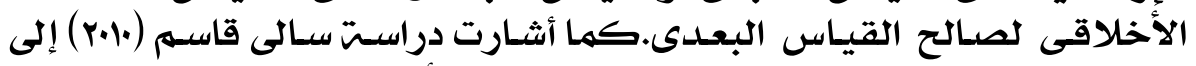

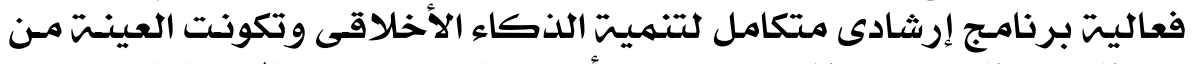

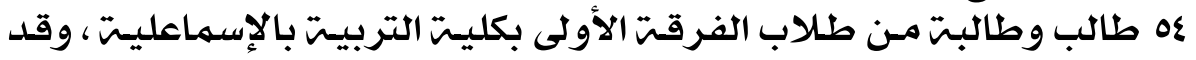

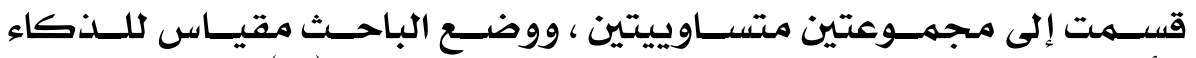

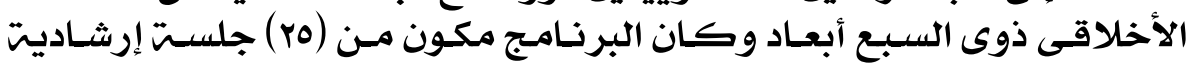

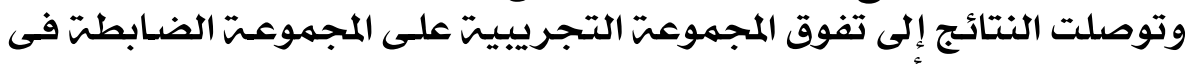

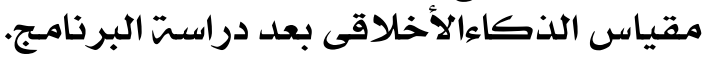
• المحـور الثالـث : نــــيانه التربيـة المسـنْبلية وأدوار الطالبانه / معلمـانه الإقنصاد المنزله لمهو|جهنها:

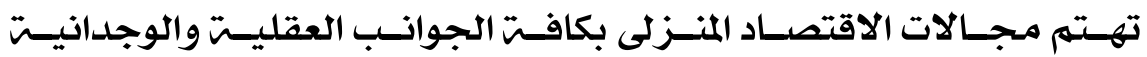

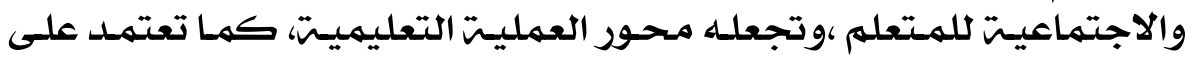

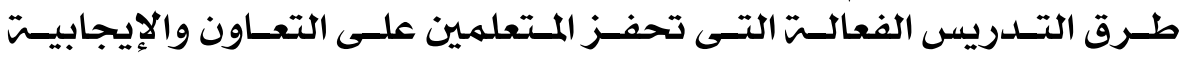

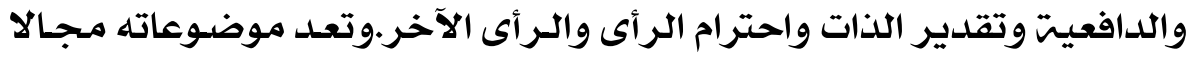

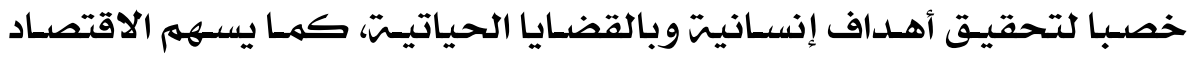




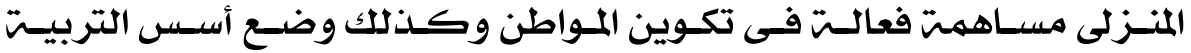

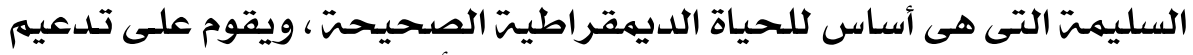

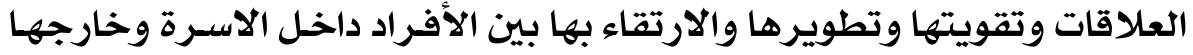

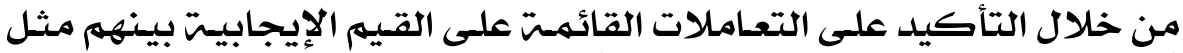

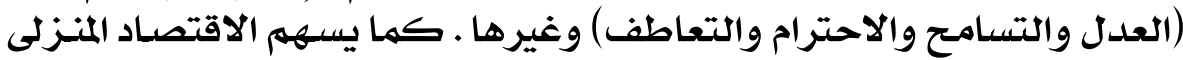

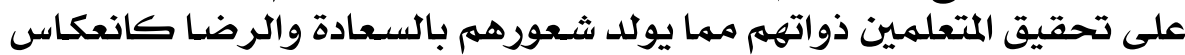
لتحقيق قدراتهم. تصحيق

\section{• نحديد|نَ|التربية المسنقبلية:}

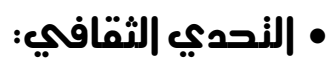

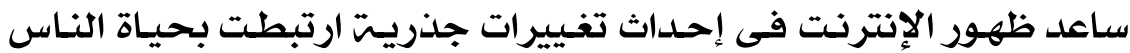

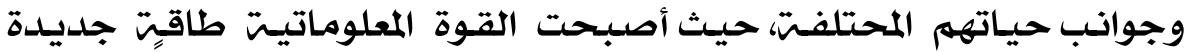

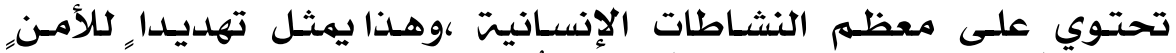

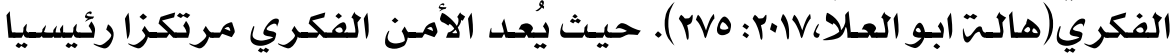

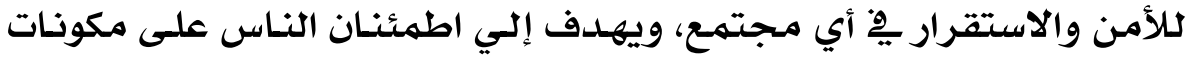

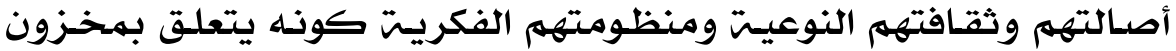

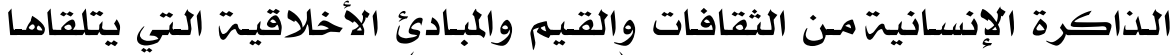

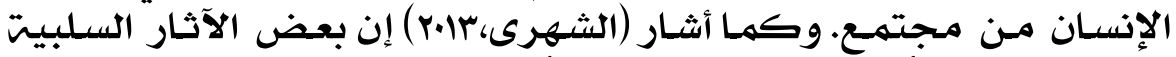

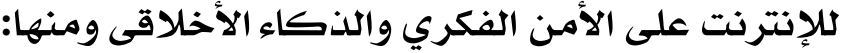

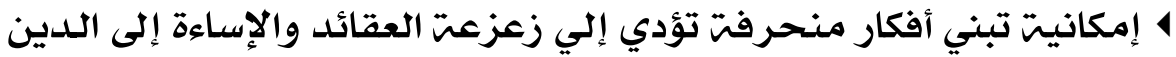

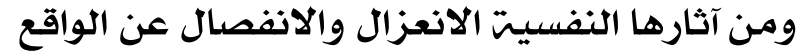

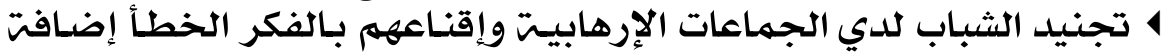

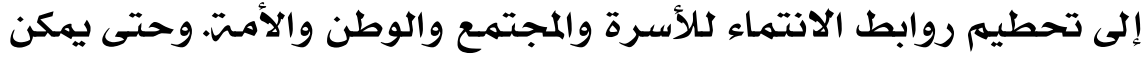

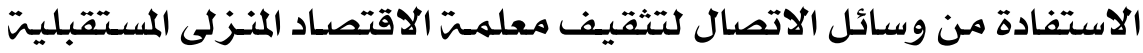

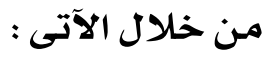

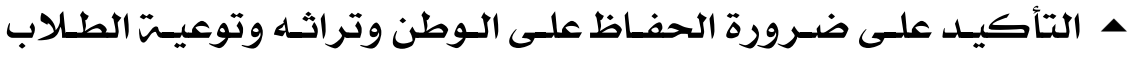
بالمخاطر السلبيت للعولمتئ.

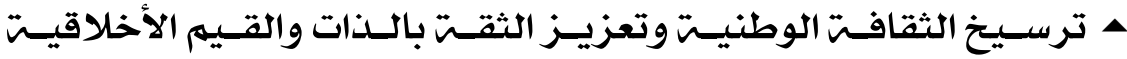

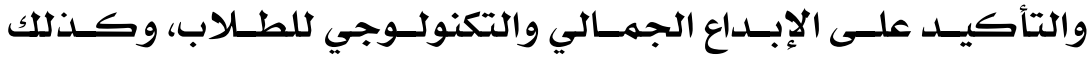

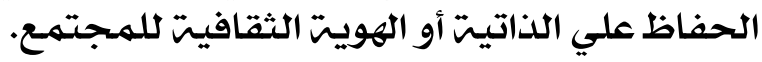

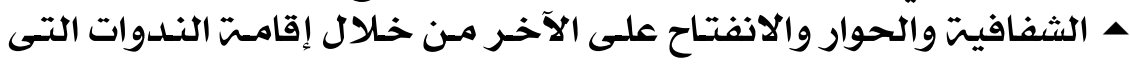

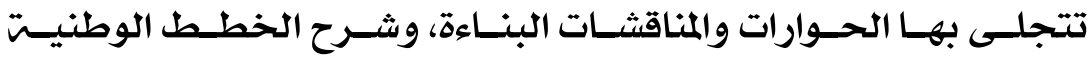

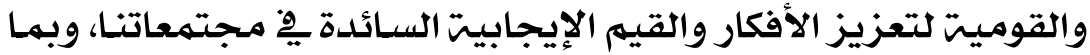

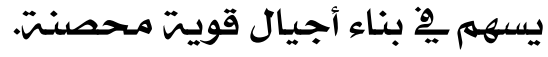




\section{(أبريل .. 1 ا • آمي}

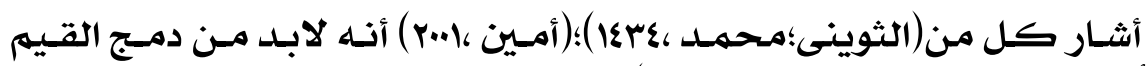

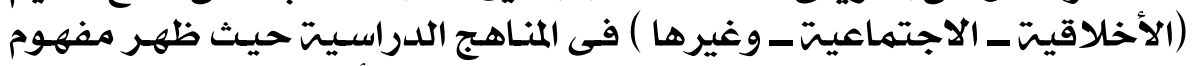

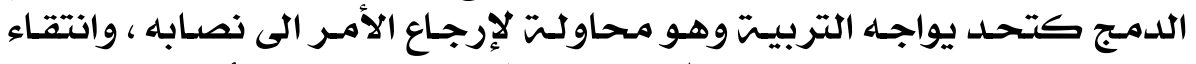

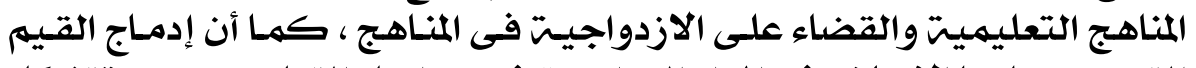

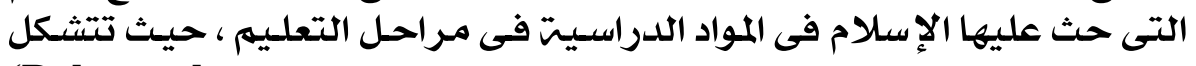

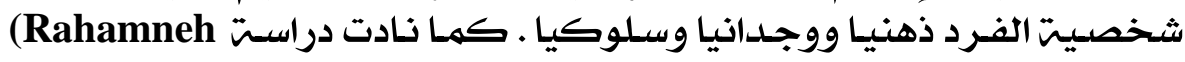

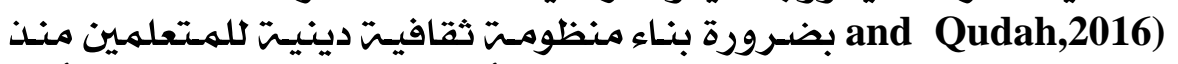

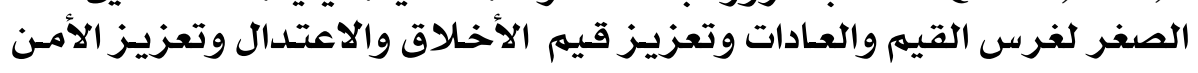
الفكرى.

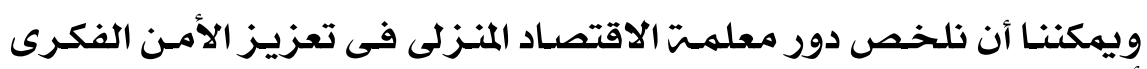

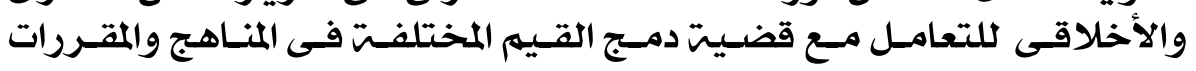

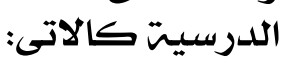

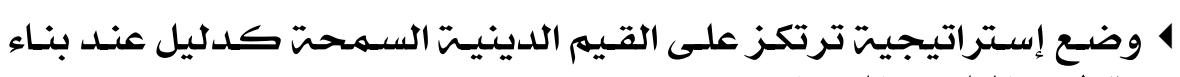

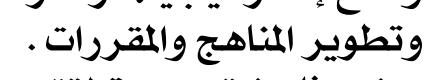

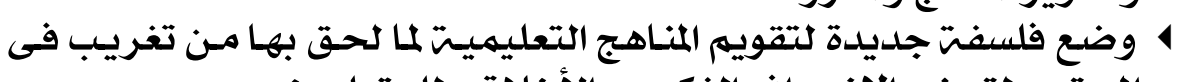

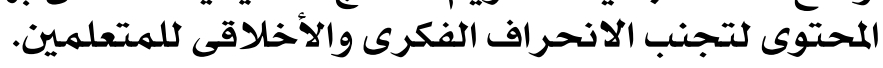

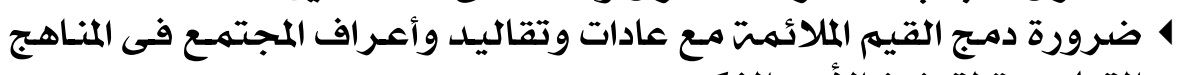

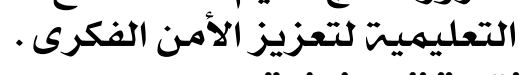
• التربية المسندم|مه: الميزيز

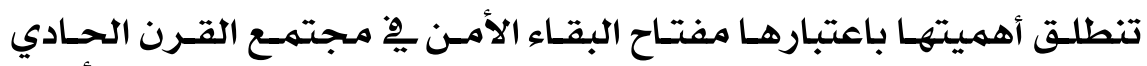

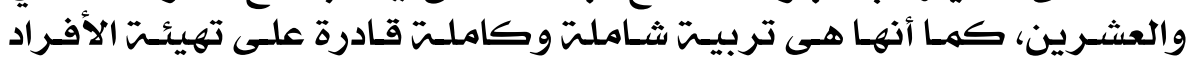

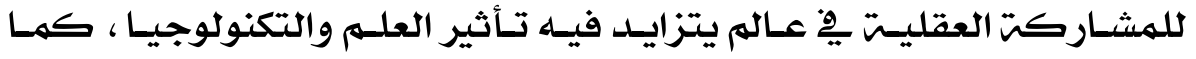

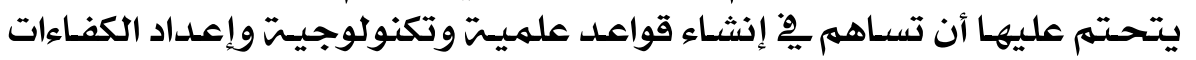

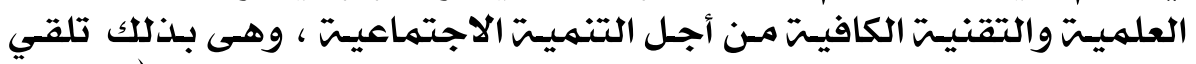

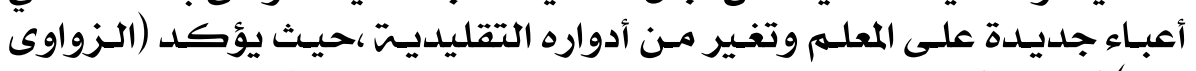

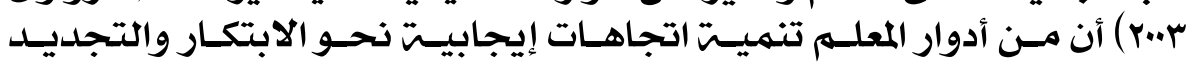

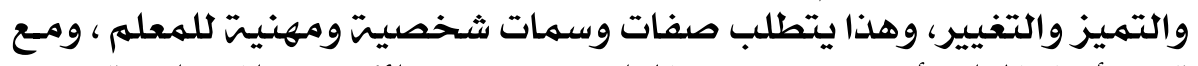

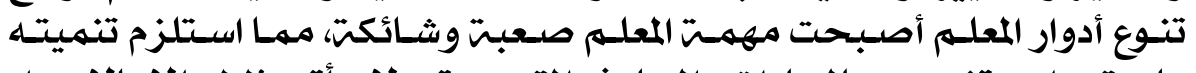

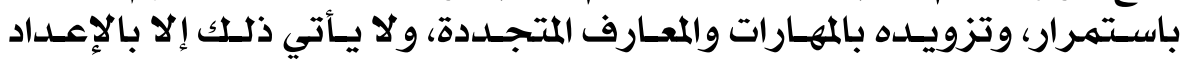

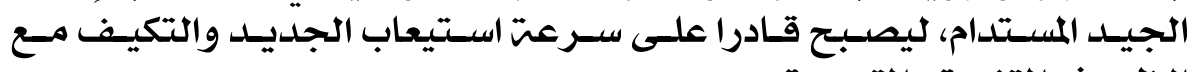

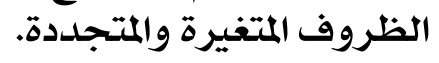

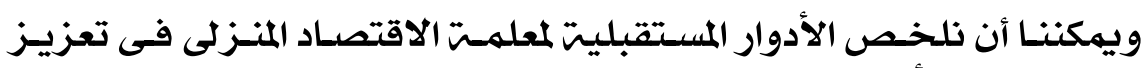

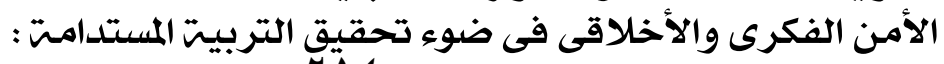
ع أ $\frac{1}{2}$ 


\section{(أبريل .. 1 - •أمي}

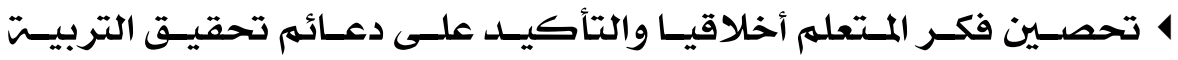
المستدامتة.

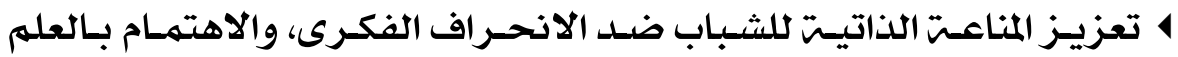

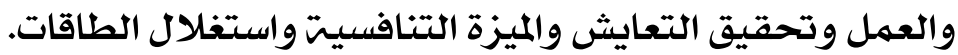
4 كذلك فتح آفاق للحوار المجتمعى يعزز الهويت المنافيت الفكريت الحضاريت ويحفز على استدامتها.

• ق قيادة |لنفيير:

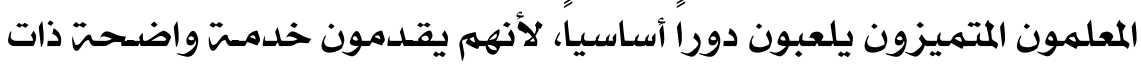

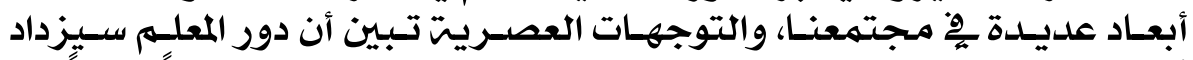

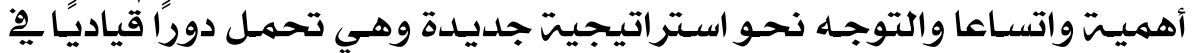

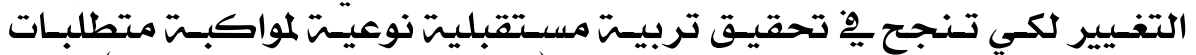

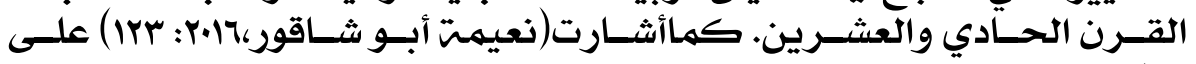

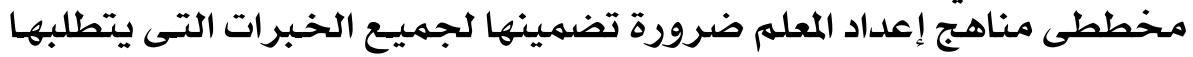

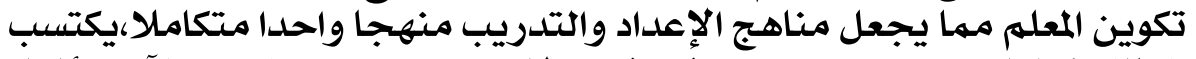

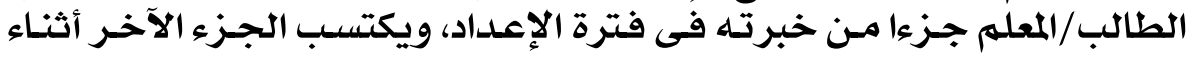

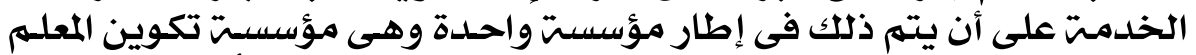

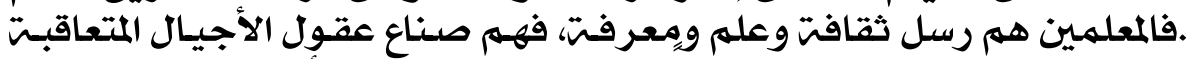

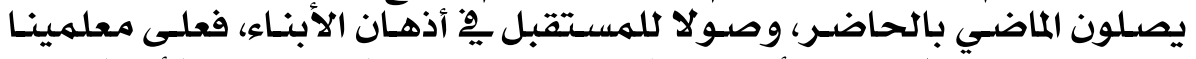

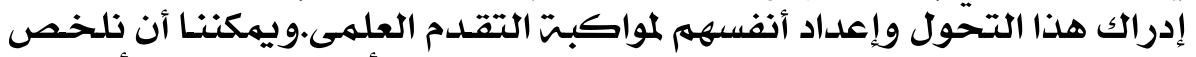

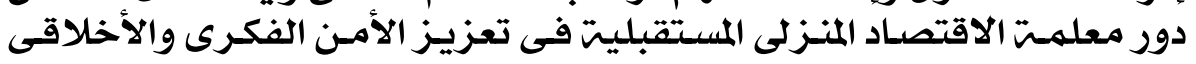
باعتبارها قائدة التغيير فيما يلى :

4 قيـادة التغـيير مــع الحفـاظ على كلى كل مـا هـو إيجـابي وأخلاقى مـن تراثنـا

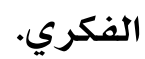
4 اليقظتّ الثديدة عند وضع وتطوير المناهج وإختيار المقررات بحيث تحقق التناغم والانسجام بين القيه وعولمتئ القيه.

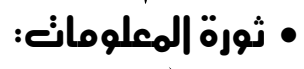

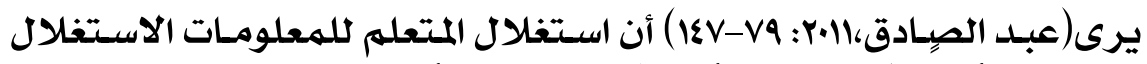

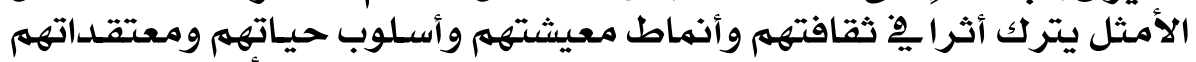

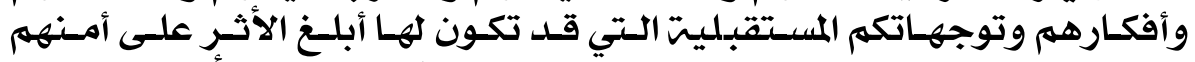

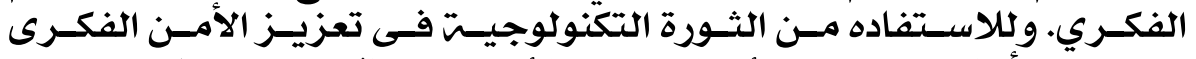

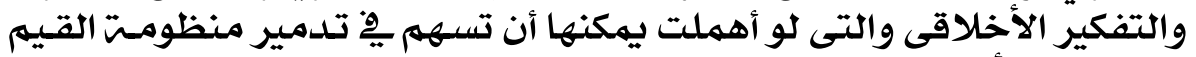
التربويت والأخلاقيت عند شرائح الطناب.

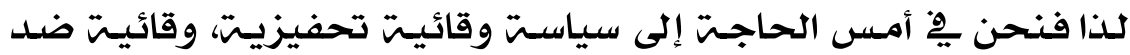

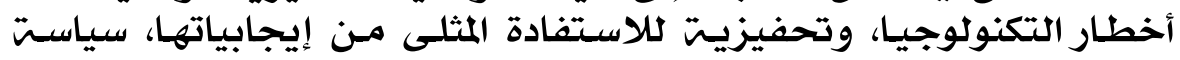

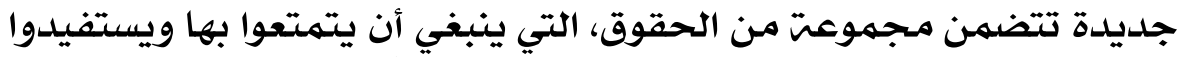

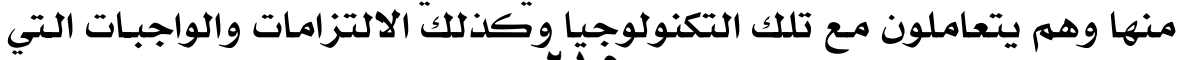
rijo $\stackrel{4}{2} 2$ 


\section{(أبريل .. 1 - •آم}

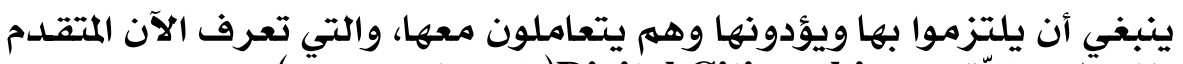

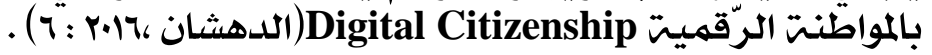

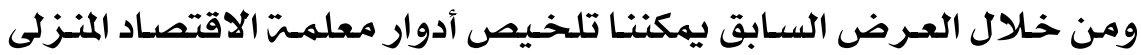

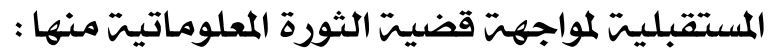

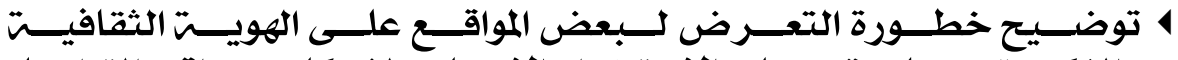

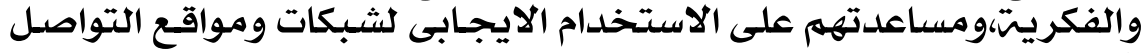

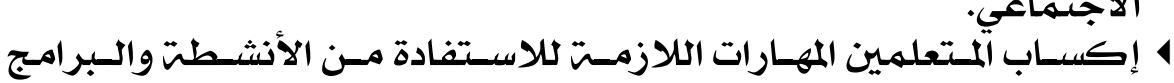

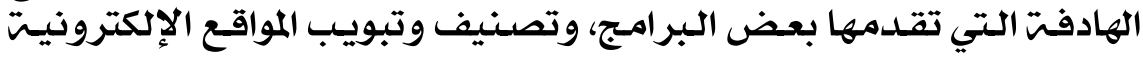
الهادفت.

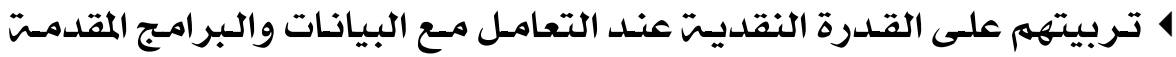

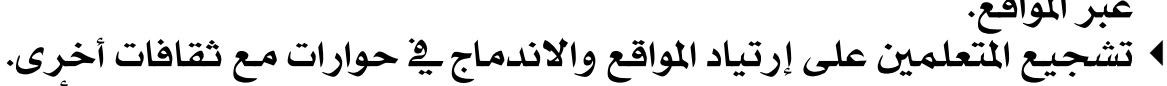

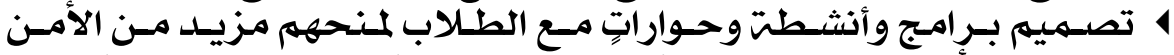

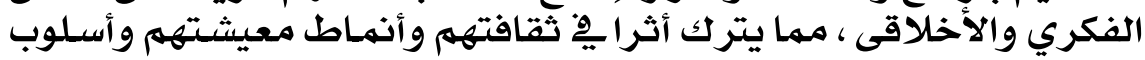

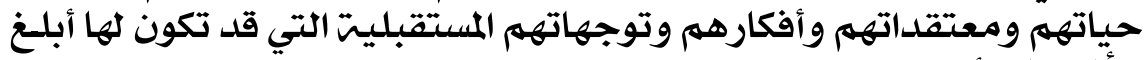
الأثر على أمنهم الفكرئه

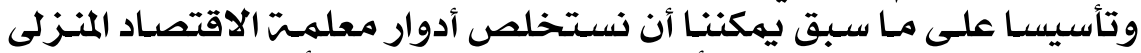

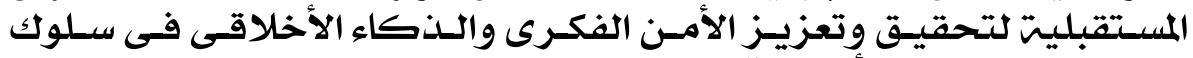

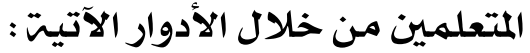
4

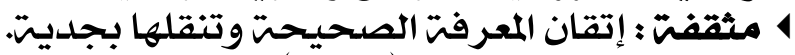

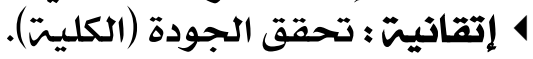

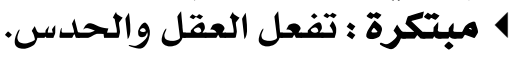

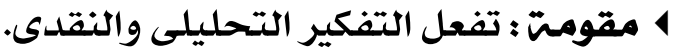

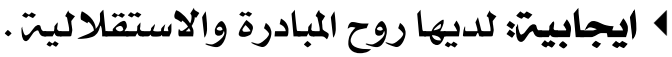

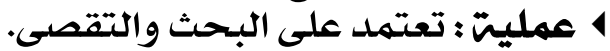

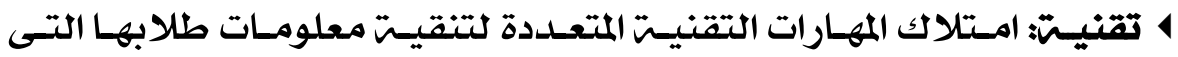

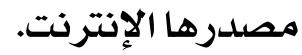

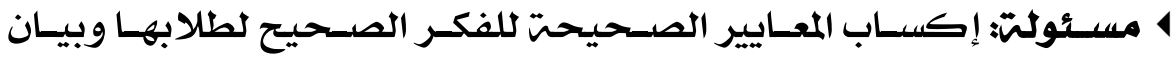
أهميتها. 4 مستقلتة : التمتع بروح الاستقلاليت وتشجيع طلابها على الاستقلاليت فى اتخاذ القرار.

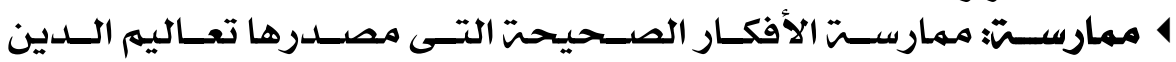

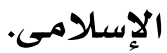
4 اجتماعيتّ : الاهتمام بالعمل بالمجموعات والفرق . Y 
4 مشاركت وللديها اختيار: تشارك في تنويع أساليب وطرق التعليه .

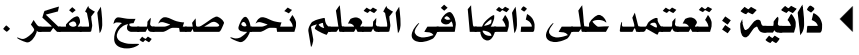

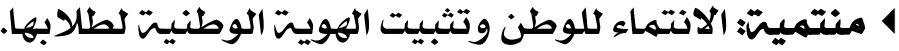

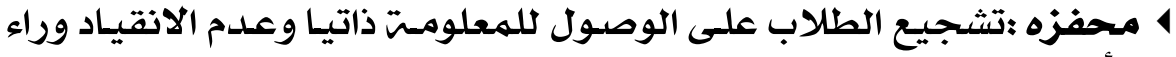
الأفكار الخاطئتة

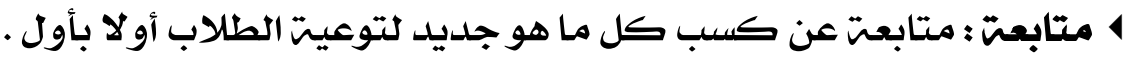

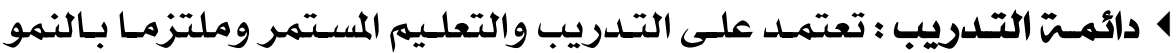

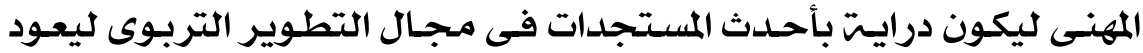

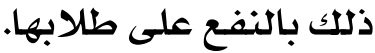

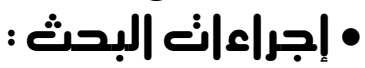
تسير الإجراءات الميدانيت وفق مجموعت من الخطوات التاليت :

4 أولا: بناء البرنامهج التدريبى المقترح ·

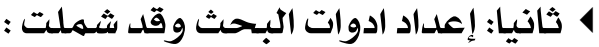

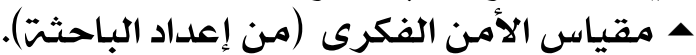

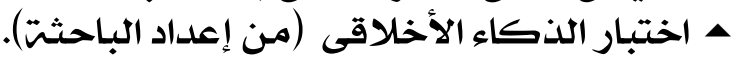

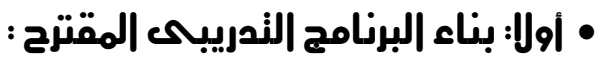

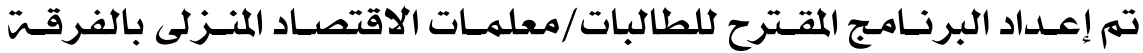

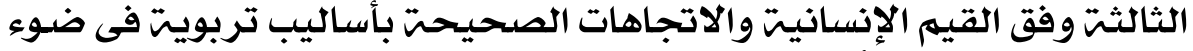

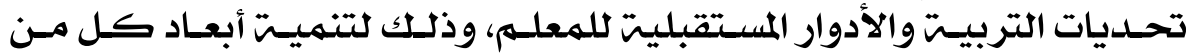

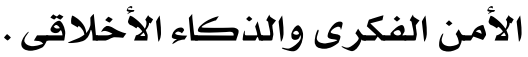

• نحديم أهد|فَ البرنامج :

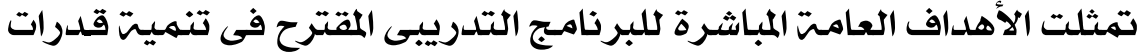

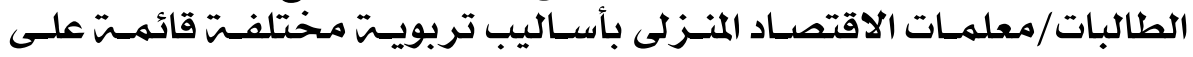

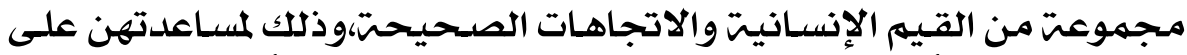

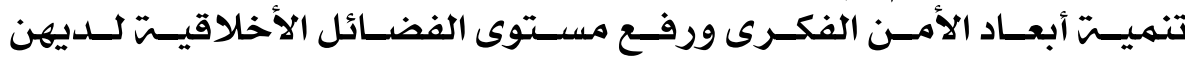

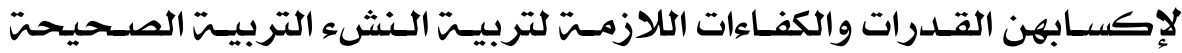

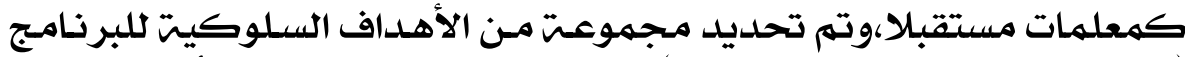

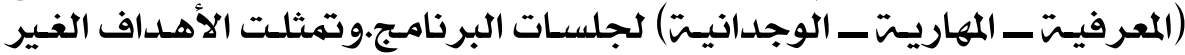

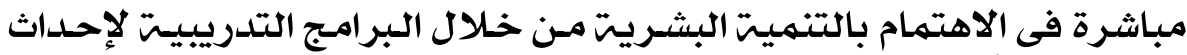

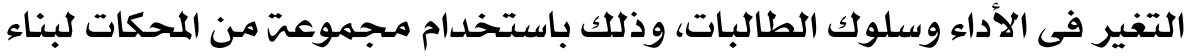

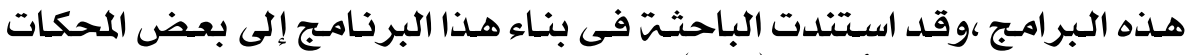
التى قدمتها صفاء الأعصر النسر (1999) وهى: 4 الأساس النظرى السليهم. 


\begin{tabular}{|c|c|c|c|}
\hline \multicolumn{4}{|c|}{ 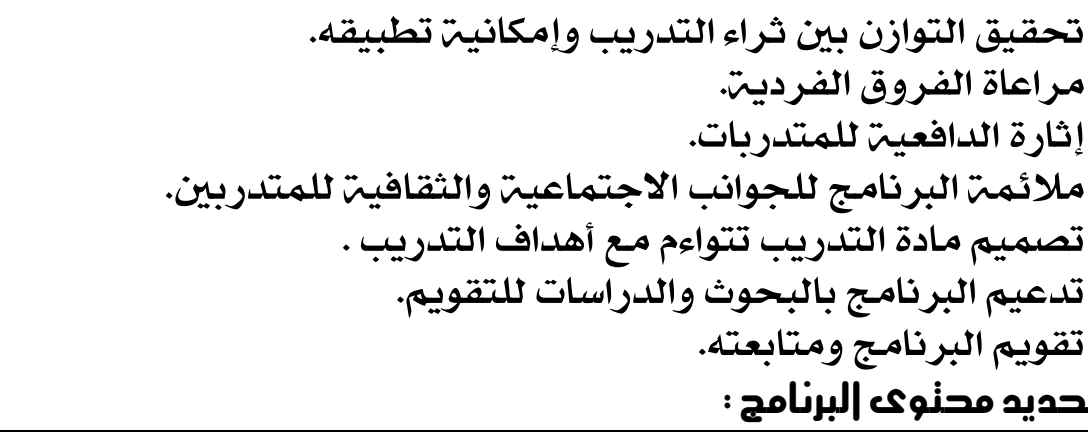 } \\
\hline كوناته & 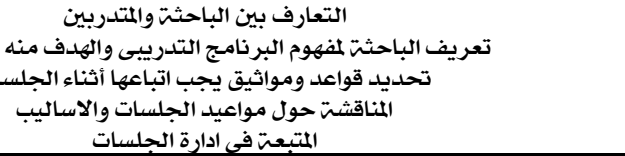 & لقاء تعارف & تقهيديت \\
\hline \multicolumn{4}{|c|}{ جلسات تنميت أبعاد الأمن الفكرى } \\
\hline الاستراتيجيات & أهدافها & موضوع الجلستر & الجلستم \\
\hline $\begin{array}{l}\text { الستراتيجيتة } \\
\text { الحوار والمناقشتشت }\end{array}$ & 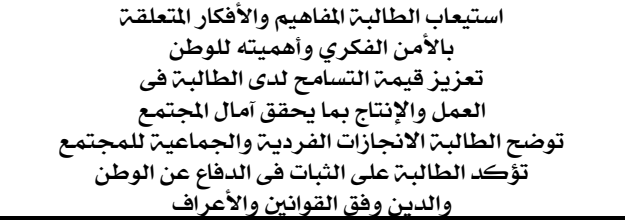 & الوطنى الانتماء & 1 \\
\hline الحب الادوار التخيل & 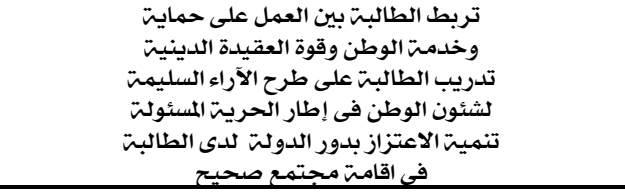 & للوانتماء & r \\
\hline الحب الادوار الحتار & 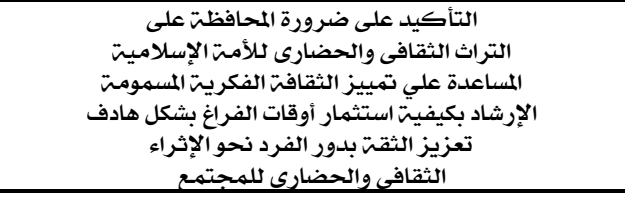 & الانتمافى الثقاء & r \\
\hline الحوار والمناقشتشت & 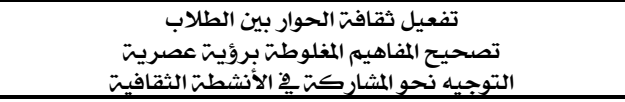 & الانتماء & $\varepsilon$ \\
\hline العب الادوار & 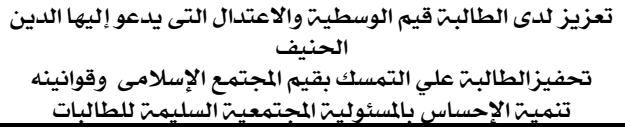 & والعقائدىى الانتماء & ○ \\
\hline العب الادوار & 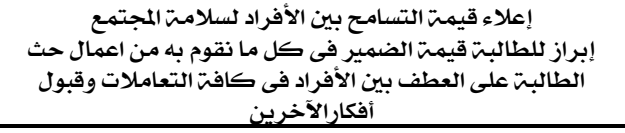 & 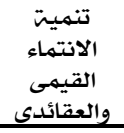 & 7 \\
\hline الحوار والمناقشار & 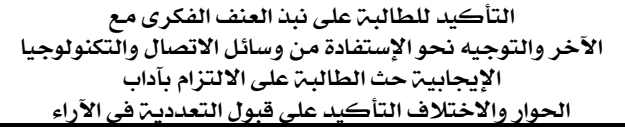 & الالانتمابى الائ & $v$ \\
\hline \multicolumn{4}{|c|}{$\begin{array}{r}Y_{1} \\
c_{2}=\end{array}$} \\
\hline
\end{tabular}




\begin{tabular}{|c|c|c|c|}
\hline \multicolumn{4}{|c|}{ والاتحاهات } \\
\hline الحوار والمناقشتّ & 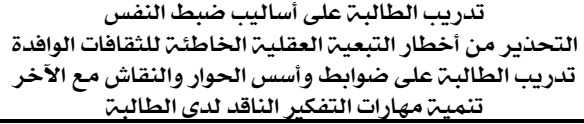 & الانتميتّاء & $\wedge$ \\
\hline \multicolumn{4}{|c|}{ جلسات تنميت الذكاء الأخلاقي } \\
\hline الاستراتيجيات & أهدافها & موضوع & الجلستم \\
\hline الحوار والمناقذت & 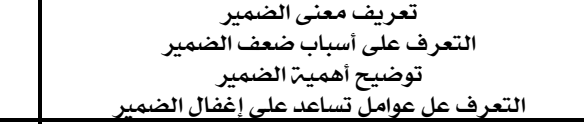 & معنى وأهميتة & 9 \\
\hline التحب الأخدوار & 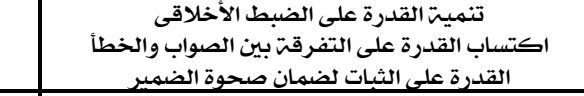 & وصنميتي & 1. \\
\hline الحوار والمناقشتّت & 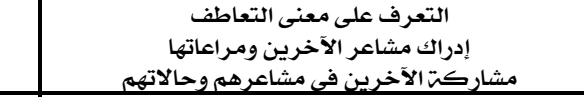 & معنى التعاطف & 11 \\
\hline 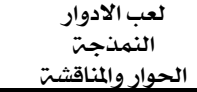 & مهمارست أساليب المساعداليب مساعدة للاخرين الاخرين & والتعاطاليب & ir \\
\hline 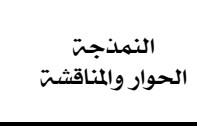 & 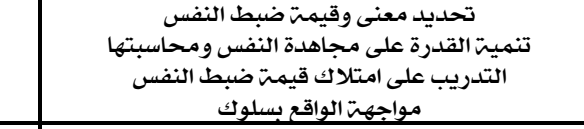 & قيمت ضبط النفس & Ir \\
\hline العب الأدوار التخيل & 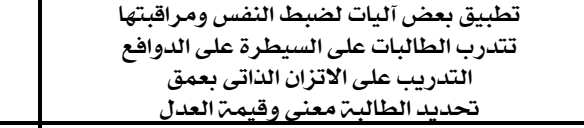 & ت ت تميتة ضبط & $1 \varepsilon$ \\
\hline الحوار والمناقشتة & 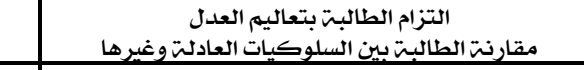 & قيمت العدل & 10 \\
\hline الحب التخيل & 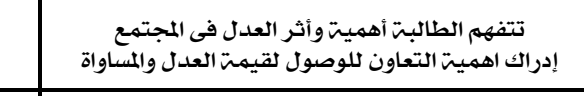 & ت تنميت العدل & 17 \\
\hline العب الأدوار & 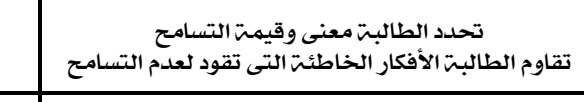 & قيمت التسامـح & IV \\
\hline العب الادوار & 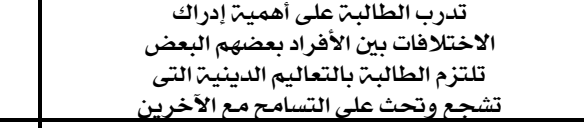 & قيمتميت التساعلاءح & $M$ \\
\hline الحوار والمناقشت التخيل & 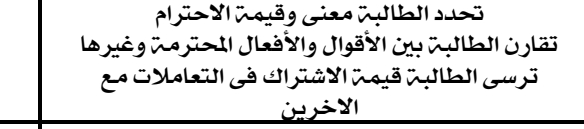 & قيمت الاحترام & 19 \\
\hline الحب الادوار & 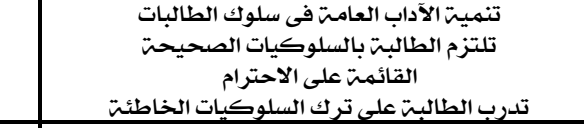 & ت ت الاحتيتراميمت & r. \\
\hline العب الادوار & 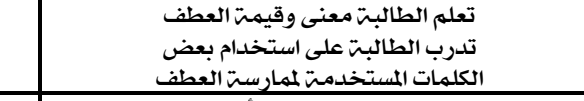 & قيمت العطف & rI \\
\hline العب الادوار & 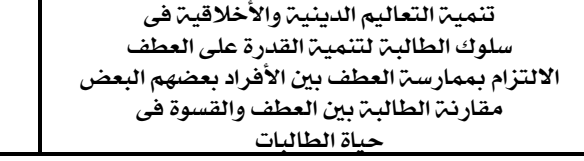 & تنميت العطف & rr \\
\hline \multicolumn{4}{|c|}{$\begin{array}{r}19 \\
c_{2}= \\
\end{array}$} \\
\hline
\end{tabular}




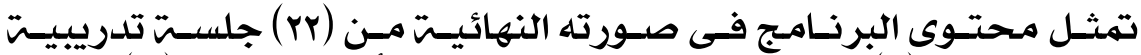

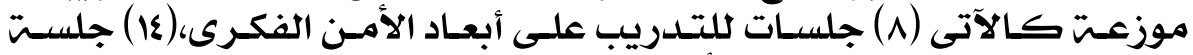

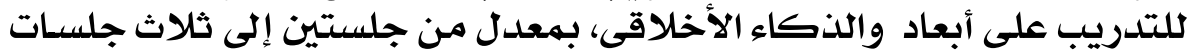

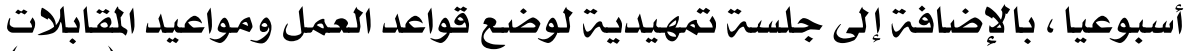

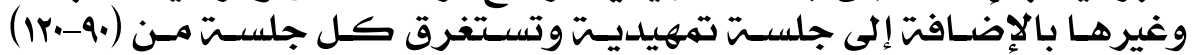

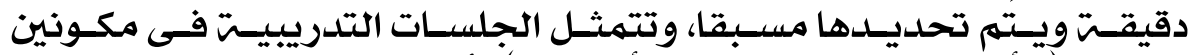

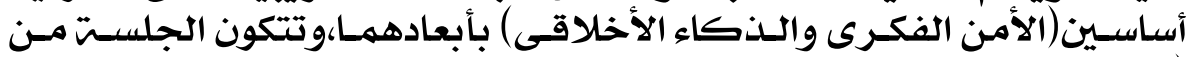

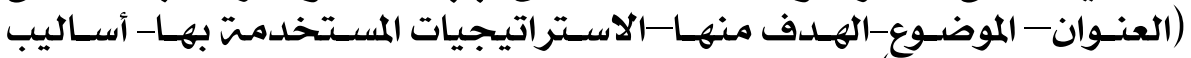

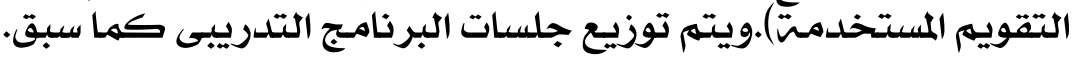

\section{• المواد والوسائل النعليمية المسنخدمة والإنشطة المخنارة:}

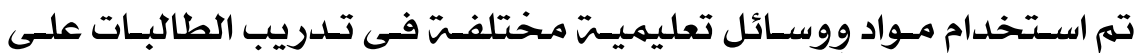

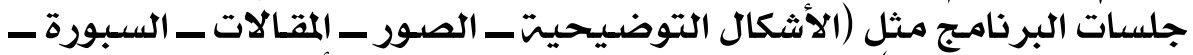

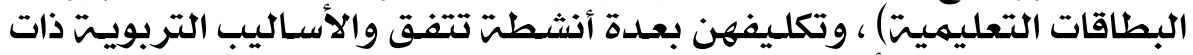

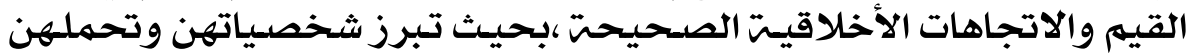

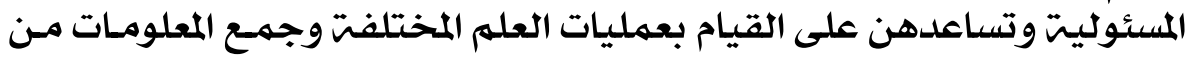
مصادر متعددة . متصاعل

\section{• الإستر|نيجيانه المسنخدمة :}

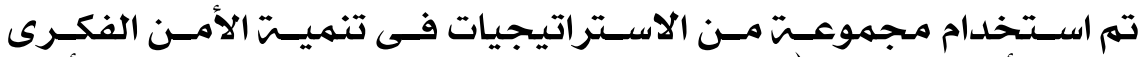

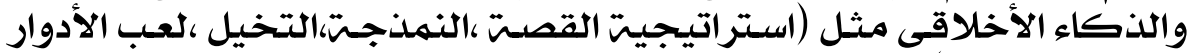
الحوار والمناقشتش).

\section{• أساليب نْويه جلسانه البرنامج :}

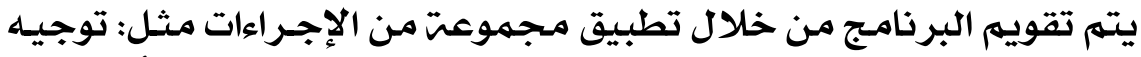

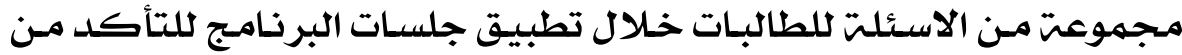

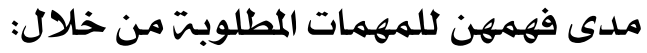

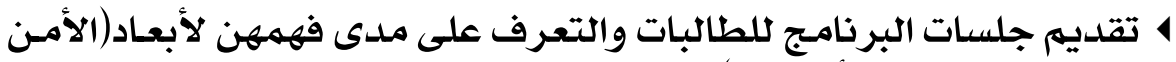

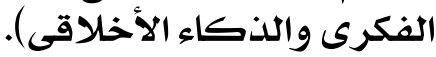

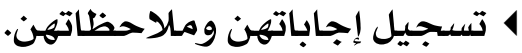

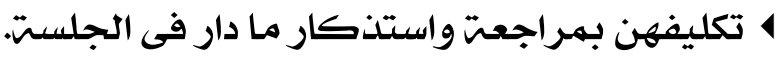

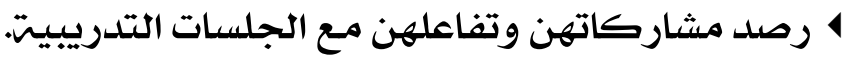
4

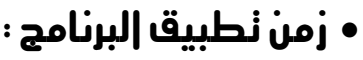

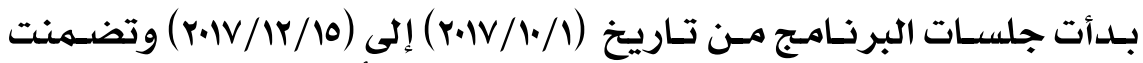

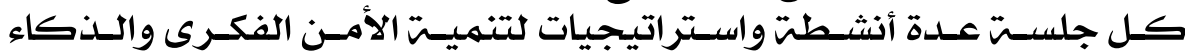
الأخلاقى فى ضوء تحلى هيات التربيت المستقبليتئ. r r. 
• صدق البرنامج الهقترح:

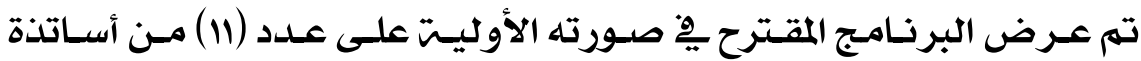

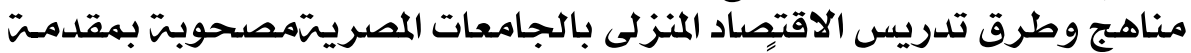

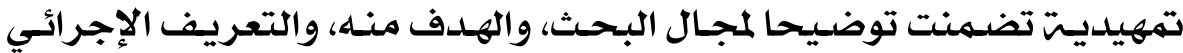

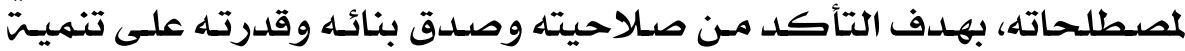

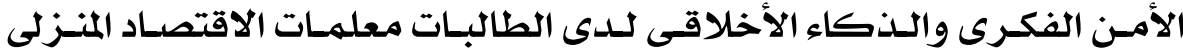

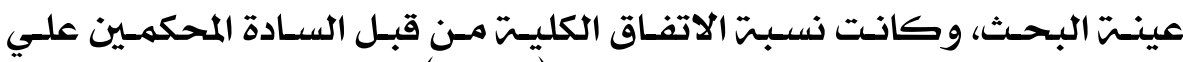

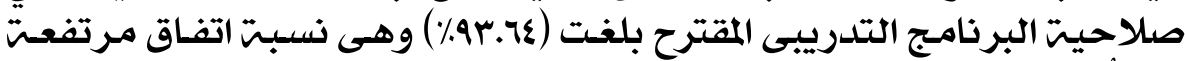

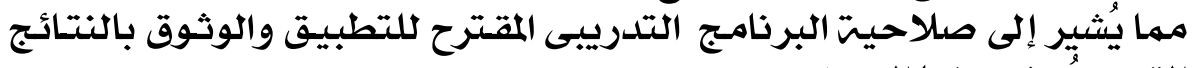
التى سيسفر عنها البحث.

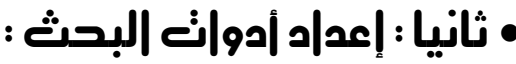

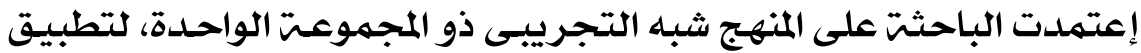

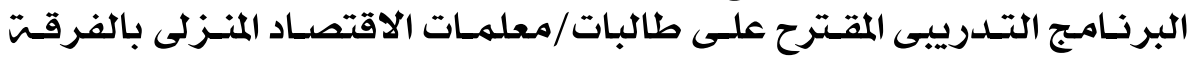

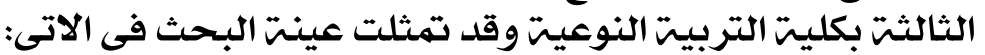
• العينة الاسنطالعية:

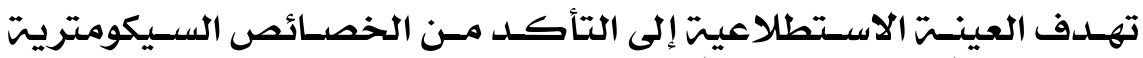

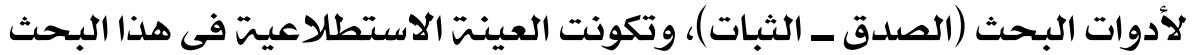

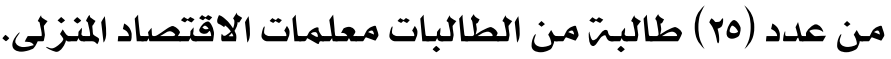

• العينة الأساسية:

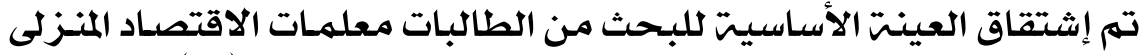

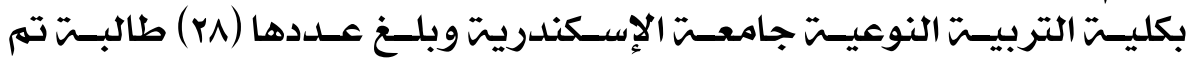

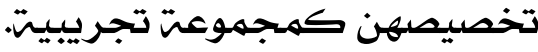

\section{• مقياس الأمن الفكرع: [ [إعد|د / الباحثة]}

\section{• الهدفع من الهقياس:}

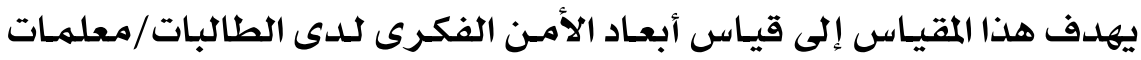

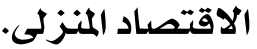

\section{• وصفع المقياس:}

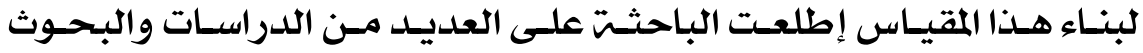

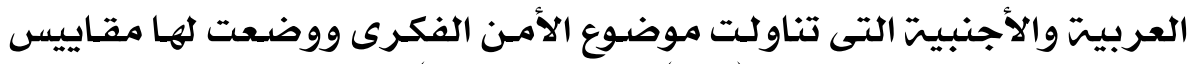

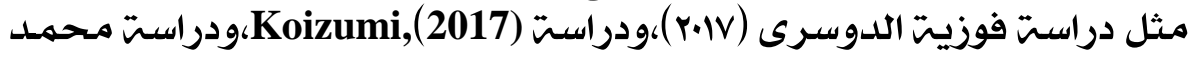

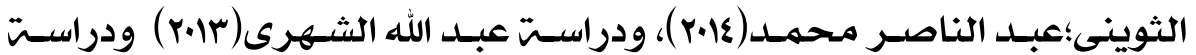
Y و 


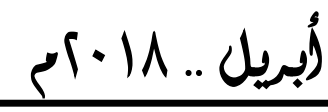

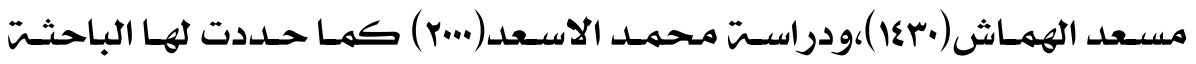

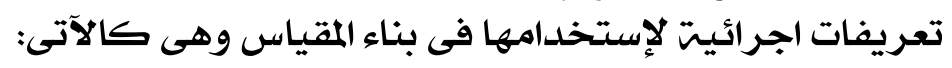

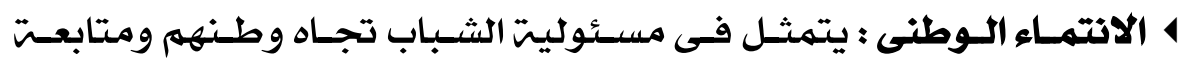

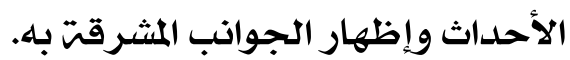

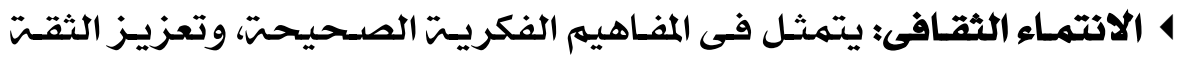

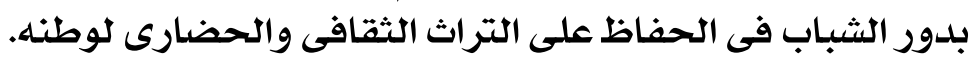

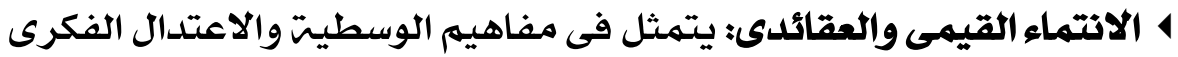

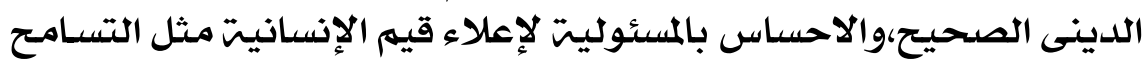

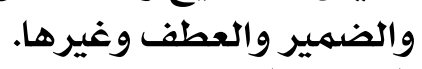

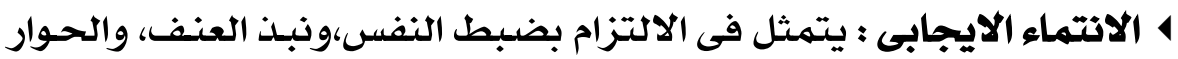

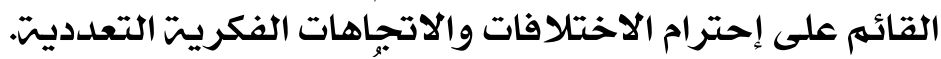

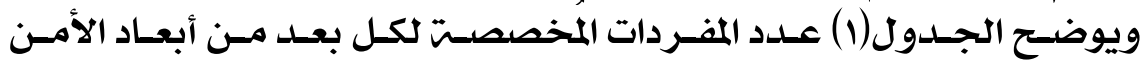

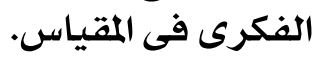

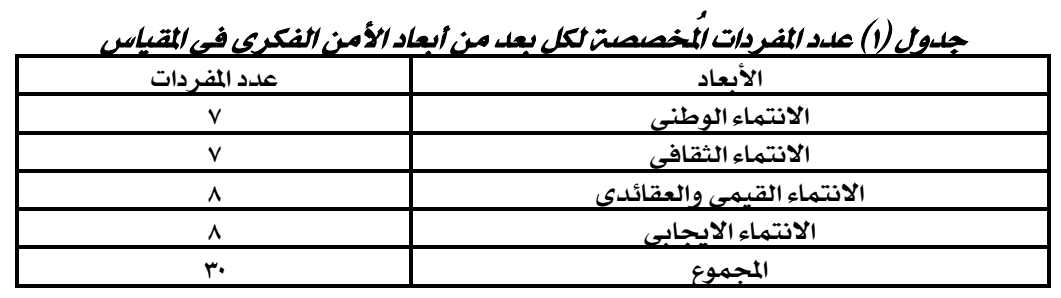

• صدق المقياس:

\section{• صدق المحكمين وصدق المحنوي للإوشي:}

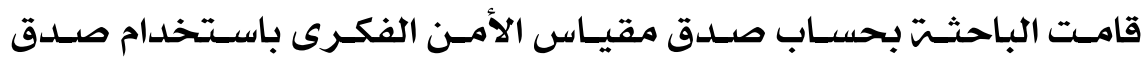

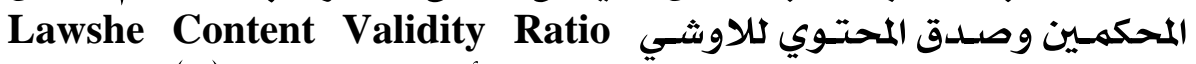

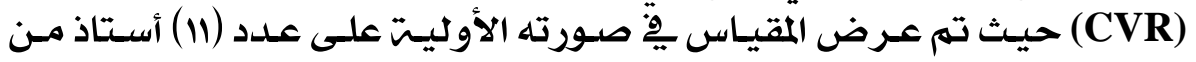

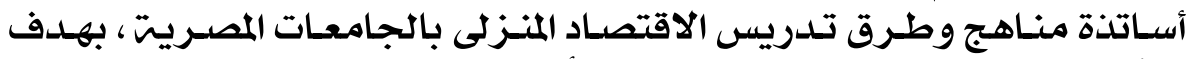

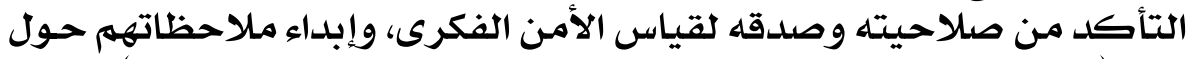

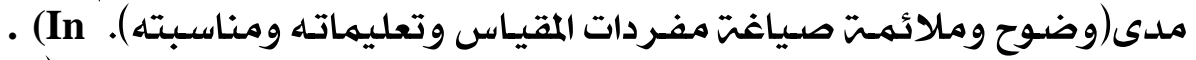

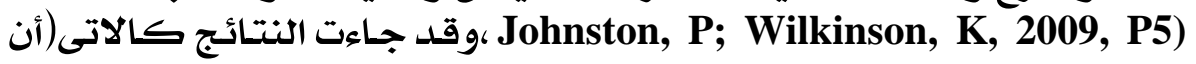

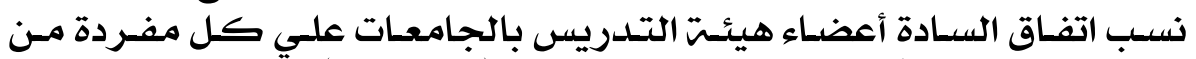

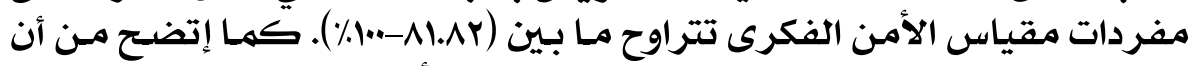

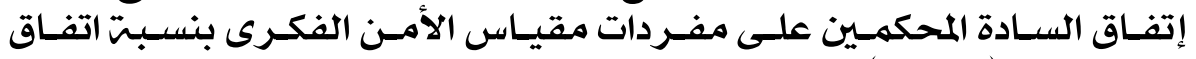

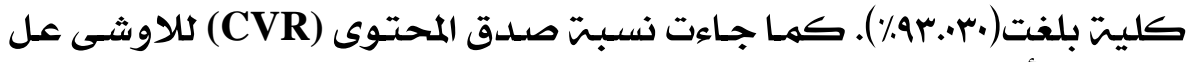

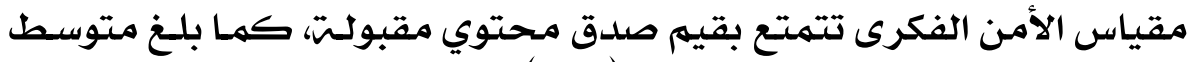

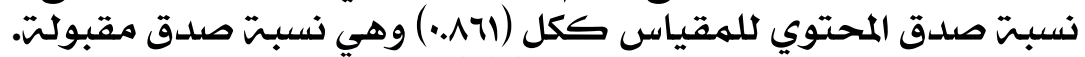
YYY ace 


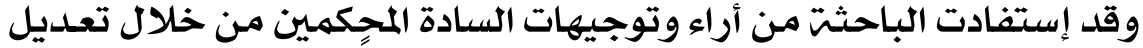

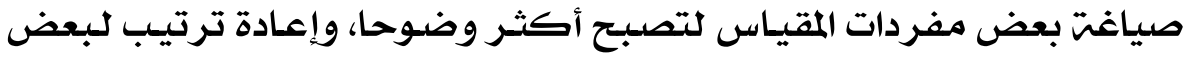
المفردات بتقديه بعضها على بعض بعرديات

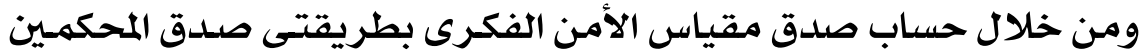

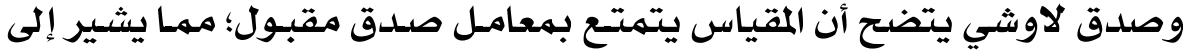

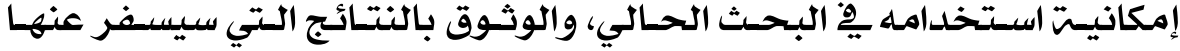

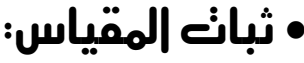

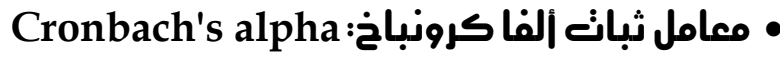

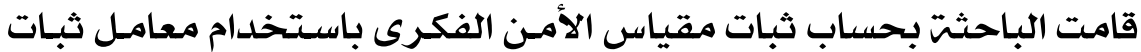

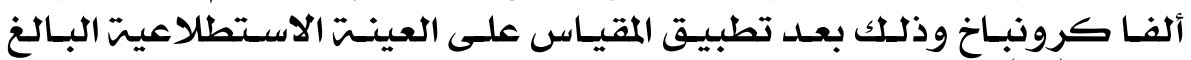

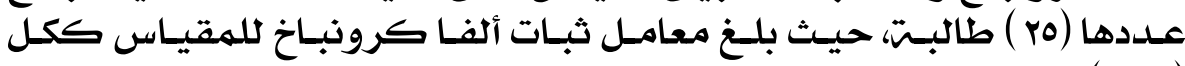

\section{• معامل ثبانه إعادة النطبيق: Test- Retest}

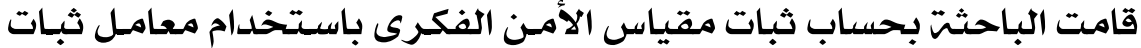

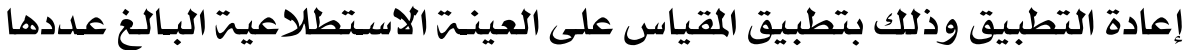

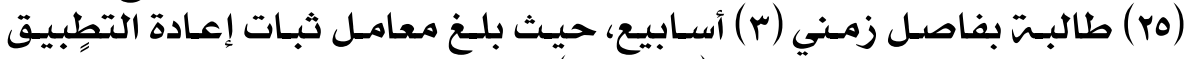

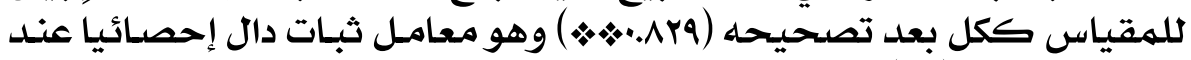

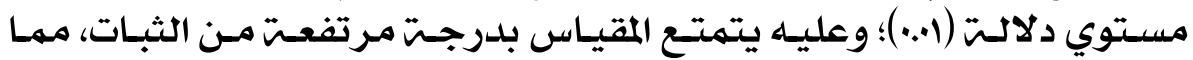

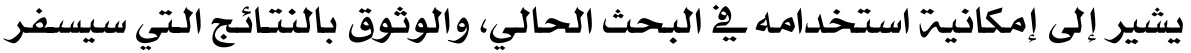

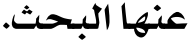

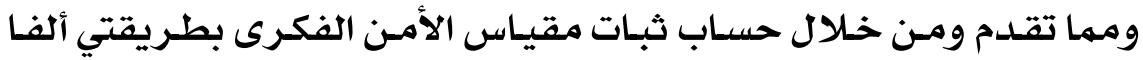

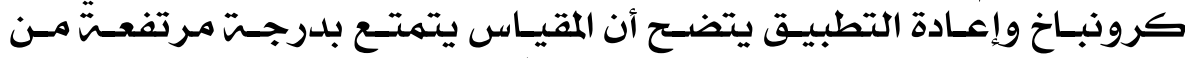

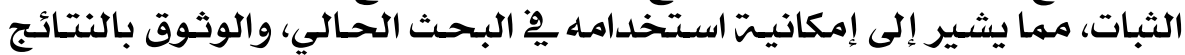

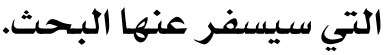

• زمن الهقياس:

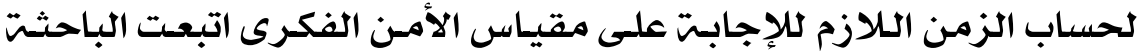

الخطوات الآتيت: الزين

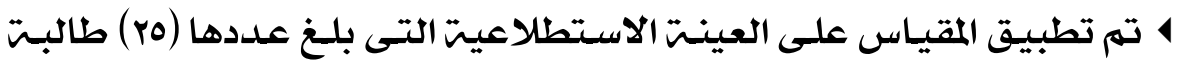

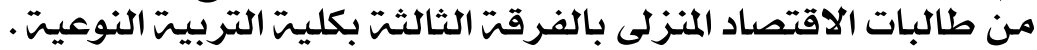

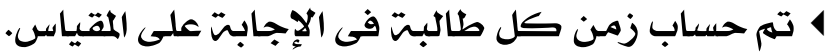

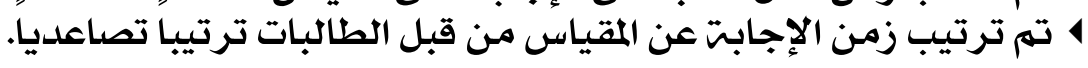
rrr 


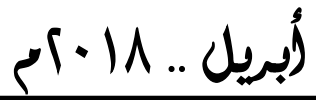

4 تم فصل زمن الإرباعى الأعلى (YV/\%) من العينت الاستطلاعيت كذلكك زمن

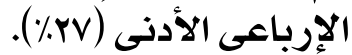

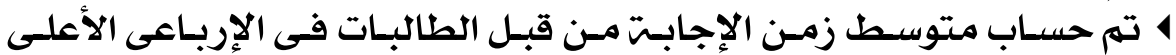
والطالبات فى الإرباعى الأدنى.

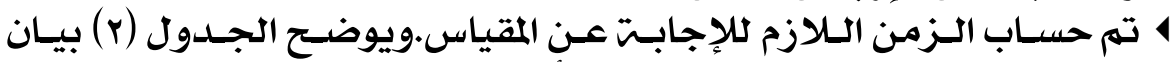

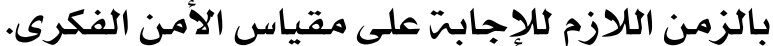

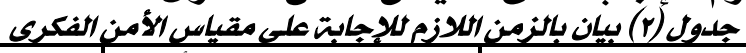

\begin{tabular}{|c|c|c|c|}
\hline زمن الإجابة & متوسط زمن الإرباعى الأدنى 1 (ن) & متوسط زمن الإرباعى & المتغغير \\
\hline r.r.r دقيقت & & 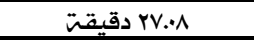 & آز \\
\hline
\end{tabular}

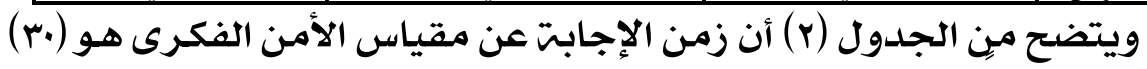
دقيقت تقريبا.

\section{• ن ن نصحيح الهقياس:} تم تصديح المقيـاس طبقـا لتـدريج ليكرت الخماسى كمها يوضـح الجـدول

جلول (r) طريقت تصحيح مقياس الأمن الفكرى

\begin{tabular}{|c|c|c|c|c|c|}
\hline \multicolumn{5}{|c|}{ مستويات الموافقت والدرجات المستحقة } & \multirow[b]{2}{*}{ المتغيرات } \\
\hline غير موافق بشدة & غير موافق & محايد & موافق & موافق بشدة & \\
\hline 1 & $r$ & $r$ & $\varepsilon$ & 0 & الدرجت المستحقتة \\
\hline \multicolumn{5}{|c|}{10.} & النهايت العظمي للمقياس \\
\hline & & 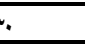 & & & النهايت العظمي للهقياس \\
\hline
\end{tabular}
• الهدفع من الإخنبار:

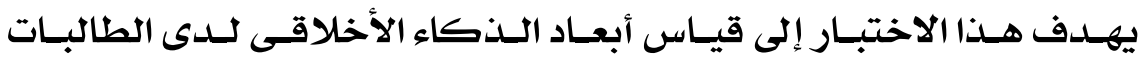
/معلمات الاقتصاد المنزلى. • وصفع الإخنبار:

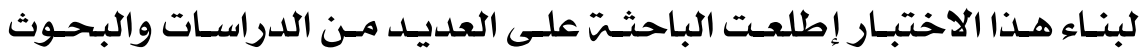

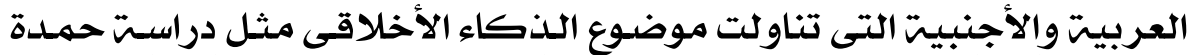

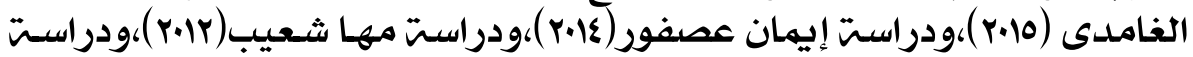

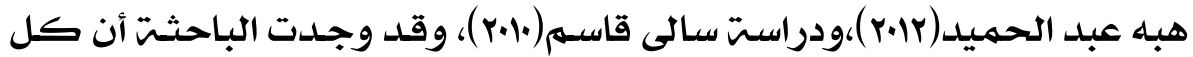

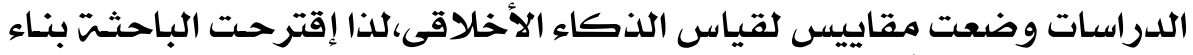

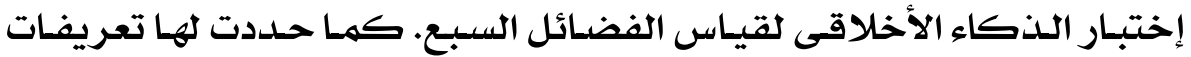

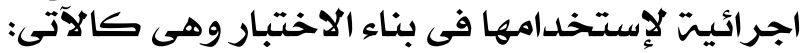

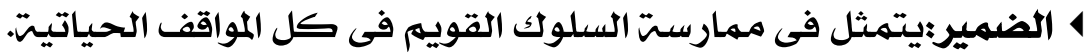

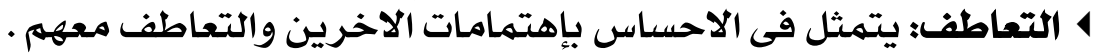




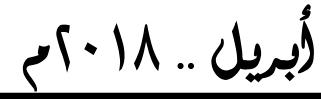

\ ضبط الـنفس: يتمثل في القـدرة على تتظيهم الافكـار والتصـرف بثبـات و وصدق.

4 الاحترام : يتمثل فى تقدير الآخرين وكيفيت التعامل معهمه .

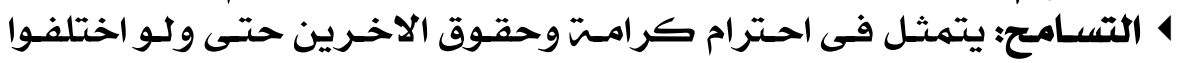
معها .

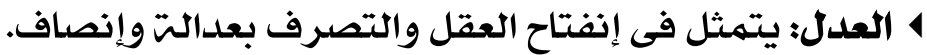

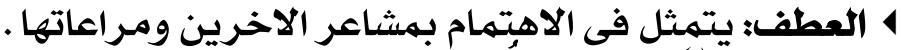

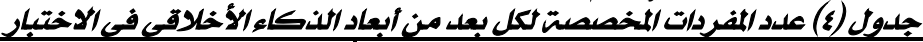

\begin{tabular}{|c|c|}
\hline عدد المفردات & الأبعاد \\
\hline$\varepsilon$ & الضمير \\
\hline$r$ & التعاطف \\
\hline$r$ & ضبط النفس \\
\hline$r$ & الاحترام \\
\hline$\varepsilon$ & التسامح \\
\hline$r$ & العدل \\
\hline$r$ & العطف \\
\hline r. & المجموع \\
\hline
\end{tabular}

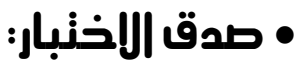
• صدق الهحكمين وصدق المحنوي للإوشيب:

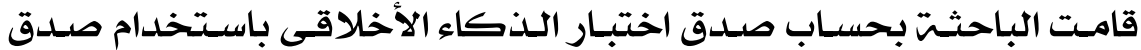

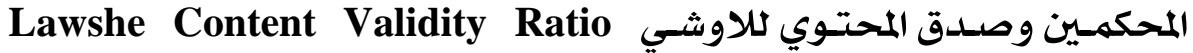

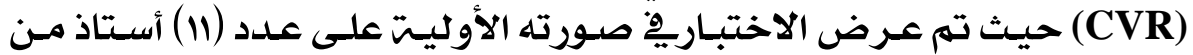

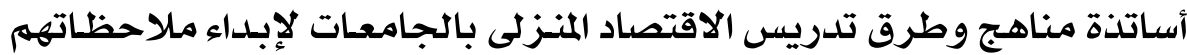

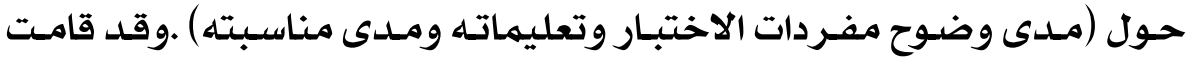

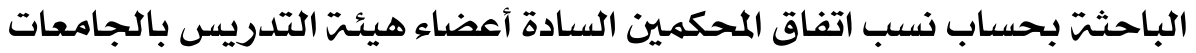

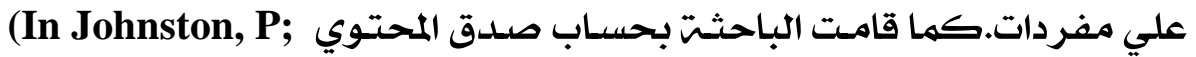

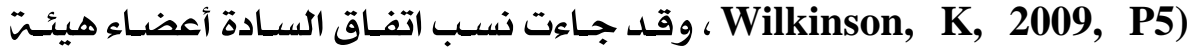

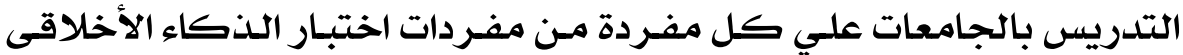

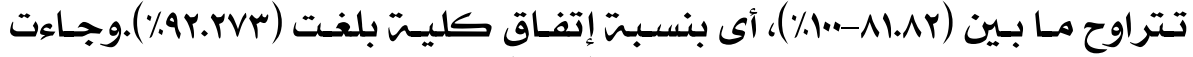

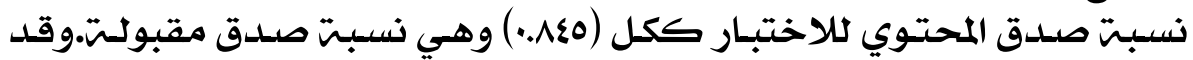

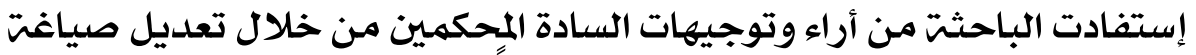

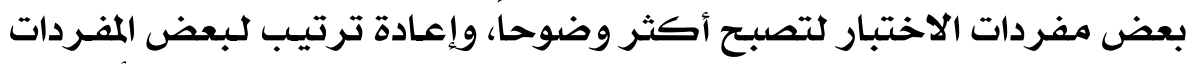

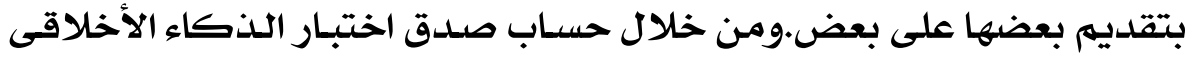

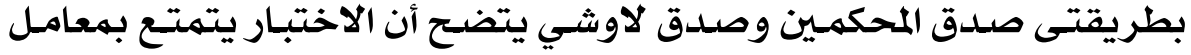

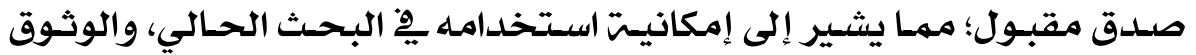

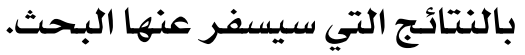




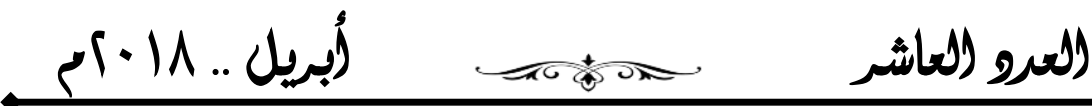

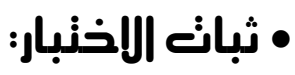

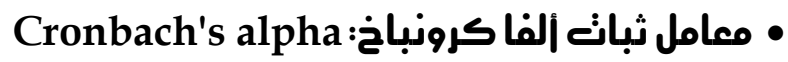

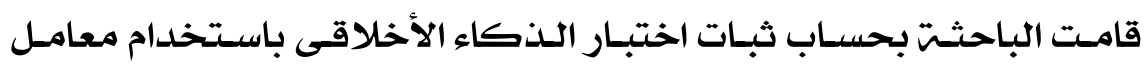

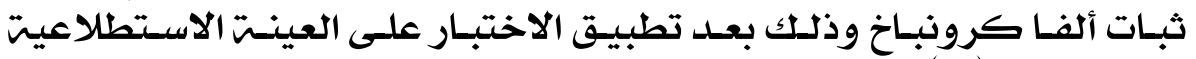

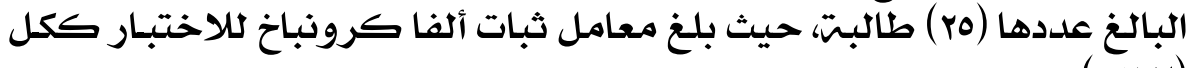

\section{• معامل ثبانه إعادة النطبيق: Test- Retest}

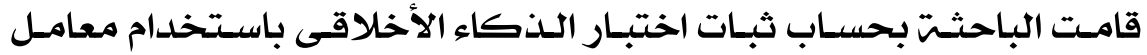

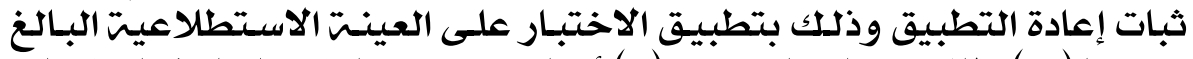

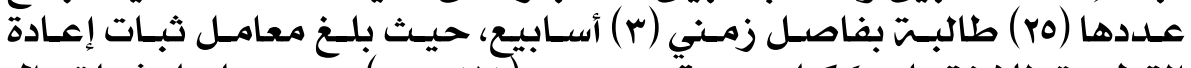

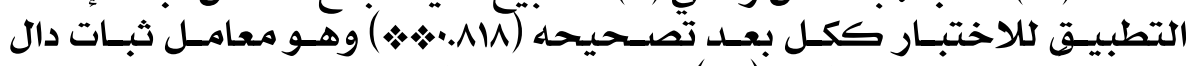

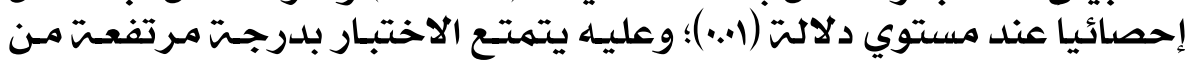

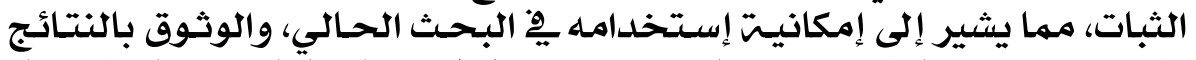

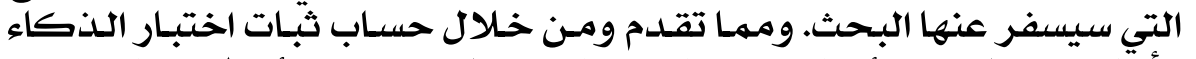

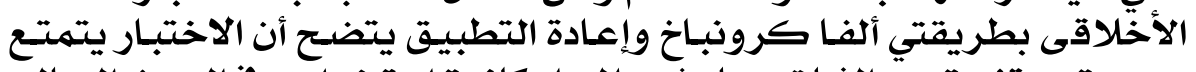

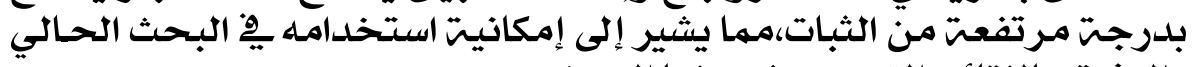
والوثوق بالنتائج التي سيسفر عنها البحثي

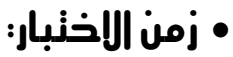

لحساب الزمن الكلازم للإجابت على اختبار الذكاء الأخلاقى اتبعت الباحثت

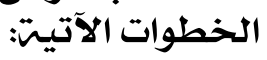
1 تم تطبيق الاختبار على العينـت الاستطلاعيتّ التى بلـغ عددها (ب) طالبـت بالفرقت الثالثت. 4 تم حساب زمن كل طالبت طالبت في الإجابت على الاختبار.

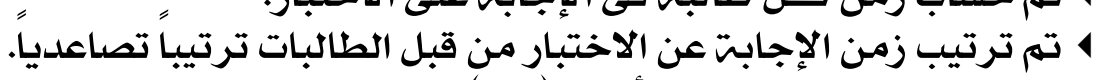

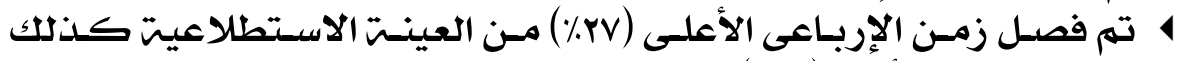

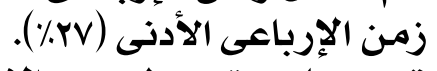

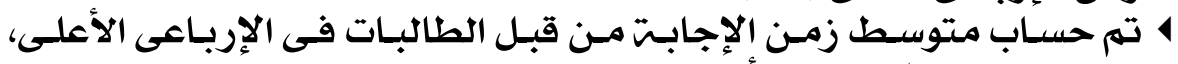

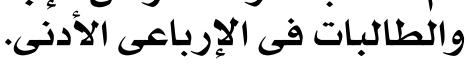

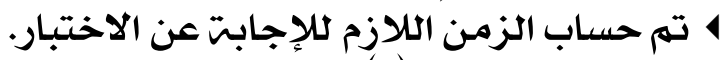

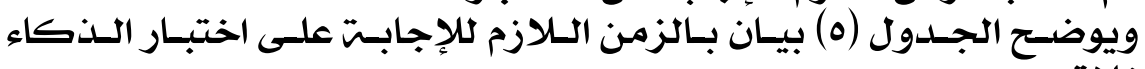

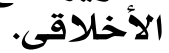

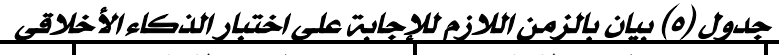

\begin{tabular}{|c|c|c|c|}
\hline زمن الإجابتابت عن & 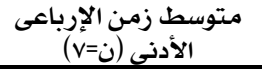 & 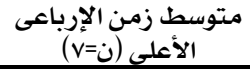 & المتغير \\
\hline 人ـ..ع دقيقت & 7.04؛ دقيقت & q.. דr دقيقت & الزمن \\
\hline
\end{tabular}

$\mathrm{Cus}_{2}$

\section{حوع عربية خي مجالات التربية النوعية}


يتضح من الجدول (ه) أن زمن الإجابت عن إختبار الذكاء الأخلاقى هـو(ع) دقيقت تقريبا.

\section{• ن نصحيح الإخنبار:}

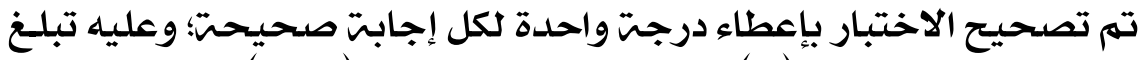

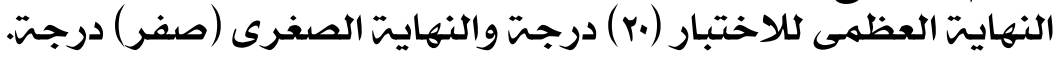

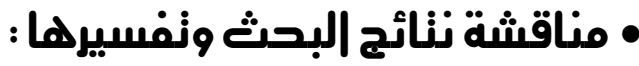

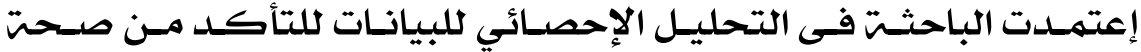

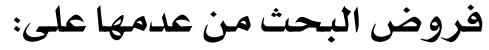

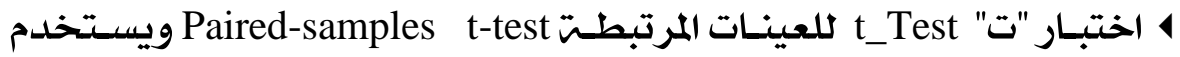

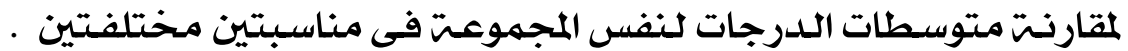
(Pallant, J, 2007, P232)

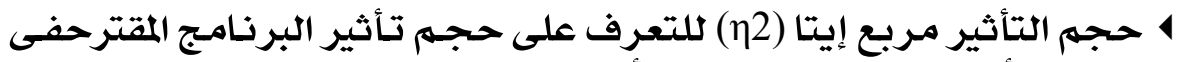

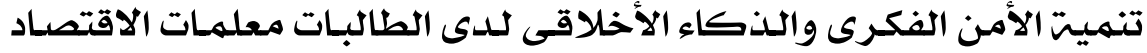

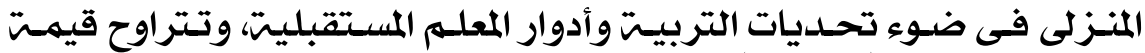

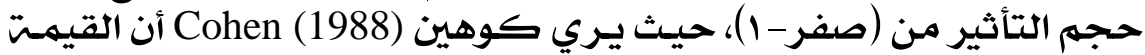

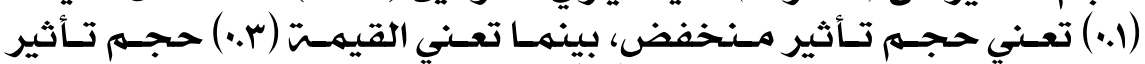

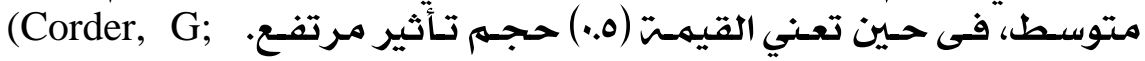
, 2009, p59)Foreman, D

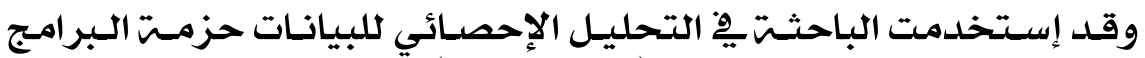

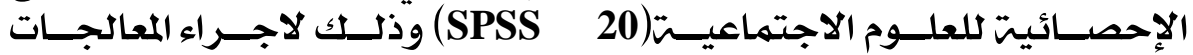

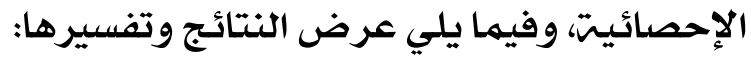

\section{• إخنبار صحة الفرض الأول:}

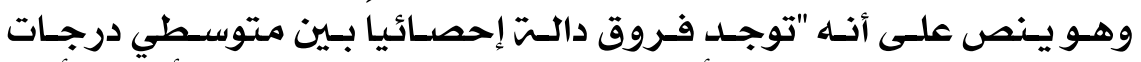

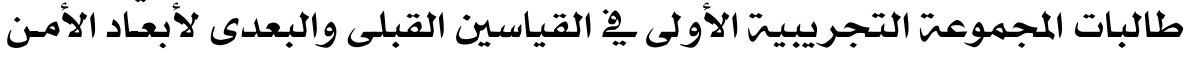

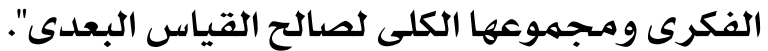

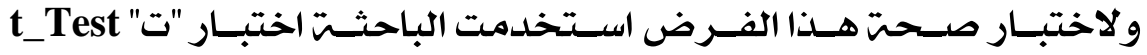

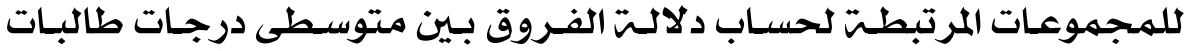

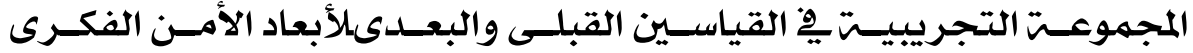

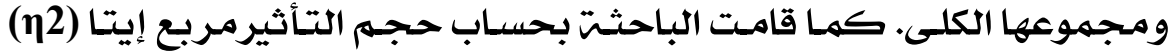

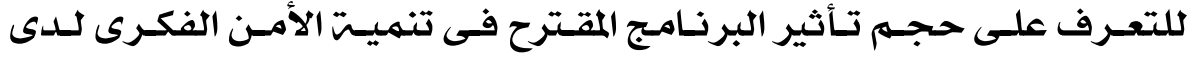

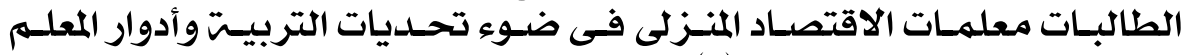
المستقبليت، موضححه بالجدول معلهات (7): 


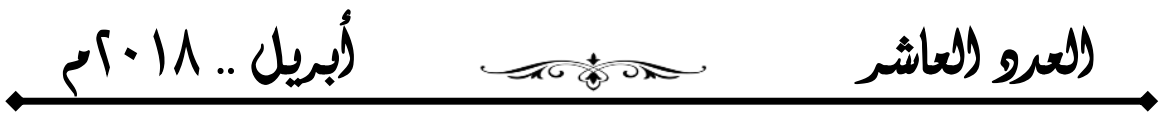

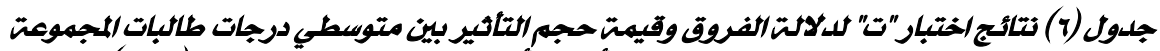

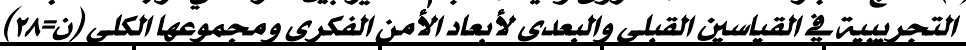

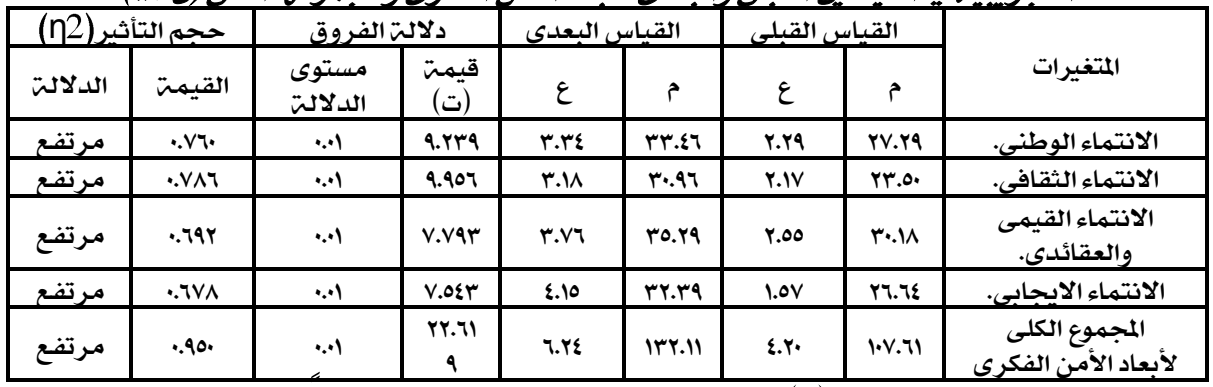

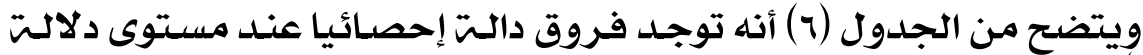

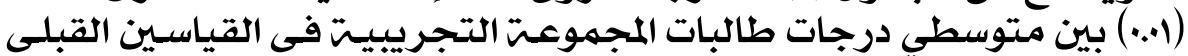

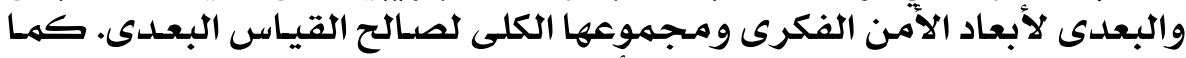

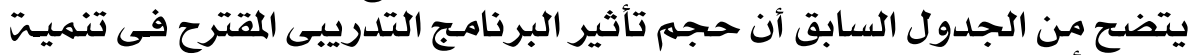

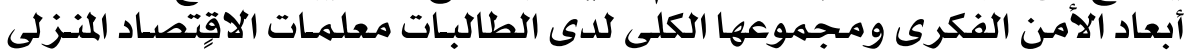

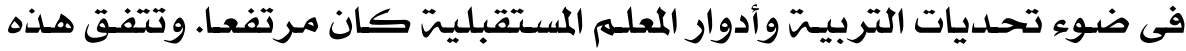

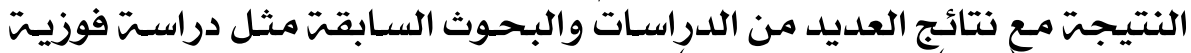

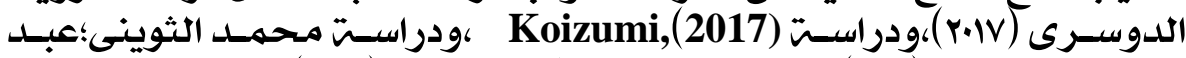

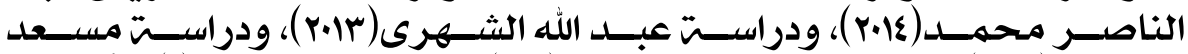

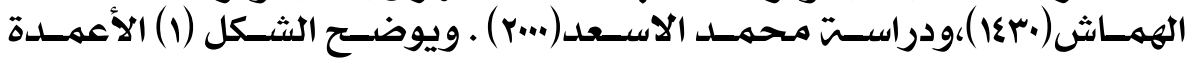

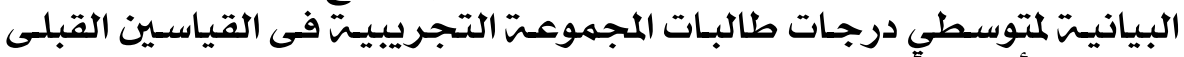

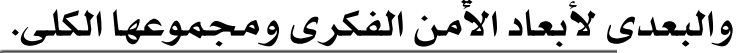

|القبانس الإبلى

القباسن البعدى

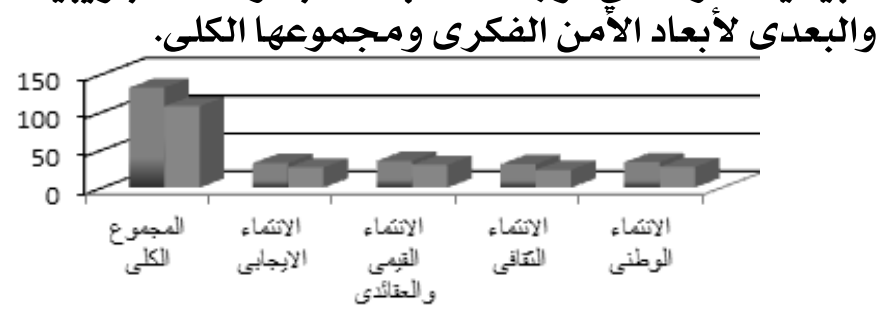

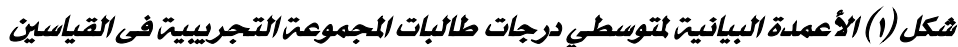

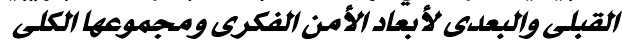

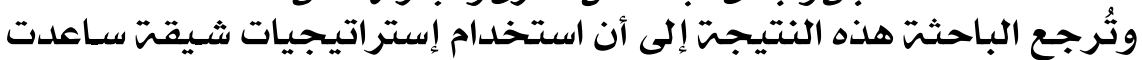

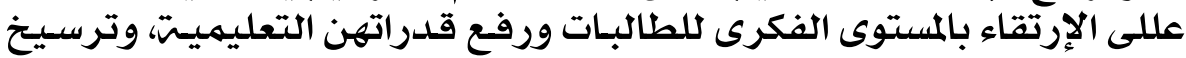

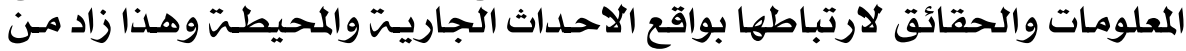

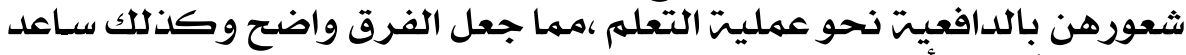

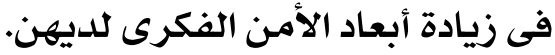
• اخنبار صحة الفرض الثانه:

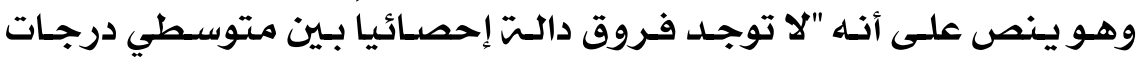

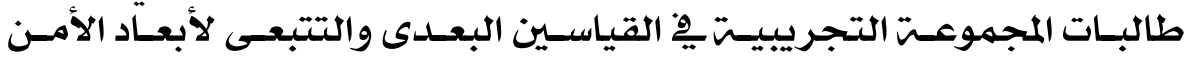

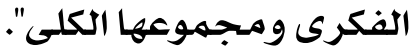

Y YA

$\mathrm{Cr}_{2}$

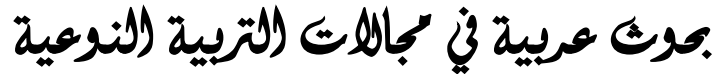




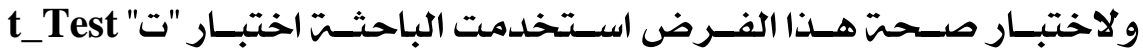

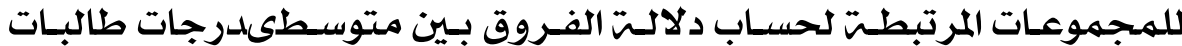

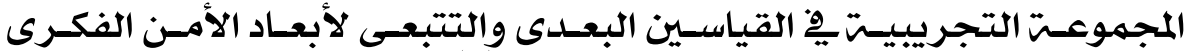

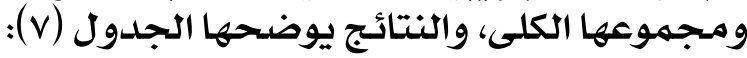

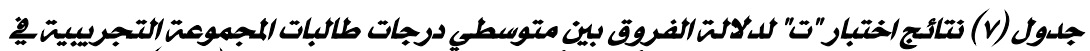

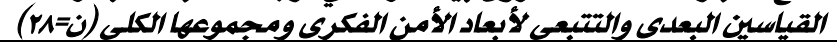

\begin{tabular}{|c|c|c|c|c|c|c|}
\hline \multicolumn{2}{|c|}{ دلالت الفروق } & \multicolumn{2}{|c|}{ القياس التبعى } & \multicolumn{2}{|c|}{ القياس البعدي } & \multirow{2}{*}{ المتغيرات } \\
\hline مستوى الدلالتي & قيمتة (ت) & $\varepsilon$ & s & $\varepsilon$ & 5 & \\
\hline غير دالت & . & r.Vr & $r \xi . . \xi$ & r.re & rr.s7 & الانتمـاء الوطنى. \\
\hline غير دالت & .941 & $\varepsilon . \varepsilon Y$ & r1. & $\mathrm{r.1N}$ & $r .97$ & الانتماء الثقافي. \\
\hline غير دالت & $\cdot . \Sigma Y \wedge$ & T.Y. & rะ.人T & r.vi & ro.rq & الانتماء القيمى والعقدي. \\
\hline غير دالت & $1.07 \varepsilon$ & \&.rV & rr.ll & $\$ .10$ & rY.rq & الانتماء الايحابي. \\
\hline غير دالت & •^А५ & $9.7 \%$ & EIr.TE & T.Y乏 & Irr.II & لأبعاد الأمّن الفكرى الكلى \\
\hline
\end{tabular}

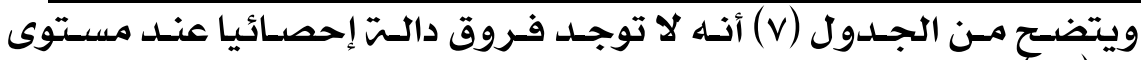

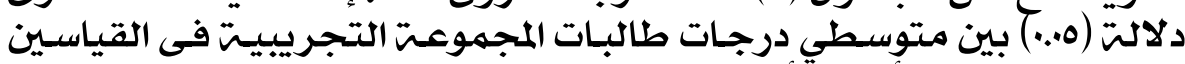

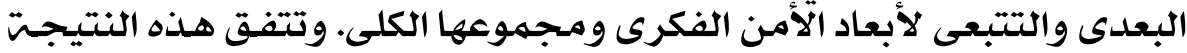

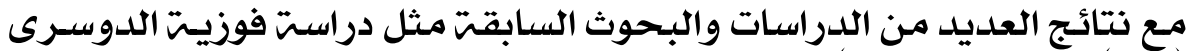

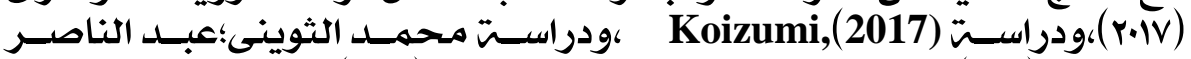

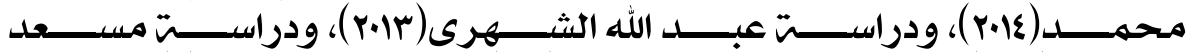

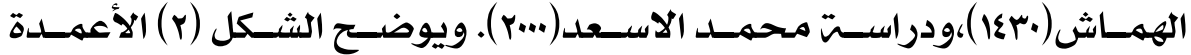

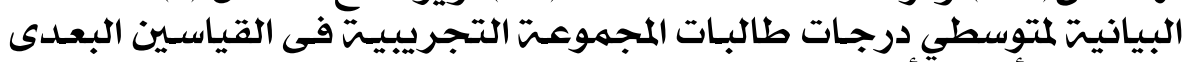

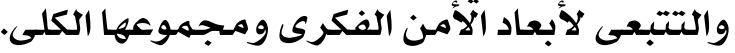

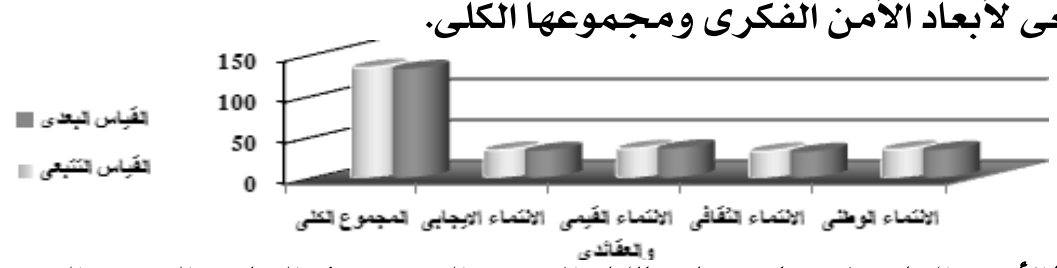

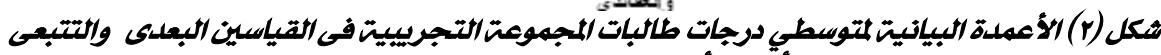

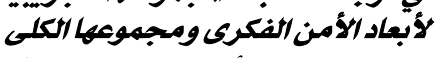

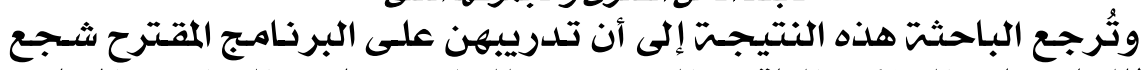

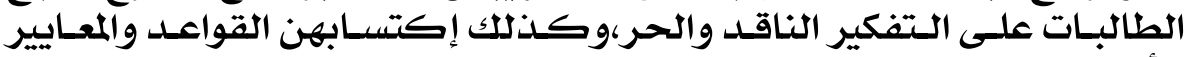

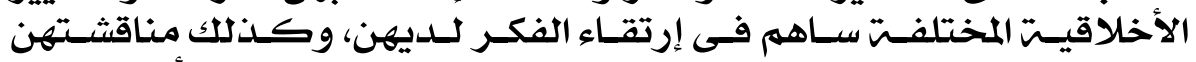

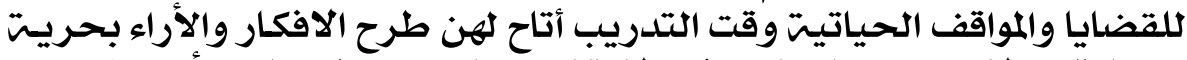

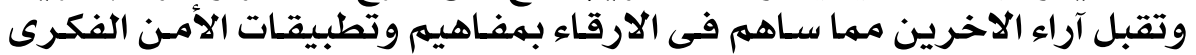
بقبول وراحت.

\section{• اخنبار صحة الفرض الثالث:}

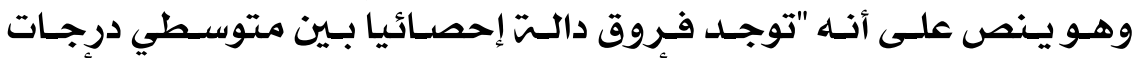

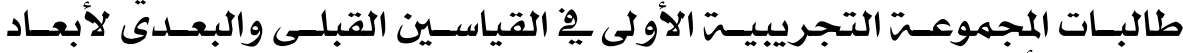

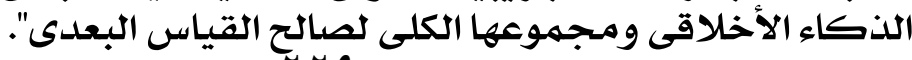
r P 


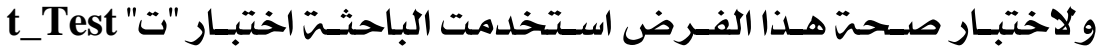

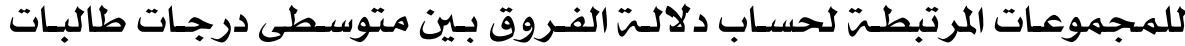

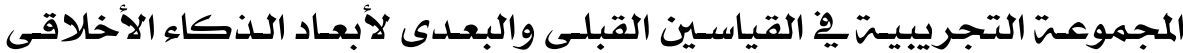
و ومجموعها الكلى.

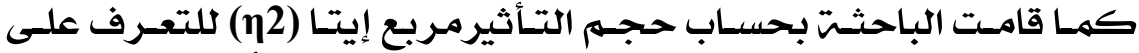

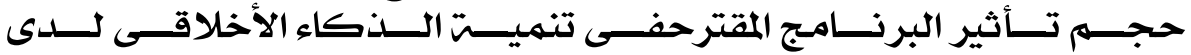

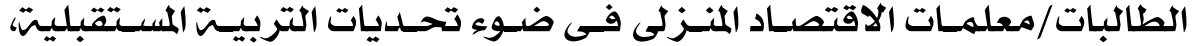

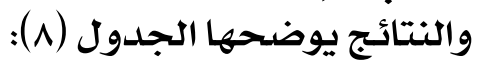

جلدول (1) نتائج اختبار"ت" للالالت الفروق وقيهت حجم التأثير بين متوسطي درجات طالبات المجموعت

\begin{tabular}{|c|c|c|c|c|c|c|c|c|}
\hline \multicolumn{2}{|c|}{ حجم التأثير(n2) } & \multicolumn{2}{|c|}{ دلالت الفروق } & \multicolumn{2}{|c|}{ القياس البعدى } & \multicolumn{2}{|c|}{ القياس القبلي } & \multirow[b]{2}{*}{ المتغيرات } \\
\hline الدلالت & القيمتة & مستوى الدلاتت & قيمتش & $\varepsilon$ & $\hat{r}$ & $\varepsilon$ & $\hat{\imath}$ & \\
\hline مرتفع & גדו.. &. .1 & V.rY & .10 & $r .1 \varepsilon$ & $1.1 \%$ & $1 . r 1$ & الضمير \\
\hline مرتفع & .791 &. .1 & V.VVA &.$\vee \vee \wedge$ & Y.T\& & $1 . . Y$ & $1.0 V$ & التعاطف \\
\hline مرتفع & $.70 \mathrm{r}$ & $\because .1$ & V.1r9 & $.7 \mathrm{~V}$ & $r . \wedge r$ & 1.4 & 1.11 & ضبط النفسر \\
\hline متوسط & $. \varepsilon . Y$ & $\because .1$ & $\varepsilon . Y T \varepsilon$ & .70 & $1 . v 0$ & 1.9 &.$\wedge Y$ & الاحترام \\
\hline مرتفع & $.0 \mathrm{Vr}$ &. .1 & $7 . . . Y Y$ & $1 .\{\varepsilon$ & r.rY & 1.rA & $1 . r 9$ & التسامـح \\
\hline متوسط & $. \varepsilon . \varepsilon$ &. .1 & \&.YVV & .77 & 1.11 & 1 & .97 & العدل \\
\hline مرتفع & .7 .0 & $\because .1$ & $7 . \& \mathrm{rV}$ & .00 & $1 . \wedge r$ & $\cdot \wedge \cdot$ & .14 & العطف \\
\hline مرتفـع & $\bullet \wedge \Lambda \vee$ & $\because .1$ & $18.07 \mathrm{~V}$ & $r \cdot r$ & $|V . r|$ & $\{.01$ & V.rr & المجموعاء الأخلى لأبعادي \\
\hline
\end{tabular}

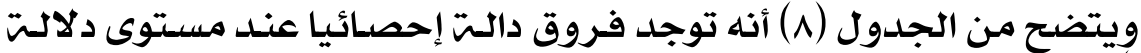

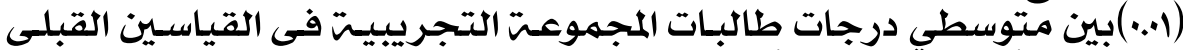

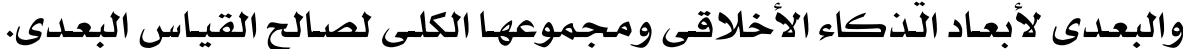

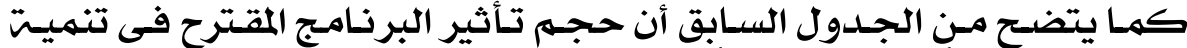

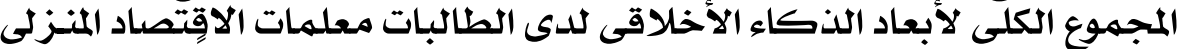

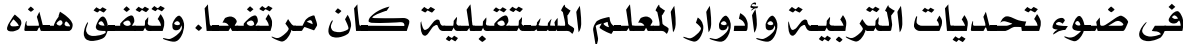

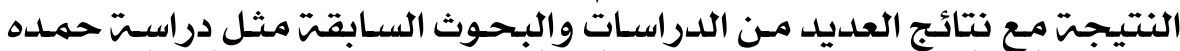

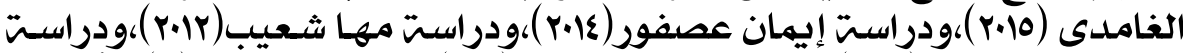

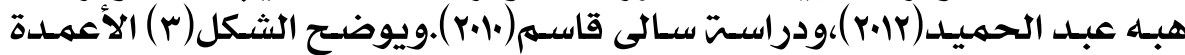

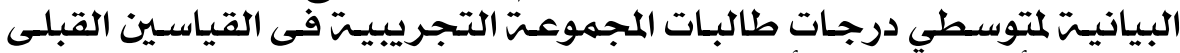

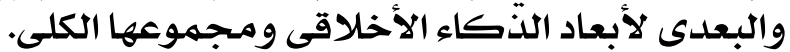

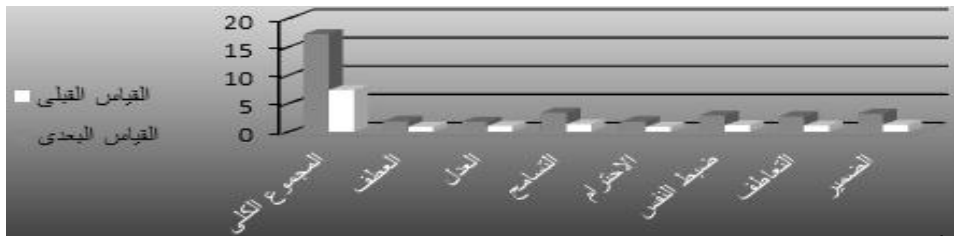

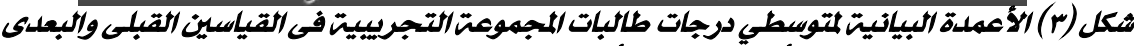
لأبعاذ النذاء الأخلاقى ومجهموعها الكليى

rr.

$\mathrm{Cr}_{2}$ 


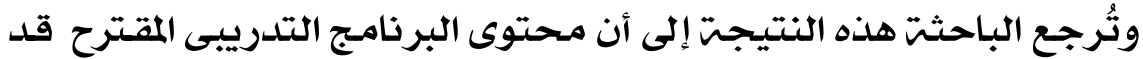

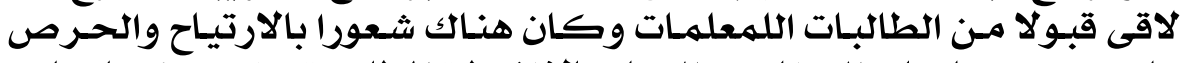

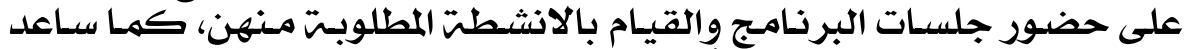

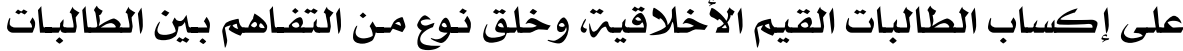

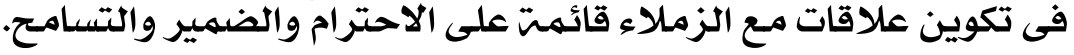

\section{• اخنبار صحة الفرض الرابع:}

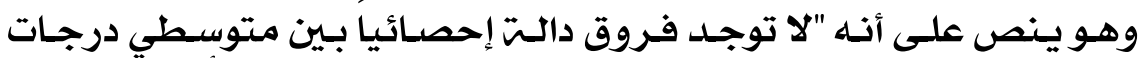

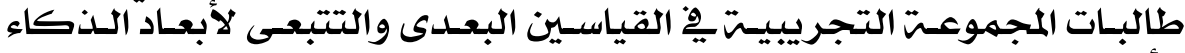
الأخلاقى ومهجموعها المجوعن الكلى".

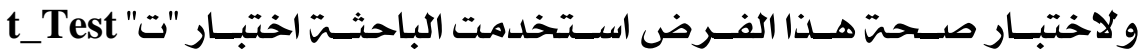

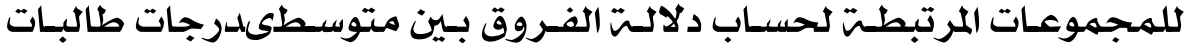

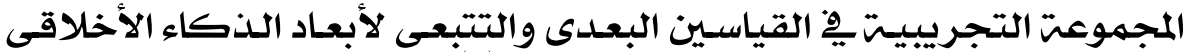

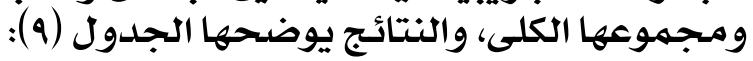

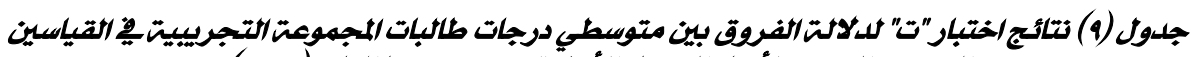

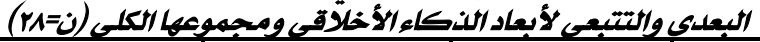

\begin{tabular}{|c|c|c|c|c|c|c|}
\hline \multicolumn{2}{|c|}{ دلالت الفروق } & \multicolumn{2}{|c|}{ القياس التتبعى } & \multicolumn{2}{|c|}{ القياسي البعدى } & \multirow{2}{*}{ المتغيرات } \\
\hline مستوى الدلالة & قيهت (ت) & $\varepsilon$ & ح & $\varepsilon$ & م & \\
\hline غير دالت & .099 &.$\wedge 9$ & r.ro & .10 & r.1\& & الضمير \\
\hline غير دالت & $1.0 \wedge \varepsilon$ & $\cdot .10$ & r.Yq &.$\vee V \Lambda$ & Y.T乏 & التعاطف \\
\hline غير دالت & .0990 & .91 & Y..$\varepsilon$ & $.7 \mathrm{~V}$ & Y.AY & ضبط النفس \\
\hline غير دالت & .719 &.. $\mathrm{Vr}$ & $1.7 \varepsilon$ & .70 & 1.10 & الاحترام \\
\hline غير دالت & 政Y & $1.0 \mathrm{~V}$ & r..\& & $1 . \leqslant \varepsilon$ & r.Mr & التسـامح \\
\hline غير دالت & $\therefore \wedge \leqslant 9$ & $.0 Y$ & $1 . \wedge 7$ & .77 & 1.11 & العدل \\
\hline غير دالت &.$\wedge 91$ & $.7 \mathrm{~V}$ & 1.71 & .00 & $1 . \Lambda Y$ & العطف \\
\hline غير دالت & דודא.• ( & $r .10$ & $17 . r 9$ & $r \cdot r$ & $|V . r|$ & الذجموع الكلى لأبعاد \\
\hline
\end{tabular}

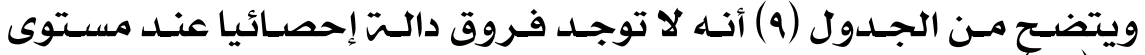

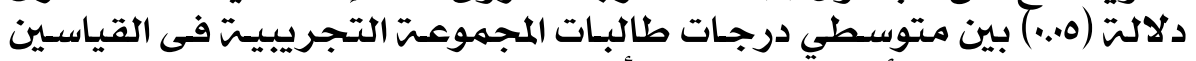

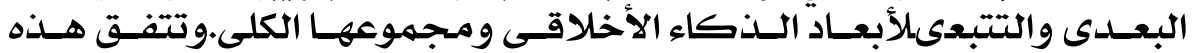

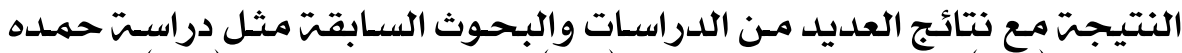

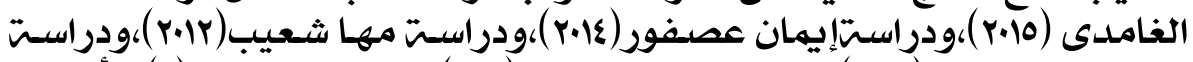

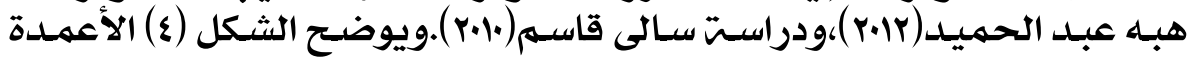

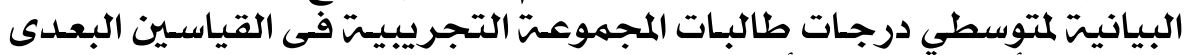

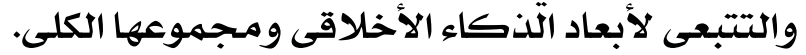

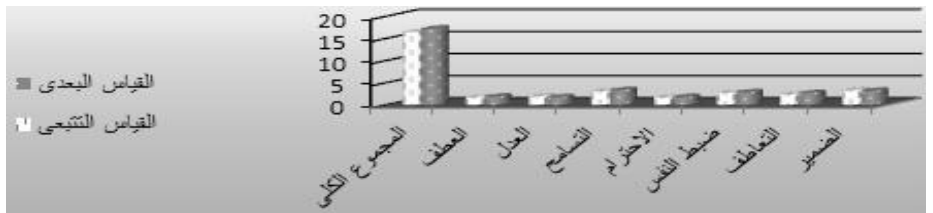

ثكل (ع) الأعملة البيانيت لمتوسطي درجات طالبات المجموعت التجريبيت فى القياسين البعلى والتتبعى

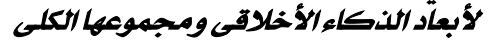

YMI

$\mathrm{Cr}^{2}$ 


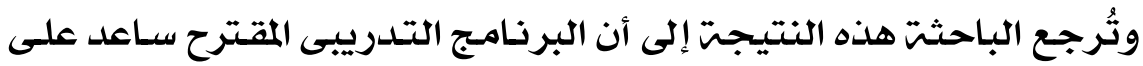

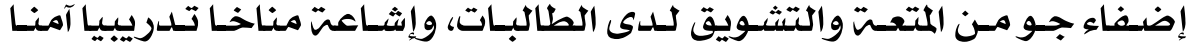

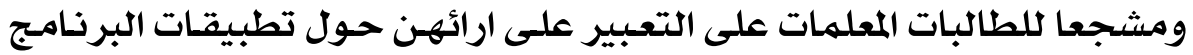

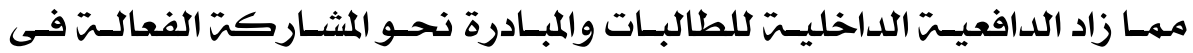

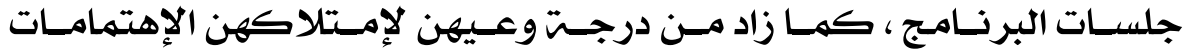

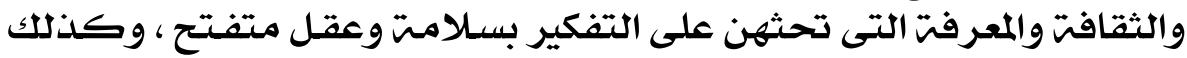

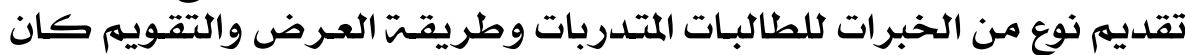

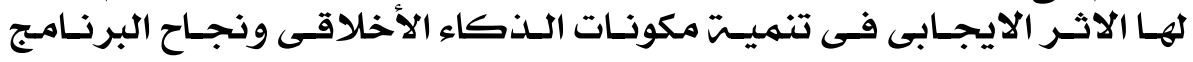
وتحقيق أهدافه .

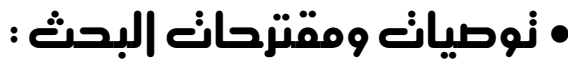

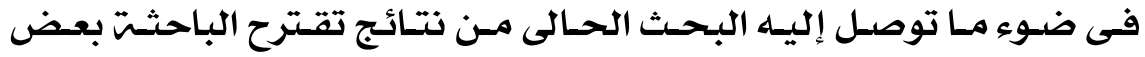
التوصيات والمقترحات التاليت:

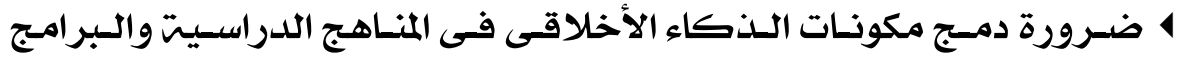

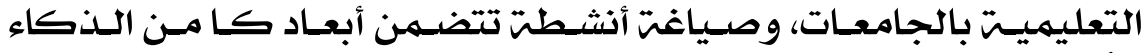

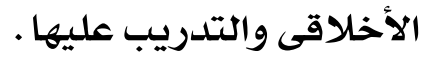

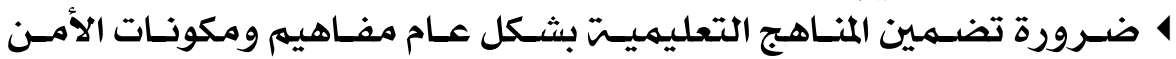

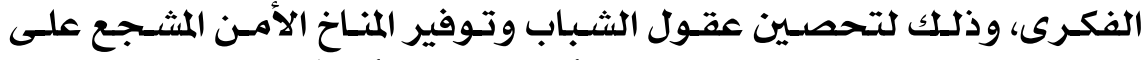

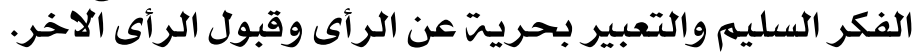

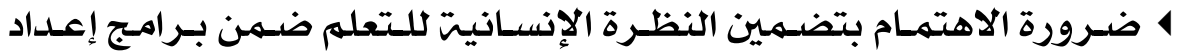

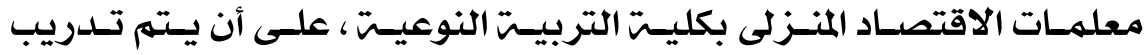

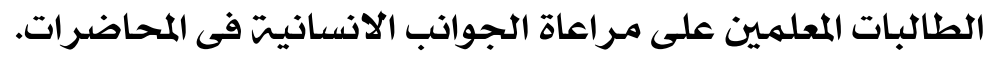

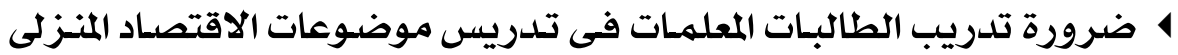

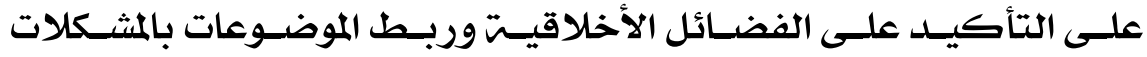

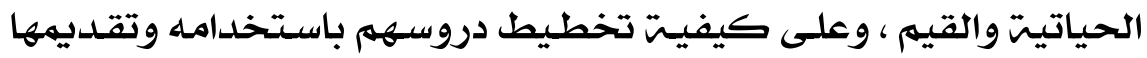

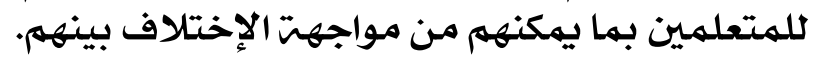

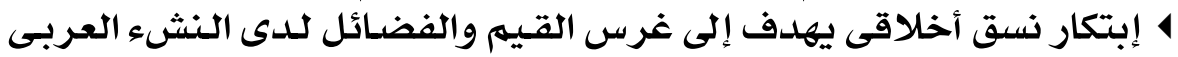
ومعليميههم.

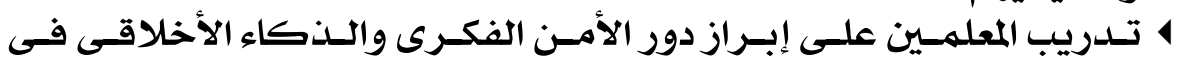

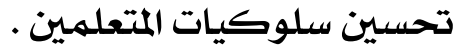
1 تصميهم برامـج إرشاديت وتوعويت لتنميت الأمن الفكرى والذين الذكاء الأخلاقى لدى المتعلهمين.

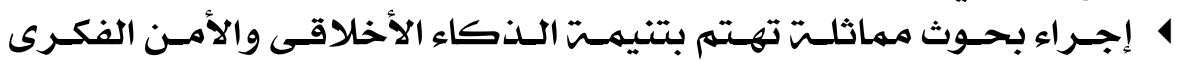

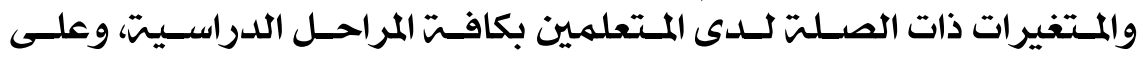
تخصصات مختلفتة. 


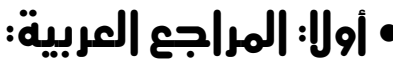

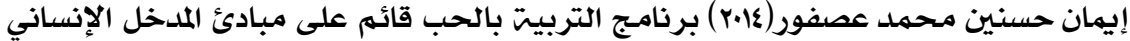

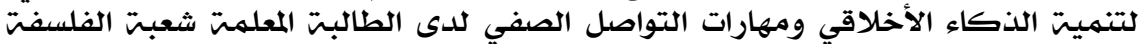

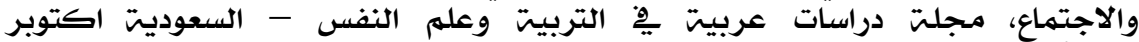

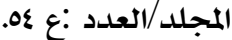

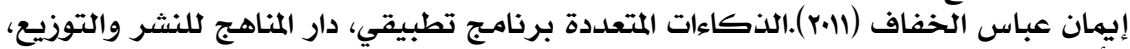

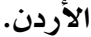
أيهن مزاهرة؛ ليلى نشيوات(.ا.r ). مدخل الى علهم الاقتصاد المنزلى ، دار المناهج للنشر والتوزيع،

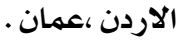

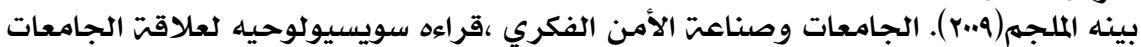

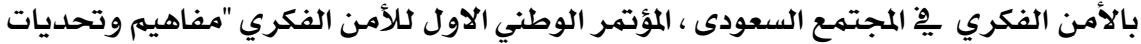

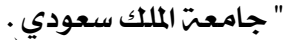

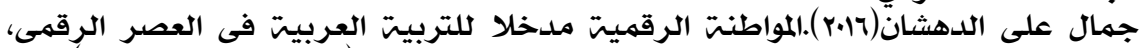

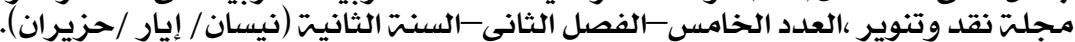

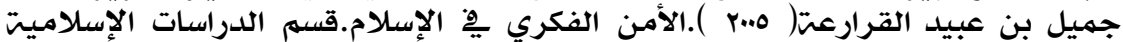

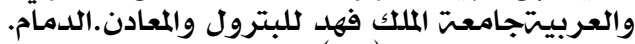

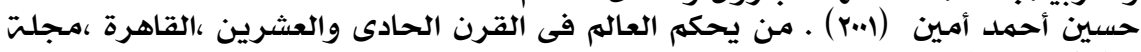
الهالال عدد يناير

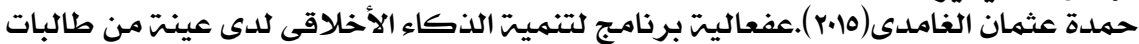

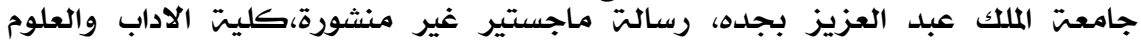
الانسانيت، قسمى علم النفس.

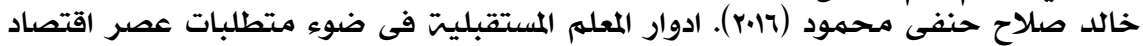

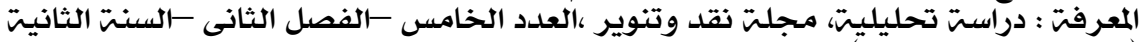

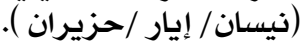

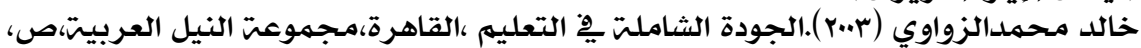
.

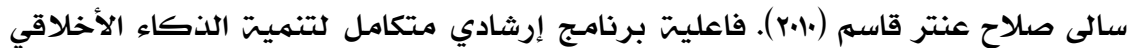

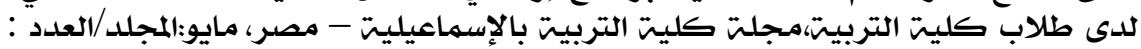
صفاء يوسف الاعصر (1999).برامج التدريب:محكات بناءها وتقييمها،القاهرة، دار قباء

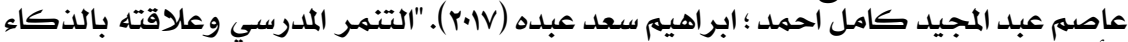

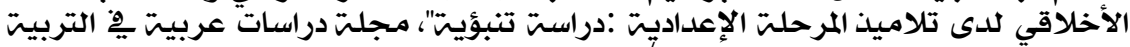

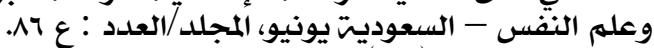

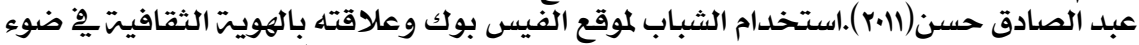

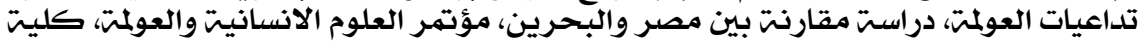

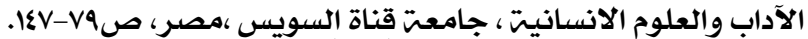

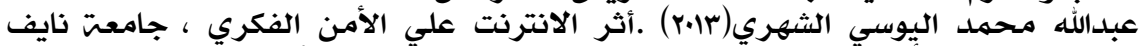

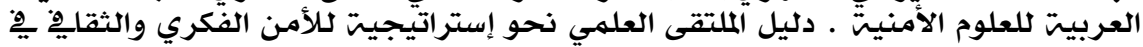

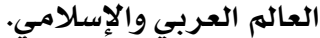

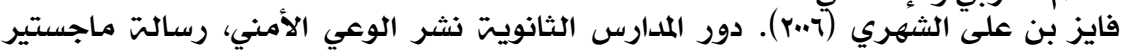

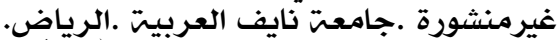

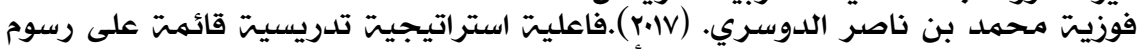

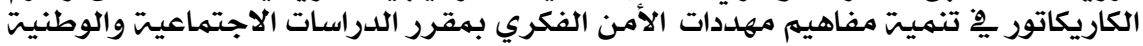

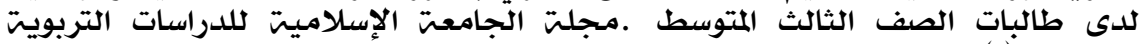




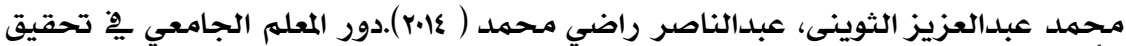

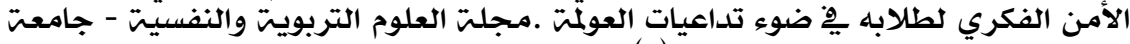

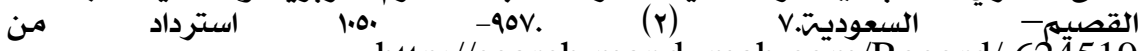
http://search.mandumah.com/Record/ 624519

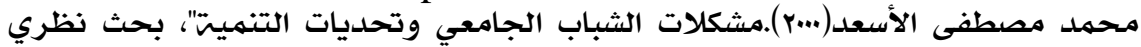

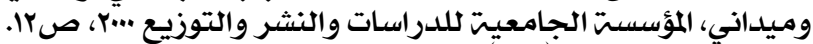

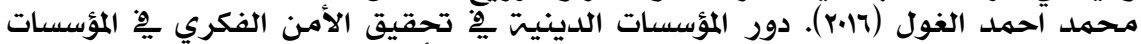

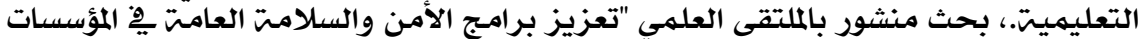

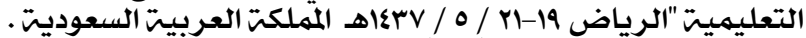

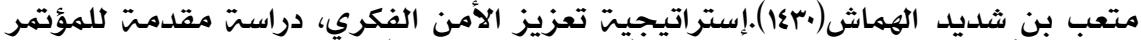

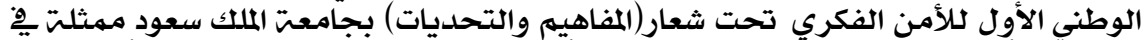

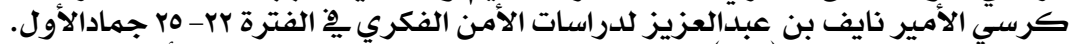

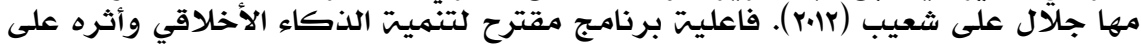

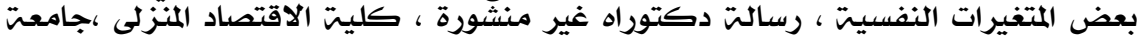
المنوفيتة.

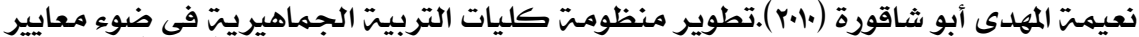

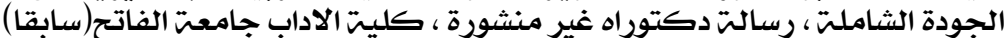

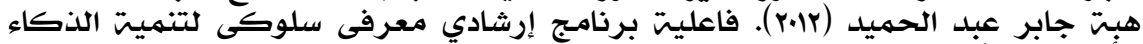

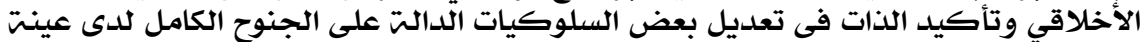

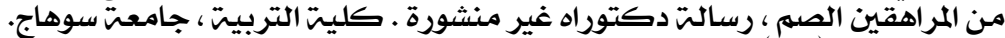

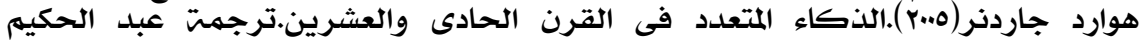

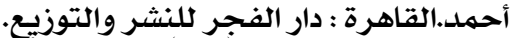

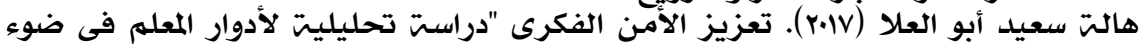

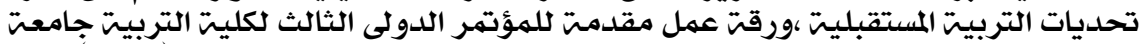

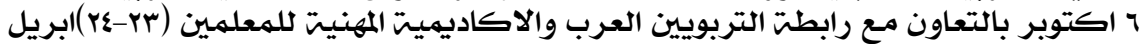
$. r+1 \mathrm{~V}$

\section{ثانيا: المر|جع الجنبية:}

- Borba, M (2000). Parents do make A difference. San Francisco, Jessy - Bass.

- Borba, M (2001). Building Moral Intelligence. Awiley Impaint, Jessey - Bass.

- Borba, M (2002). Building Moral Intelligence, The Seven Virtues That Teach Kids To Do the Right Thing. Awiley Impaint, Jessey - Bass.

- Borba, M. (2003). Tips for building moral intelligence in students, Curriculum Review, 42(7), 23- 30.

- Corder, G; Foreman, D. (2009). Nonparametric statistics for non-statisticians A Step-by-Step Approach. USA. New Jersey: john Wiley \& Sons. Sons, Hoboken.

- Chua, T. \& Crawford, L. (2000). Developing the moral intelligence of children, National Institute of Education, Singapore.

- Gardner, H. (1983). Frames of Mind: The Theory of Emotional Intelligence. New York: Basic Books.

- Koizumi, H. (2017). Scientific Learning and Education for Human Security and Well-Being. In Children and Sustainable Development (pp. 239-257). Springer International Publishing. 
(العرو العانشر

- Pallant, J. (2007). SPSS Survival Manual a Step by Step Guide to Data Analysis using SPSS for Windows, third edition, England: McGraw-Hill Education.

- Pahlavani, F., \& Azizmalayeri, K. (2016). The Relationship between Moral Intelligence with Organizational Development. Human Resource Management, 3(6), 31-38.

- Rahamneh, K. F. A., \& Al- Qudah, M. A. H. (2016). A Proposed Educational Vision for Activating the Role of the Jordanian Universities Students Families in Enhancing Students Intellectual Security from the Students Perspectives. European Scientific Journal, 12(16).

- Rubinstein, R. E. (2017). State Security, Human Security, and the Problem of Complementarily. In Rethinking Security in the Twenty-First Century (pp. 225-243). Palgrave Macmillan US.

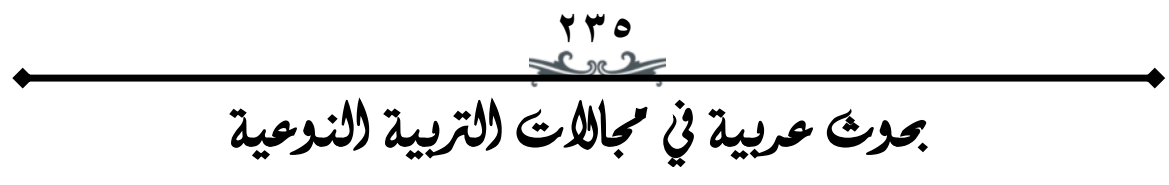

